Saint Louis University School of Law

Scholarship Commons

All Faculty Scholarship

2008

\title{
Life and Death Decisions: Prosecutorial Discretion and Capital Punishment in Missouri
}

Katherine Y. Barnes

University of Arizona Rogers College of Law

David L. Sloss

Santa Clara University - School of Law

Stephen C. Thaman

Saint Louis University School of Law

Follow this and additional works at: https://scholarship.law.slu.edu/faculty

Part of the Criminal Law Commons, and the Criminal Procedure Commons

\section{Recommended Citation}

Barnes, Katherine Y. and Sloss, David L. and Thaman, Stephen C., Life and Death Decisions: Prosecutorial Discretion and Capital Punishment in Missouri (March 16, 2008). Arizona Legal Studies Discussion Paper No. 08-03; 3rd Annual Conference on Empirical Legal Studies Papers.

This Article is brought to you for free and open access by Scholarship Commons. It has been accepted for inclusion in All Faculty Scholarship by an authorized administrator of Scholarship Commons. For more information, please contact erika.cohn@slu.edu, ingah.daviscrawford@slu.edu. 


\title{
AR THE UNIVERSITY \\ A. OF ARIZONA.
}

James E. Rogers College of Law

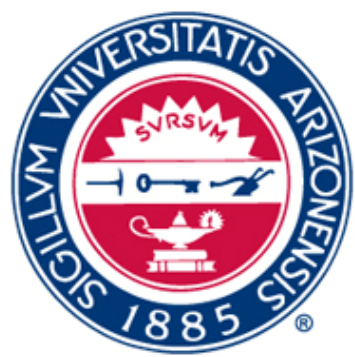

\section{Arizona Legal Studies Discussion Paper No. 08-03}

\section{Life and Death Decisions: Prosecutorial Discretion and Capital Punishment in Missouri}

\author{
Katherine Y. Barnes \\ The University of Arizona \\ James E. Rogers College of Law \\ David Sloss \\ Stephen C. Thaman \\ St. Louis University School of Law
}

March 2008

This paper can be downloaded without charge from the Social Science Research Network electronic library at: http://ssrn.com/abstract=1107456 


\section{Life and Death Decisions \\ Prosecutorial Discretion and Capital Punishment in Missouri \\ Katherine Barnes, David Sloss and Stephen Thaman}

\section{Introduction}

In every criminal justice system, there is a need to strike a balance between conferring too much discretion on decision-makers, and granting them too little discretion. The Federal Sentencing Guidelines have been widely criticized on the grounds that they grant judges too little discretion over sentencing decisions. ${ }^{1}$ Excessively narrow discretion produces one type of arbitrariness: judges are not able to account for individualized factors that are relevant to sentencing. However, a system that confers excessively broad discretion on decision-makers produces a different type of arbitrariness: it yields results that are inconsistent with the fundamental principle that like cases should be treated alike. The Supreme Court's decision in Furman v. Georgia, ${ }^{2}$ which invalidated death penalty statutes throughout the United States, was largely motivated by concerns about this second type of arbitrariness. The primary reason the death penalty was ruled unconstitutional in Furman was that statutes gave too much discretion to prosecutors and jurors to decide which murders should be punished by death, resulting in an arbitrary system where only a small minority of those eligible for death actually receive the penalty. ${ }^{3}$ The results were that African-Americans and other poor and minority defendants were disproportionately likely to be sentenced to death. ${ }^{4}$

This article analyzes capital punishment in Missouri in an effort to assess whether Missouri's death penalty statute accords prosecutors such broad discretion that the practical implementation of the statute raises the types of arbitrariness concerns at issue in Furman. To conduct the analysis, the authors created a database of 1046 homicide cases prosecuted in Missouri over a five year period (the "large database"). The large database includes substantially all of the homicide cases in Missouri that satisfy the following criteria: (1) the case was initially charged as first-degree murder (M1), second-

\footnotetext{
$1 \quad$ See, e.g., Kate Stith \& Jose A. Cabranes, To Fear Judging No More: Recommendations for the Federal Sentencing Guidelines, 11 FED. SENTENCING REP. 187-188 (1999).

408 U.S. 238 (1972).

Id. at 293 (Brennan, J., concurring) ("When the punishment of death is inflicted in a trivial number of the cases in which it is legally available, the conclusion is virtually inescapable that it is being inflicted arbitrarily. Indeed, it smacks of little more than a lottery system.").
}

$4 \quad$ Id. at 249-51 (Douglas, J., concurring). 
degree murder (M2), or voluntary manslaughter (VM); (2) the initial indictment or information was dated between Jan. 1, 1997 and Dec. 31, 2001; and (3) the defendant was ultimately convicted of a homicide offense. ${ }^{5}$ The authors also created a "small sample" of 247 cases selected from the large database that we studied in greater detail. ${ }^{6}$ We gathered substantial information about cases in the small sample, and used this information to investigate the decision-making process in more depth, with a particular focus on disparate racial impact and geographic disparities.

In certain respects, this article is similar to other studies that have analyzed the implementation of capital punishment in particular states. ${ }^{7}$ However, several features of this study distinguish it from prior studies. First, whereas several previous studies have focused narrowly on cases charged as M1, our large database includes cases charged as M2 and VM. Within this broader universe, we screened cases to determine whether they were death-eligible. In this respect, our strategy is similar to two recent studies in Nebraska and Maryland that examined a broad range of homicide convictions and then narrowed the class by screening cases. ${ }^{8}$ Although cases that yield M2 or VM convictions are not death eligible, prosecutors have broad discretion in choosing whether to charge a case initially as M1, M2 or VM. Therefore, a study designed to discern the effects of prosecutorial discretion on capital punishment would be seriously flawed if the database omitted cases charged as M2 or VM.

The second point is closely related to the first. By gathering data on all cases charged as M1, M2 or VM, we are able to provide a rough measure of how much "work" the statute does in selecting capital cases from the broader universe of intentional homicide cases, and how much of that "work" is left to prosecutorial discretion. The results are illuminating. We estimate that at least 76 percent of the cases in the large database are death-eligible under the statute; ${ }^{9}$ the other 24 percent are not death eligible.

\footnotetext{
$5 \quad$ For a more precise description of the parameters for including cases in the large database, see infra Part IV.

$6 \quad$ See infra Part IV (describing the selection of the small sample).

See infra Part II (providing a survey of existing literature in this area).

See David C. Baldus et al., Arbitrariness and Discrimination in the Administration of the Death Penalty: A Legal and Empirical Analysis of the Nebraska Experience, 81 Nebraska L. Rev. 486 (2002) [hereinafter, "Nebraska Study"]; Raymond Paternoster et al., An Empirical Analysis of Maryland's Death Sentencing System with Respect to the Influence of Race and Legal Jurisdiction), available at http://www.newsdesk.umd.edu/pdf/finalrep.pdf. [hereinafter, "Maryland Study"].

See infra Part V (explaining how this estimate is derived).
} 
Only 2.5 percent of the cases yielded death verdicts. In another 2.5 percent of the cases, juries or trial judges rejected a capital charge presented by a prosecutor. Thus, death eligible cases in which prosecutors chose not to pursue capital charges comprise at least 71 percent of the cases in the large database. Therefore, in rough terms, prosecutors are doing three times as much "work" as the statute in deciding which cases merit capital punishment, because the statute eliminated only 24 percent of the cases from the class of death-eligible offenses, whereas prosecutors eliminated 71 percent by electing not to pursue capital charges. These figures suggest that the Missouri legislature has largely abdicated its responsibility to establish statutory limits on capital punishment and delegated that legislative function to individual prosecutors.

A third distinguishing feature of this study relates to the fact that Missouri is the subject of the study. Most recent empirical studies of capital punishment in specific states have focused on states, such as Nebraska and Maryland, that have executed very few people. ${ }^{10}$ In contrast, Missouri is one of the nation's leading death penalty states. Having executed 66 prisoners since the death penalty was reinstated, Missouri ranks fourth in the country in the total number of executions since 1976, behind Texas, Virginia and Oklahoma, and just ahead of Florida. ${ }^{11}$ Missouri ranks fifth in per capita terms, behind Oklahoma, Texas, Delaware and Virginia. ${ }^{12}$ Ours is the only recent study, except for an ABA-sponsored study of Florida, ${ }^{13}$ that provides a detailed empirical analysis of capital punishment in one of the "top five" death penalty states.

The fourth distinguishing feature of this study is the empirical investigation of disparities in the rates at which different prosecutors pursue M1 charges versus lesser homicide charges. We know of no other study that investigates this issue, although many

$10 \quad$ Maryland has executed only five people since 1976. Nebraska has executed three people. See http://www.deathpenaltyinfo.org/article.php?scid=8\&did=1110.

11 Texas is in first place with 382 executions, followed by Virginia with 98 and Oklahoma with 84. Trailing closely behind Missouri are Florida with 64 executions, North Carolina with 43 and Georgia with 39. http://www.deathpenaltyinfo.org/state/.

12 After rounding off the July 2006 populations of the states in millions to one decimal point, Missouri executed 11.4 per million population since 1976. Oklahoma led with 23.3 per million, followed by Texas with 16.3, Delaware with 15.5 and Virginia with 12.9. Census data from,http://factfinder.census.gov/servlet/GCTTable?_bm=y

$\&$-geo_id $=01000 U S \&$-_box_head_nbr=GCT-T1\&-ds_name=PEP_2006_EST\&-_lang=en\&-redoLog=false \&-format=US-9\&-mt_name=PEP_2006_EST_GCTT1R_US9S\&-_sse=on.

13 See American Bar Association, Evaluating Fairness and Accuracy in State Death Penalty Systems:

The Florida Death Penalty Assessment Report (2006), available at http://www.abanet.org/moratorium/assessmentproject/florida.html. [hereinafter, "Florida Study"]. 
studies have investigated death sentencing. Because there are many more M1 convictions than death sentences, and because M1 convictions are punished much more harshly than M2 convictions, disparities between M1 and lesser convictions have significant practical implications.

One other distinguishing feature relates to the interplay between race and geography. Other studies that have examined geographic disparities in the implementation of capital punishment in particular states have tended to divide counties within the state between rural and urban. ${ }^{14}$ We use the urban/rural divide, but we also divide counties according to the racial composition of the jury pool in different counties. One of this study's more interesting findings is that there is a statistically significant correlation between jury decision-making in capital trials and the demographics of the jury pool.

This study examines both geographic and racial disparities in the implementation of capital punishment in Missouri. We examine these disparities in two different decision processes: the M1 conviction process and the death sentence process. Each of these decisions is further broken down into three critical decision-making points. For the M1 conviction process, these are: 1) The decision whether to charge M1 versus a lesser homicide charge; (2) the decision whether to go to trial on an M1 charge; and (3) the factfinder's decision whether to convict the defendant on the M1 charge. For the death penalty decision process, the three stages are: 1) the decision whether to seek the death penalty; 2) the subsequent decision whether to accept a plea agreement or take the capital charge to trial; and 3) the final decision whether to impose a death sentence. The geographic analysis focuses on disparities across counties in the way these decisions are made. The racial analysis focuses on disparities based on race of defendant and race of victim. These analyses do not adjust for the culpability of the individual, or the heinousness of the crime. Instead, the project provides a description of the disparities created across important fault lines by the decisions made by prosecutors, factfinders and defendants, whether justified by outside factors or not. ${ }^{15}$

\footnotetext{
$14 \quad$ See, e.g., Nebraska study, supra note 8.

15 In future work, we plan to measure the culpability of the defendant and the heinousness of the crime, in order to control for these factors and investigate any potential causal connections between geography and race and the decision-making processes for M1 convictions and death sentences.
} 
The key findings related to racial disparities are as follows. First, we found no significant race-based effects in the decision to charge M1 rather than a lesser-included homicide offense, or in the final M1 conviction rate. There were significant disparities, however, in the decision to take an M1 charge to trial, across both race-of-defendant and race-of-victim. Black defendants are less likely to face an M1 trial than white defendants, although their overall M1 conviction rate is similar. Stated differently, black defendants are more likely to accept an M1 guilty plea, whereas white defendants are more likely to be convicted of M1 after a trial, but these two avenues lead to similar M1 conviction rates. Second, we found significant and persistent racial disparities in the capital sentencing decision process. Black defendants were less likely to face a capital charge, but more likely, once charged, to face a capital trial than white defendants. Overall, black defendants were less likely to be sentenced to death, although the sentencing rates depended significantly on the race of the victim as well, with defendants who kill white victims sentenced to death more often than those who kill black victims.

The data show that prosecutorial decisions vary widely across counties. Indeed, the variation begins with the decision whether to charge a homicide case as M1 or M2. For example, St. Louis City and Jackson County (Kansas City) are the two largest jurisdictions in Missouri in terms of the number of homicide prosecutions. Prosecutors in St. Louis City charged M1 in 85.4 percent of their cases. In contrast, prosecutors in Jackson County charged M1 in only 28.3 percent of their cases. Because cases charged as M2 are not eligible for capital punishment, Jackson County prosecutors eliminated more than seventy percent of their cases from the class of death-eligible offenses by charging the cases as M2 instead of M1 ${ }^{16}$ In contrast, the initial charging decisions of St. Louis City prosecutors left the death penalty "on the table" in more than 85 percent of their cases. As the subsequent analysis demonstrates, there are significant variations across counties in all stages of the decision-making process. These geographic disparities mean that a homicide defendant in one county is more likely to receive a death sentence than a homicide defendant in another county.

16 This assumes that most cases that were charged as M2 satisfy the statutory requirements for an M1 charge. For a defense of this proposition, see infra notes _ and accompanying text. 
The analysis in this article provides a statistical snapshot of homicide cases in Missouri, focusing on how the discretionary decisions of prosecutors correlate with racial and geographic disparities along the divide between M1 and lesser homicide offenses, and along the divide between death sentences and lesser sentences. It bears emphasis, though, that the analysis does not support any conclusions about causal relationships between prosecutorial decisions and geographic/racial disparities. Investigation of causal relationships between prosecutorial decisions and different outcomes requires the introduction of control variables; that will be the focus of a subsequent study

The remainder of this article is divided into seven parts. Part II provides a brief survey of scholarly literature involving empirical analysis of homicide cases in other states, with a particular focus on studies of capital punishment. Part III provides a brief overview of the relevant law and practice in Missouri, focusing on the ways in which Missouri law broadens the scope of prosecutorial discretion. Part IV discusses our methodology and research design. Part $\mathrm{V}$ presents a rough quantitative measurement of the scope of prosecutorial discretion. Part VI analyzes both racial and geographic disparities across the M1 versus M2 dividing line. Part VII investigates the implementation of the death penalty in Missouri, focusing on geographic and racial disparities in charging and sentencing outcomes. Part VIII presents conclusions and policy recommendations.

II.

\section{Literature Review}

Much modern empirical research on the death penalty focuses on discretionary choices made by prosecutors and juries that influence the application of the death penalty. Our study is no exception: we focus on the decisions that Missouri prosecutors make in charging and plea bargaining, and how other actors in the system curtail the discretion that prosecutors exercise. The goal, as with other studies, is to determine how the death penalty is applied, with particular attention to racial disparities and "arbitrariness", which is generally defined as unexplained differences or differences explained only by geography or other unacceptable factors. Since the landmark study by David Baldus and co-authors on the Georgia death penalty, ${ }^{17}$ there have been many excellent articles

17 David C. Baldus, et Al., Equal Justice And the Death Penalty (1990). 
describing the interplay between prosecutorial discretion and the death penalty in several states. $^{18}$ Overall, these studies find that race impacts the decision-making process, particularly the initial decision to seek the death penalty. The most robust finding across all death penalty studies is that individuals who kill white victims are more likely to receive the death penalty. ${ }^{19}$ Studies that investigate geographic differences also find that location matters; these studies usually investigate urban centers versus more rural areas, and find that decision-making is different across these different locations. Two recent studies of the Nebraska and the Philadelphia death penalty systems, both also performed by a team of researchers led by Baldus, provide an excellent, detailed summary of the research through $2002 .^{20}$ We need not replicate that discussion here. Instead, we highlight some commonalities between the prior research and our own, as well as the differences in our approach, and discuss some of the more recent research.

The Nebraska study, investigating an entire state system, is most similar to our own. In that study, researchers investigated several decision-making points: the decision to charge a death-eligible crime; the decision to seek the death penalty at some point in the pretrial process; the decision to proceed to a capital trial on guilt; the decision to proceed to a penalty trial after the defendant is found guilty of a death-eligible crime, and, finally, the jury's decision to impose death. These are the five critical decisionmaking points in the process that ultimately leads to a death sentence. Using a dataset of all death-eligible crimes, the Nebraska study found no evidence that race impacts the decision-making process in Nebraska. ${ }^{21}$ It did find, however, significant geographic effects, with large differences between the urban centers in Nebraska and the rural areas.

18

Several ABA-sponsored studies have studied the entire death penalty practice in particular states. To date, researchers in Alabama, Arizona, Florida, Georgia, Indiana, Ohio, Pennsylvania, and Tennessee have published studies regarding their state's death penalty practices as a part of the ABA Death Penalty Moratoriam Implementation Project.. See http://www.abanet.org/moratorium/home.html. These studies all focus on the same basic questions, investigating the entire death penalty process, from charging practices through execution itself, and include all the potential actors in the system: prosecutors, defense attorneys, judges, juries, legislatures and the governor. These studies are particularly valuable in their comprehensive research on the entire system, from filing a notice to seek the death penalty to any potential pardon, and finally to an execution.

19 Still, this finding does not appear in all states, or all time periods. See Nebraska Study, supra note 8 , at 499-502.

20 See Nebraska Study, supra note 8, at 499-502; David C. Baldus et al., Racial Discrimination and the Death Penalty in the Post-Furman Era: An Empirical and Legal Overview with Recent Findings from Philadelphia, 83 Cornell L. Rev. 1638, 1658-60 (1998).

$21 \quad$ Nebraska Study, supra note 8, at 
In Nebraska, the urban centers treat all crimes more harshly. ${ }^{22}$ Because these two locations have different demographics, the study did find evidence of an adverse disparate impact on minority defendants due to the location of their crimes. ${ }^{23}$ The study used similar methodology to ours, screening a large number of homicide cases to determine death eligibility, and then coding a large amount of information about each death eligible case.

In addition, a 2002 Maryland study, performed by Raymond Paternoster and coauthors, found that defendants who killed white victims were more likely to face a capital trial and more likely to be sentenced to death. ${ }^{24}$ The study also found significant geographic disparities across counties. Both of these findings, however, should be tempered by the fact that the study controls for culpability only by including the number of statutory aggravators in a case. ${ }^{25}$

Both the Nebraska study and the Maryland study had the advantage of being state-sponsored. Because the present study was not state-sponsored, we confronted certain obstacles in data collection, which led to significant gaps in data collection for some cases. ${ }^{26}$ We rely on estimates based on a detailed analysis of a stratified random sub-sample of cases to fill in the gaps. In contrast, the authors of the Nebraska and Maryland studies were able to obtain fairly complete information about each case. This leads to more precise estimates ${ }^{27}$ of the disparities in death penalty application. The information gaps in the present study primarily impact the first two steps in the decisionmaking process (charging M1 and seeking death), because all cases charged as capital cases are included in our sub-sample. These two data problems - lack of data (because of

\footnotetext{
$22 \quad$ Id. at

23 The interplay of geographic differences in charging practice and racial patterns of violence is important. Do urban centers treat crimes more harshly because of location, or because of the race of those who commit the crimes?

$24 \quad$ Maryland Study, supra note 8, at .

25 The number of statutory aggravators is not an especially good measure of culpability because there tends to be a great deal of overlap among statutory aggravators, especially in states with a large number of aggravators. Thus, the number of statutory aggravators in a case may say as much about the drafting of the statute and the prosecutor's charging decisions as it does about the culpability of the individual defendant. $26 \quad$ See infra notes _ and accompanying text.

27 Some would say that measures based on complete information are not estimates at all, but a perfect description of the universe of death penalty cases in the state in question. We do not engage in this philosophical debate over the appropriate nomenclature for study of a population; we only point out that the results we present in Part VII are, in fact, estimates based upon a sample of cases.
} 
the small number of capital homicides) and the expense of obtaining the data available are present to some extent in all death penalty studies.

Beyond data constraints, there are four key methodological issues that studies of this nature must address: (1) determining the population of cases to be investigated; (2) defining which cases are "death eligible"; (3) deciding what source(s) of data to utilize; and (4) developing measures to control for crime-specific characteristics, where appropriate, that properly inform the charging and sentencing decisions. With respect to the first point, for the reasons specified above, ${ }^{28}$ the present study investigates a population of cases that includes substantially all of the intentional homicide cases prosecuted in Missouri over a five year period. Recent comprehensive studies have adopted a similar approach, although some studies focus only on cases charged as capital cases. $^{29}$

Secondly, this study uses a probable cause standard to determine which cases are death-eligible. ${ }^{30}$ Prior studies generally use a more conservative standard for assessing death eligibility. For example, the Maryland study requires "clear evidence" that the crime satisfies all the statutory requirements for capital punishment. ${ }^{31}$ We use the lower "probable cause" standard because that is the only legal requirement necessary to indict for first degree murder and to seek the death penalty. Although prosecutors must prove the case beyond a reasonable doubt to the jury, most cases end in plea bargaining.

Thirdly, this study uses a variety of data sources to investigate cases in the small sample, including police investigative reports, FBI records of criminal histories, court records, newspaper articles and appellate decisions. The goal is to recreate as closely as possible the data available to the prosecutor at the time the prosecutor makes initial charging and plea bargaining decisions. Other studies gather facts from pre-sentencing reports and trial transcripts. We chose not to use trial transcripts because most of the

\footnotetext{
28 See supra notes _ and accompanying text.

29 See, e.g., ABA Death Penalty Moratorium Project, supra note 18

30 Specifically, a crime initially charged as M2 or VM is "M1-eligible" if a prosecutor could make a good faith, reasonable argument that the statutory requirements for M1 are satisfied. Additionally, all crimes charged as M1 are deemed M1-eligible. An M1-eligible crime in which the prosecution did not seek death is "death-eligible" if the prosecution could make a good faith, reasonable argument that one or more statutory aggravating factors is present. Additionally, all cases charged as capital crimes are deemed death-eligible.

$31 \quad$ See Maryland Study, supra note 8, at
} 
cases we investigated were resolved by plea agreements. Pre-sentencing reports have advantages when focusing solely on the decision whether to sentence an individual to death, because they provide more balanced information about mitigating and aggravating factors, similar to what would be presented in a penalty trial. But prosecutors in Missouri often do not have this information when making pre-trial decisions. Hence, the information would not explain any of the charging and plea bargaining decisions made before trial, which are a central focus of this study. Due to the decision not to use presentencing reports, we are missing information about mitigating factors in some cases that would be useful in controlling for culpability.

The final methodological difference between this study and prior studies relates to whether to control for culpability. Our study does not focus on the causal link between race or geography and capital punishment. Thus, there is no need to control for culpability. Instead, we focus on the racial and geographic disparities associated with prosecutorial decision making. These disparities may be justified by other factors, but they exist nonetheless, and inform our judgment of how the criminal justice system works. As noted above, we plan to do a follow-on study that will control for culpability and examine causal relationships between prosecutorial decision-making and racial and geographic disparities.

\section{III.}

\section{Law and Practice in Missouri}

Part III briefly summarizes Missouri law governing the implementation of capital punishment, providing comparisons to other key death penalty states to give the reader an impression of the ways in which Missouri is both typical and atypical. The discussion focuses on the ways in which Missouri law both narrows and broadens the scope of prosecutorial discretion in comparison to other states.

\section{A. Classification of Homicide as Murder}

There are 39 death penalty jurisdictions in the United States, including 38 states and the federal government. Twenty-four of those 39 jurisdictions separate murder into 
two degrees. ${ }^{32}$ In contrast, fifteen of those jurisdictions have only one degree of murder. ${ }^{33}$ Missouri, like most states, divides murder into first degree and second degree murder.

Under Missouri law, "a person commits the crime of murder in the first degree if he knowingly causes the death of another person after deliberation upon the matter."34 There are only two permissible punishments for first degree murder in Missouri: the death penalty, or life imprisonment without eligibility for probation or parole (LWOP). ${ }^{35}$ The crime of second degree murder includes both felony murder and homicides where the perpetrator acted "with the purpose of causing serious physical injury to another person." 36 Additionally, any homicide where the defendant "knowingly causes the death of another person" qualifies as second degree murder. ${ }^{37}$ The punishment for second degree murder is much lighter than it is for first degree murder. Second degree murder is punishable as a Class A felony ${ }^{38}$ by 10-30 years imprisonment, or by life imprisonment with eligibility for parole. ${ }^{39}$

The statutory definition of murder in Missouri narrows the class of death-eligible offenses in two significant respects. First, most states classify some forms of reckless homicide as murder, thereby making at least some reckless homicides death-eligible. In contrast, Missouri classifies all reckless homicides as manslaughter, not murder. ${ }^{40}$ Because manslaughter is not a death-eligible crime, the legislative decision to classify all

\footnotetext{
32 Jurisdictions that divide murder into two degrees are: Arizona, Arkansas, California, Colorado, Delaware, Florida, Idaho, Kansas, Maryland, Missouri, Nebraska, Nevada, New Hampshire, New Mexico, North Carolina, Ohio, Oklahoma, Pennsylvania, South Dakota, Tennessee, Virginia, Washington, Wyoming and the Federal System.

33 Jurisdictions with one degree of murder are: Alabama, Connecticut, Georgia, Illinois, Indiana, Kentucky, Louisiana, Mississippi, Montana, New Jersey, New York, Oregon, South Carolina, Texas, and Utah.

$34 \quad$ V.A.M.S. $\S 565.020$.

V.A.M.S. ' $565.020(2)$.

V.A.M.S. $\S 565.021$.

Id.

V.A.M.S. ' $565.021(2)$.

V.A.M.S. ' $558.011(1)(1)$.

See V.A.M.S. § 565.024. In addition to Missouri, there are nine other death penalty states that classify reckless homicide as manslaughter, not murder. See Ala.Code 1975' 13A-6-2(a)(1); Conn.Gen..Stats,.Ann. ' 53a-54a; Ga. Code Ann., ' 16-5-1; Ind. Code 35-42-1-1(1)(1); Ky. Rev. Stats. ' 507.020(1); La. Stat. Ann.-R.S. 14:30(1); Mont. Code Ann. 45-5-102(1); N.J.Stats..Ann.. 2C:11-3(a); Or.Rev..Stats. ' 163.115(1)(a).
} 
reckless homicides as manslaughter narrows the class of death-eligible offenses, and thereby narrows the scope of prosecutorial discretion.

Second, most states that divide murder into degrees classify felony murder as first-degree murder, ${ }^{41}$ thereby making at least some felony murders death-eligible (even if the defendant did not intend to kill the victim). ${ }^{42}$ Missouri, however, classifies felony murder as second-degree, not first degree murder. ${ }^{43}$ Consequently, felony murder is not death eligible in Missouri unless the prosecutor can prove that the defendant killed the victim "knowingly . . . after deliberation upon the matter." 44 The legislative decision to classify felony murder as second degree murder also narrows the class of death-eligible offenses, and narrows the scope of prosecutorial discretion.

Whereas Missouri's legislative classification of felony murder and reckless homicide narrows the class of death-eligible offenses, Missouri's definition of "deliberation" broadens the class of death-eligible offenses. Among the death penalty states with two degrees of murder, there is a split between those that require serious reflection before an intentional murder will be raised to first degree murder, ${ }^{45}$ and those

41 See, e.g., Ariz. Rev..Stats.. ' 13-1105(2); Cal Penal Code ' 189; Colo. Rev. .Stats. .Ann.. ' 18-3-102(1)(a); West's Fla Stats..Ann. ' 782.04 (1)(a)(2); Idaho Code. ' 18-4003 (d); Kan. Stats. ' 21-3401(1)(b); Md. Code, Criminal Law, ' 2-201(A)(4); Neb.Rev.St. ' 28-303A(2); Nev. Rev. Stats. 200.030(1)(b); N. M. Stats. Ann. 1978, ' 30-2-1(A) (2); N.C.Gen. Stats. Ann. ' 14-17; 21 Okl. Stats. Ann.' 701.7 (B); SD Crim Laws ' 22-16-4 (2); Tenn. Code Ann. ' 39-13-202 (a)(2); Va. Code Ann. ' 18.2-32; West's Rev. Codes Wash. Ann. 9A.32.030(1)(c); Wyo. Stats. 1977 ' 6-2-101 (a); 18 U.S.C. ' 1111. In addition to Missouri, at least three other death penalty states categorize felony murder as second-degree murder. See 11 Del.Code. ' 635 (2); La. Stats. Ann-R.S. 14:30.1(2)(a); 8 Pa.Cons. Stats. Ann. ' 2502(b).

42 Historically, any death ensuing from the commission of one of the "big five" crimes (robbery, burglary, rape, arson and kidnapping) was automatically first degree, capital murder, without more. The majority of capital jurisdictions still recognize deaths during the commission of the "big five" crimes as potentially capital murder, whether they have one or two degrees of murder. However, for defendants convicted of murder on a felony murder theory, the Eighth Amendment restricts application of the death penalty to: a) individuals who killed or intended to kill,; or b) individuals who were a major participant in the crime and manifested extreme recklessness. See Tison v. Arizona, 481 U.S. 137 (1987); Enmund v. Florida, 458 U.S. 782 (1982).

$43 \quad$ V.A.M.S. ' 565.021(1)(2) provides for second-degree murder "when another person is killed as a result of the perpetration or attempted perpetration" of any felony or the flight therefrom.

$44 \quad$ V.A.M.S. $\$ 565.020$.

45 Ariz. Rev. Stats. ' 13-1105(A)(1), State v. Thompson, 65 P.3d 420, 424 (Ariz. 2003); Cal. Penal Code ' 189, People v. Anderson, 447 P.2d 942, 945 (Cal. 1968).; Colo. Rev. Stats. Ann. ' 18-3-102(1)(a), Key v. People, 715 P.2d 319, 321 (Colo. 1986).; West's Fla. Stats. Ann. ' 782.04(1)(a)(1), Dupree v. State, 615 So.2d 713, 715 (Fla. App.1993); Idaho Code " 18-4001- 18-4003, State v. Sheahan, 77 P.3d 956,970 (Idaho 2003); Kan. Stats. ' 21-3401(1), State v. White, 950 P.2d 1316, 1325 (Kan. 1997); MD Code, Criminal Law, ' 2-201(A), Bryant v. State, 900 A.2d 227, 238-39 (Md. 2006); Neb.Rev.St. ' 28-303A, State v. Batiste, 437 N.W.2d 125, 132 (Neb. 1989); Ohio Revised Code, ' 2903.01: Tenn. Code Ann. ' 39-13-202 (d); West's Rev. Code Wash. Ann. § 9A.32.030(1)(a), 32.020(1)(a); Wyo. Stats. 1977 ' 6-2-101 (a), Bouwkamp v. State, 833 P.2d 486, 493 (Wyo. 1992); N. M. Stats. Ann. 1978, ' 30-2-1(A), State v. Lucero, 
which hold that "premeditation," and/or "deliberation" may take place immediately before or simultaneous with the formation of the intent to kill, i.e., in a "twinkling of an eye". ${ }^{46}$ Missouri is a "twinkling of an eye" state. "Deliberation" is the key criterion in the Missouri statute that separates first-degree murder from "knowing" second degree murder. ${ }^{47}$ "Deliberation" is defined as "cool reflection for any length of time no matter how brief." 48 As the following analysis demonstrates, under Missouri case law the "deliberation" requirement is satisfied in almost every case involving "knowing" second degree murder. Thus, the only real difference between first degree murder and "knowing" second degree murder is the severity of the punishment.

Under Missouri case law, evidence of "deliberation" is usually deduced from the circumstantial evidence of a culprit's actions. ${ }^{49}$ It is sufficient "deliberation" if the intent to kill is formulated before the lethal blow is struck. ${ }^{50}$ There need not be any "brooding" over the act for an appreciable time before the defendant commences the fatal attack. ${ }^{51}$ Missouri courts have consistently held that "deliberation" may be found if the intent to kill develops, in cases involving firearms, as the trigger is being pulled. In stabbings and other cases, deliberation may be based on the fact that the defendant had to approach the victim before attacking. ${ }^{52}$ The fact that the defendant armed himself with a deadly

541 P.2d 430, 432 (N.M. 1975); N.C.Gen. Stats. Ann. ' 14-17: State v. Myers, 305 S.E.2d 506, 509 (N.C. 1983).

46 For other "twinkling of an eye" states, see, e.g., 8 Pa.Cons. Stats. Ann.. ' 2502(a), Commonwealth v. Carrol, 194 A.2d 911, 916 (Pa. 1963); SDCrim. Law ' 22-16-5; Nev. Rev. Stats. 200.030(1), Schoels v. State, 966 P.2d 735, 738 (1998); Va. Code Ann. ' 18.2-32, Weeks v. Commonwealth, 450 S.E.2d 379, 390 (Va. 1994).

$47 \quad$ Missouri classifies a homicide as first degree murder if a defendant "knowingly causes the death of another person after deliberation upon the matter." V.A.M.S. § 565.020. A defendant who knowingly causes the death of another person without "deliberation" is guilty of second degree murder. V.A.M.S. $\S$ 565.021 .

$48 \quad$ V.A.M.S. $\S 565.002(3)$.

49 The Missouri Supreme Court has held that repeated listening to a rap song which glorified killing could be introduced as circumstantial evidence of "deliberation." State v. Tisius, 92 S.W.3d 751, 781 (Mo. 2002).

50 The Missouri Supreme Court has stated that "in order to convict [a defendant of first degree murder], there must be some evidence that defendant made a decision to kill the victims prior to the murder" as long as the defendant "coolly deliberated on the deaths for some amount of time, however short." State v. Gray, 887 S.W.2d 369, 376-77 (Mo. 1994).

$51 \quad$ State v. Feltrop, 803 S.W.2d 1, 11 (Mo.1991).

52 State v. Clemons, 753 S.W.2d 901, 906 (Mo. 1988) (taking "a few steps" towards the victim is sufficient). 
weapon before a confrontation has often been sufficient evidence of "deliberation.",53 Drawing one's weapon can be sufficient evidence of "deliberation."54 Other instantaneous means of preparation for the deadly assault may be deemed sufficient. ${ }^{55}$ First-degree murder convictions are typically upheld in cases involving "a prolonged struggle, multiple wounds, or repeated blows." 56 This holds true even where the initial attack may have been the result of provocation. ${ }^{57}$ Chasing or following the victim for some distance has sufficed to uphold a verdict of "deliberation." 58 The Missouri courts have routinely upheld findings of "deliberation" if the method of killing intrinsically requires more time to consummate, such as by poisoning, strangulation, suffocation, drowning or severe beating or stomping. ${ }^{59}$ The fact that a defendant could have halted an attack, yet persisted, has also been held to be evidence of "deliberation."60

Evidence of the defendant's conduct after an attack has been used to uphold the trier of fact's finding of "deliberation." Examples of this are the failure of the defendant to attempt to save the life of his wounded victim, ${ }^{61}$ or the hiding or disposal of the body of the victim. ${ }^{62}$ Even flight and disposing of the weapon has been deemed to be evidence

\footnotetext{
53 State v. Ervin, 979 S.W.2d 149, 159 (Mo. 1998); State v. Stacy, 913 S.W.2d 384, 386-87 (Mo.App. 1996).

$54 \quad$ State v. Davis, 653 S.W.2d 167, 172 (Mo.App. 1983).

55 State v. Mallett, 732 S.W.2d 527, 533 (Mo. 1987) (slipping out of handcuffs to attack police officers).

$56 \quad$ State v. Clark, 913 S.W.2d 399, 404 (Mo.App.1996) (three shots were fired); State v. Stacy, 913
} S.W.2d 384, 386 (Mo. App. 1996) (14 stab wounds); State v. Ervin, 979 S.W.2d at 159 (defendant bashed in the head of the victim several times and then threw him into a fire).

$57 \quad$ In State v. Santillan, 948 S.W.2d 574, 577 (Mo. 1997), the defendant twice shot the victim, who was dating his girlfriend. While such evidence was sufficient for a jury to find "deliberation" it was error not to give a second-degree murder instruction.

58 In State v. Hatfield, 465 S.W.2d 468 (Mo.1971), a conviction of first degree murder following a court trial was affirmed, where two men had a disagreement in a tavern and agreed to take their differences outside. As they were leaving one broke a beer bottle against the doorsill and pursued the other up the alley, inflicting fatal wounds with the broken bottle. Only seconds elapsed between the time the defendant armed himself and the infliction of the fatal wound, and the defendant was obviously in an agitated state.

$59 \quad$ State v. Parkus, 753 S.W.2d 881, 884-85 (Mo.1988) (choking); State v. Antwine, 743 S.W.2d 51, 72 (Mo. 1988) (stomping to death).

60 State v. Ervin, 979 S.W.2d at 159. In State v. Davis, 107 S.W.3d 410, 414-15 (Mo.App. 2003), the defendant stole a woman's car but her child was left attached to a seatbelt and dragging along the road as defendant made his get-away; defendant kept driving, though he was repeatedly told that the child was being dragged.

$61 \quad$ State v. Feltrop, 803 S.W.2d at 12.

62 Though such evidence can admittedly be consistent also with a cover-up or a second-degree murder: State v. Santillan, 948 S.W.2d at 576. 
of "deliberation." 63 Tying up the victim to prevent seeking aid is also evidence of "deliberation." 64

The lack of any meaningful distinction between "knowingly causing death" and "deliberation" has been challenged on due process grounds in the higher courts of the state, but to no avail. ${ }^{65}$ The result is that all intentional homicides based on feelings of revenge or carried out in connection with some other unlawful purpose, can be qualified as having been committed "with deliberation upon the matter." The jury may return a verdict of first-degree murder, thereby opening up the possibility of a death sentence, as long as there is insufficient evidence of "violent passion suddenly aroused by some provocation" 66 to justify a verdict of voluntary manslaughter. Thus, under Missouri law, prosecutors, judges and juries have virtually unlimited discretion to choose between first and second degree murder in all cases where an intent to kill is present.

In contrast to Missouri, several states that divide murder into degrees require a more precise distinction between the mental states required for non-capital second degree murder and a potentially capital finding of first degree murder. One of the leading states in this respect is California, which has interpreted its murder statute to require something more than mere pre-existing intent to kill to constitute "premeditation and deliberation." The seminal case involved a brutal killing of the 10 year-old daughter of defendant's girlfriend, committed when the defendant had been drinking, in which the defendant stabbed her 60 times. ${ }^{67}$ Missouri courts would have upheld a first degree "deliberate" murder conviction without problem in such a case. The California Supreme Court, on the other hand, held that the mere fact of the brutality of a killing and the infliction of multiple injuries would not itself be sufficient to prove "premeditation and deliberation." ${ }^{68}$ It noted that "the legislative classification of murder into two degrees would be meaningless if 'deliberation' and 'premeditation' were construed as requiring no more reflection than may be involved in the mere formation of a specific intent to

\footnotetext{
63 State v. Tisius, 92 S.W.3d at 764.

64 State v. Stacy, 913 S.W.2d 384, 386 (Mo. App. 1996).

65 State v. Rousan, 961 S.W.2d 831, 851-52 (Mo. 1998); State v. Middleton, 998 S.W.2d 520, 524 (Mo.1999); State v. Strong, 142 S.W.3d 702, 716 (Mo. 2004).

66 State v. Dickson, 691 S.W.2d 334, 339 (Mo. App. 1985); State v. Anderson, 384 S.W.2d 591, 608 (Mo. 1964).

$67 \quad$ People v. Anderson, 447 P.2d 942, 945 (Cal. 1968).

$68 \quad$ Id., at 947.
} 
kill. ${ }^{69}$ The California Supreme Court then listed three categories of evidence which could support a finding of first degree murder: (1) "planning activity -- facts regarding the defendant's behavior prior to the killing which might indicate a design to take life;" (2) facts about the defendant's prior relationship or behavior with the victim which might indicate a motive to kill; and (3) evidence regarding the nature or manner of the killing which indicate a deliberate intention to kill according to a preconceived design." ${ }^{70}$

The District of Columbia courts also require more than a mere intent to kill for a murder to rise to the first degree. The Court of Appeals has stated:

To speak of premeditation and deliberation which are instantaneous, or which take no appreciable time, is a contradiction in terms. It deprives the statutory requirement of all meaning and destroys the statutory distinction between first and second degree murder. At common law there were no degrees of murder. If the accused had no overwhelming provocation to kill, he was equally guilty whether he carried out his murderous intent at once or after mature reflection. Statutes like ours, which distinguish deliberate and premeditated murder from other murder, reflect a belief that one who meditates an intent to kill and then deliberately executes it is more dangerous, more culpable or less capable of reformation than one who kills on sudden impulse; or that the prospect of the death penalty is more likely to deter men from deliberate than from impulsive murder. The deliberate killer is guilty of first degree murder; the impulsive killer is not. $^{71}$

In accord with the California approach, the District of Columbia has held that even sordid, over-determined violent killings do not rise to murder of the first degree if they were committed "impulsively, in the heat of passion, or in an orgy of frenzied activity." 72

The California approach laid out in Anderson has also been adopted in Wyoming ${ }^{73}$ and West Virginia. ${ }^{74}$ The Arizona Supreme Court also recently cleared up the muddled difference between first and second degree murder by distancing itself from an interpretation of "premeditation" that allowed it to be found upon a mere pre-existing intent to kill and that did not require any actual proof of reflection. It held that "laws

\footnotetext{
$69 \quad$ Id., at 948.

Id. at 949 .

Bullock v. United States, 122 F.2d 213, 213-14 (D.C.App. 1941).

Hall v. United States, 454 A.2d 314, 317 (D.C.1982).

Neither the excessive brutality of a killing, nor the striking of repeated blows with a weapon are sufficient to establish premeditation. Bouwkamp v. State, 833 P.2d 486, 493-495 (Wyo. 1992).

74 State v. Guthrie, 461 S.E.2d 163, 180-81 (W.Va. 1995). The court held that the old "twinkling of an eye" instructions were "confusing, if not meaningless."
} 
must provide explicit standards for those charged with enforcing them and may not impermissibly delegate basic policy matters to policemen, judges, and juries for resolution on an ad hoc and subjective basis." ${ }^{75}$

In sum, if an intent to kill develops rashly as a result of motives that are insufficient to reduce a crime to voluntary manslaughter, Missouri calls such homicides "deliberate." Thus, numerous homicides that would be classified as non-capital second degree murder in California and other states are classified as first degree murder in Missouri, and are potentially death eligible.

\section{B. Statutory Aggravating Factors}

A defendant convicted of first-degree murder in Missouri is not eligible for capital punishment unless the prosecution proves one or more statutory aggravating factors beyond a reasonable doubt. ${ }^{76}$ The Missouri Penal Code lists seventeen statutory aggravating factors. This article uses the following abbreviations to refer to the seventeen statutory aggravators: prior record, ${ }^{77}$ multiple homicide, ${ }^{78}$ hazardous device, ${ }^{79}$ for money, ${ }^{80}$ public official, ${ }^{81}$ agent or employee, ${ }^{82}$ wantonly vile, ${ }^{83}$ peace officer, ${ }^{84}$

\footnotetext{
75 State v. Thompson, 65 P.3d 420, 424, 429 (Ariz. 2003).

$76 \quad$ V.A.M.S. $\S 565.030 .4$.
}

77 V.A.M.S. $§ 565.032 .2(1)$ ("The offense was committed by a person with a prior record of conviction for murder in the first degree, or the offense was committed by a person who has one or more serious assaultive criminal convictions.").

$78 \quad$ V.A.M.S. $§ 565.032 .2(2)$ ("The murder in the first degree was committed while the offender was engaged in the commission or attempted commission of another unlawful homicide.").

79 V.A.M.S. § 565.032.2(3) ("The offender by his act of murder in the first degree knowingly created a great risk of death to more than one person by means of a weapon or device which would normally be hazardous to the lives of more than one person.").

$80 \quad$ V.A.M.S. $§ 565.032 .2(4)$ ("The offender committed the offense of murder in the first degree for himself or another, for the purpose of receiving money or any other thing of monetary value from the victim of the murder or another.").

$81 \quad$ V.A.M.S. $§ 565.032 .2(5)$ ("The murder in the first degree was committed against a judicial officer, former judicial officer, prosecuting attorney or former prosecuting attorney, circuit attorney or former circuit attorney, assistant prosecuting attorney or former assistant prosecuting attorney, assistant circuit attorney or former assistant circuit attorney, peace officer or former peace officer, elected official or former elected official during or because of the exercise of his official duty.").

$82 \quad$ V.A.M.S. $§ 565.032 .2(6)$ ("The offender caused or directed another to commit murder in the first degree or committed murder in the first degree as an agent or employee of another person.").

${ }_{83}$ V.A.M.S. $\S 565.032 .2$ (7) ("The murder in the first degree was outrageously or wantonly vile, horrible or inhuman in that it involved torture, or depravity of mind.").

$84 \quad$ V.A.M.S. $§ 565.032 .2(8)$ ("The murder in the first degree was committed against any peace officer, or fireman while engaged in the performance of his official duty."). 
escaped custody, ${ }^{85}$ avoiding arrest, ${ }^{86}$ felony murder,${ }^{87}$ killing witness, ${ }^{88}$ corrections officer, ${ }^{89}$ hijacking, ${ }^{90}$ concealing drug crime, ${ }^{91}$ other drug crime, ${ }^{92}$ and gang activity. ${ }^{93}$

The number and breadth of statutory aggravators in Missouri tends to expand the class of death-eligible offenses, thereby broadening the scope of prosecutorial discretion. With seventeen statutory aggravating factors, Missouri ranks eighth among the 38 death penalty states in terms of the number of statutory aggravators. ${ }^{94}$ In general, states with a greater number of statutory aggravators give prosecutors more discretion to decide which cases should be charged as capital cases. The sheer number of aggravators is only part of the story, though, because states vary widely in the breadth of individual aggravators. It is not necessary for the purposes of this study to compare the breadth of statutory aggravators in different states. In Part V.B, infra, we provide a quantitative measurement of the breadth of statutory aggravators in Missouri.

\section{Voluntary Manslaughter}

$85 \quad$ V.A.M.S. $§ 565.032 .2(9)$ ("The murder in the first degree was committed by a person in, or who has escaped from, the lawful custody of a peace officer or place of lawful confinement.").

$86 \quad$ V.A.M.S. $§ 565.032 .2(10)$ ("The murder in the first degree was committed for the purpose of avoiding, interfering with, or preventing a lawful arrest or custody in a place of lawful confinement, of himself or another.").

$87 \quad$ V.A.M.S. $§ 565.032 .2(11)$ ("The murder in the first degree was committed while the defendant was engaged in the perpetration or was aiding or encouraging another person to perpetrate or attempt to perpetrate a felony of any degree of rape, sodomy, burglary, robbery, kidnapping, or any felony offense in chapter 195, RSMo.").

$88 \quad$ V.A.M.S. $§ 565.032 .2(12)$ ("The murdered individual was a witness or potential witness in any past or pending investigation or past or pending prosecution, and was killed as a result of his status as a witness or potential witness.").

$89 \quad$ V.A.M.S. $§ 565.032 .2(13)$ ("The murdered individual was an employee of an institution or facility of the department of corrections of this state or local correction agency and was killed in the course of performing his official duties, or the murdered individual was an inmate of such institution or facility.").

$90 \quad$ V.A.M.S. $§ 565.032 .2(14)$ ("The murdered individual was killed as a result of the hijacking of an airplane, train, ship, bus or other public conveyance.").

91 V.A.M.S. $§ 565.032 .2(15)$ ("The murder was committed for the purpose of concealing or attempting to conceal any felony offense defined in chapter 195, RSMo.").

$92 \quad$ V.A.M.S. $§ 565.032 .2(16)$ ("The murder was committed for the purpose of causing or attempting to cause a person to refrain from initiating or aiding in the prosecution of a felony offense defined in chapter 195, RSMo.").

93 V.A.M.S. $§ 565.032 .2(17)$ ("The murder was committed during the commission of a crime which is part of a pattern of criminal street gang activity as defined in section 578.421.").

94 The only jurisdictions with a larger number of aggravators are: California (28 aggravators), Cal. Penal Code ' 190.2(a); Delaware (22 aggravators), 11 Del.Code. ' 4209(e); Illinois (21 aggravators), 720 Ill. Cons. Stats. 5/9-1(b); Utah (19 aggravators), Utah Code Ann. 1953 ' 76-5-202 (1); Colorado (18 aggravators), Colo. Rev. Stats. Ann. ' 18-13-1201(5); Oregon (18 aggravators) Ore. Rev. Stats. ' $163.095(1-$ 2); and Pennsylvania (18 aggravators), 42 Pa.Cons. Stats. Ann. ' 9711(d). With 17 aggravators, Missouri is tied with Florida, West's Fla. Stats. Ann. ' 921.141(5), in eighth place among the 38 death penalty states. For the 42 federal offenses which may trigger the death penalty, see http://www.deathpenaltyinfo.org/article.php?scid=29\&did=192. 
In Missouri, the crime of voluntary manslaughter is defined as causing the death of another person under circumstances that would constitute murder, except that the death was caused "under the influence of sudden passion arising from adequate cause." 95 "Sudden passion" is defined as "passion directly caused by and arising out of provocation by the victim or another acting with the victim, which passion arises at the time of the offense and is not solely the result of former provocation." ${ }^{96}$ The offense must have been committed in sudden passion, and not after there has been time for the passion to cool. ${ }^{97}$

"Adequate cause" is "cause that would reasonably produce a degree of passion in a person of ordinary temperament sufficient to substantially impair an ordinary person's capacity for self-control." 98 To be "adequate," the provocation must be of a nature calculated to inflame the passions of the ordinary, reasonably temperate person. There must be a sudden, unexpected encounter or provocation tending to excite the passion beyond control. Passion may be rage, anger, ${ }^{99}$ or terror, but it must be so extreme that the action is being directed by passion, not reason. ${ }^{100}$ Words alone, no matter how opprobrious or insulting, are not sufficient to show adequate provocation. ${ }^{101}$

Over the past few decades, many states, influenced by the Model Penal Code, have broadened the category of homicides that qualify as voluntary manslaughter. ${ }^{102} \mathrm{In}$ Missouri, though, the traditional common law rules still apply. Consequently, some homicides that would be classified as voluntary manslaughter in states influenced by the

\footnotetext{
95 V.A.M.S. ' 565.023 ; State v. Redmond, 937 S.W.2d 205, 207 (Mo. 1996).

$96 \quad$ V.A.M.S.' $565.002(7)$.

97 State v. Fears, 803 S.W.2d 605, 609 (Mo. 1991). In states that follow the Model Penal Code, there is no "cooling time" restriction. Hence, even in cases where there has been a substantial lapse of time between the provocation and the killing, a defendant may still be eligible for a voluntary manslaughter instruction. See MPC ' 210.3(1)(b). See also Markus D. Dubber, Criminal Law: Model Penal Code 375-76 (2002); People v. Casassa, 404 N.E.2d 1310, 1314 (NY 1980).

$98 \quad$ V.A.M.S.' $565.002(1)$

$99 \quad$ State v. Blackman, 875 S.W.2d 122 (Mo.App.1994).

$100 \quad$ State v. Fears, 803 S.W.2d 605, 609 (Mo. 1991).

101 State v. Redmond, 937 S.W.2d at 208; State v. Starr, 38 Mo. 270, 277 (1866). Beginning with Maher v. People, 10 Mich. 212 (1862), some states began departing from the common law tenet that "mere words" could never amount to adequate provocation. See also Commonwealth v. Berry, 336 A.2d 262 (Pa. 1975); People v. Valentine, 169 P.2d 1, 1l-15 (Ca. 1946). Cf. WAYNe R. LaFAVE, Criminal LAW 708-09 (3d ed. 2000).

${ }_{102}$ Model Penal Code $\S 210.3(1)(b)$ classifies as manslaughter a "homicide which would otherwise be murder" when "committed under the influence of extreme mental or emotional disturbance for which there is reasonable explanation or excuse." At least 14 states have adopted this definition, which does not require provocation, may be triggered by "mere words" and is not necessarily invalidated by "cooling time." SANFord H. Kadish \& StePhen J. SChUlhofer, CRiminal LaW AND ITS Processes $418-19$ ( $7^{\text {th }}$ Ed. 2001).
} 
Model Penal Code are classified as murder in Missouri. Insofar as Missouri law narrows the class of defendants who are eligible to have their offense reduced from murder to voluntary manslaughter, the law expands the class of death-eligible defendants, thereby broadening the scope of prosecutorial discretion in choosing which cases merit capital punishment.

\section{Inadmissibility of Intoxication Evidence}

In Missouri, evidentiary rules related to intoxication also have the effect of broadening the class of death-eligible offenses. The majority of jurisdictions in the U.S. allow evidence of voluntary intoxication to negate the "premeditation and deliberation" required to constitute first-degree murder, and even the intent to kill necessary for a finding of murder in the second-degree. ${ }^{103}$ In contrast, Missouri law makes evidence of voluntary intoxication inadmissible in the jury's determination of the defendant's mental state. ${ }^{104}$ Although the U.S. Supreme Court has ruled that a similar Montana statute does not violate due process, ${ }^{105}$ the law does reduce the types of evidence a Missouri jury may consider in determining whether to find the defendant guilty of first-degree murder. Thus, homicides committed by intoxicated defendants, which might yield a verdict of second degree murder or voluntary manslaughter in other states, might well yield a conviction for first degree murder in Missouri, thereby making the crime potentially death eligible. ${ }^{106}$ Thus, the legislative decision to exclude evidence of voluntary intoxication effectively broadens the scope of prosecutorial discretion in choosing which crimes merit capital punishment.

\section{E. Proportionality Review}

For each death sentence that reaches the Missouri Supreme Court on direct review, the Court is required to determine whether "the sentence of death is excessive or

103 Roberts v. People, 19 Mich. 401 (1870); People v. Hood, 462 P.2d 370, 374 (Cal. 1969) Commonwealth v. Graves, 334 A.2d 661, 662-63 (Pa. 1975); Terry v. State, 465 N.E.2d 1085, 1087-88 (Ind. 1984); Cal. Penal Code ' 22 (1). See generally, LAFAVE, supra note _, at 412-16.

$104 \quad$ VAMS ' 562.076(3) provides: "Evidence that a person was in a voluntarily intoxicated or drugged condition may be admissible when otherwise relevant on issues of conduct but in no event shall it be admissible for the purpose of negating a mental state which is an element of the offense."

$105 \quad$ Montana v. Egelhoff, 518 U.S. 37, 56 (1996).

106 There are approximately ten other states that, like Missouri, preclude defendants from introducing evidence of voluntary intoxication. See SANFORd H. KAdish \& STEPHEN J. SChUlHOFER, CRiminal LAW AND ITS PROCESSES 870 (7th Ed. 2001). See LAFAVE, supra note , at 414 . 
disproportionate to the penalty imposed in similar cases, considering both the crime, the strength of the evidence and the defendant." 107 For the purpose of facilitating this review, the statute provides for an "assistant to the Supreme Court" who shall accumulate "the records of all cases in which the sentence of death or life imprisonment without probation or parole was imposed" and "provide the court with whatever extracted information the court desires with respect thereto," in order to assess proportionality. ${ }^{108}$

Missouri's proportionality statute mirrors that of the State of Georgia. ${ }^{109}$ In the wake of the Supreme Court's decision in Gregg v. Georgia, ${ }^{110}$ Missouri was one of twenty-six states that adopted a requirement of proportionality review modeled on the Georgia statute. ${ }^{111}$ After the U.S. Supreme Court decided that proportionality review was not required by the Eight Amendment, ${ }^{112}$ nine states repealed their proportionality review statutes, and several others abandoned the practice. ${ }^{113}$ At present, twenty of the 38 states that allow capital punishment maintain a statutory requirement for proportionality review. $^{114}$

In conducting proportionality review, the Missouri Supreme Court considers all cases in which a capital charge was submitted to the jury, but does not consider other

109 Under the Georgia scheme, the Supreme Court is required in every case to determine "[w]hether the sentence of death is excessive or disproportionate to the penalty imposed in similar cases, considering both the crime and the defendant." Ga.Code Ann. ' 17-10-35(c)(3) (1982). If the court affirms the death sentence, it is to include in its decision reference to similar cases that it has taken into consideration. ' 17-10-35(e). The court is required to maintain records of all capital felony cases in which the death penalty was imposed since 1970. ' 17-10-3.

$110 \quad 428$ U.S. 153 (1976).

111 Timothy V. Kaufman-Osborn, Capital Punishment, Proportionality Review, and Claims of Fairness (with Lessons from Washington State), 79 WASH. L. REV. 775, 790 (2004).

112 Pulley v. Harris, 465 U.S. 37, 50-51 (1984).

113 Kaufman-Osborn, supra note , at 791-96. For a list of the states that no longer conduct proportionality review, see State v. Bland, 958 S.W.2d 651, 663 (Tenn.1997).

$114 \quad$ Ala. Code '13A-5-53(b)(3) (1994); Del. Code Ann. tit. 11, '4209(g)(2)(a) (1995); Ga. Code Ann. '17-10-35(c)(3) (1997); Ky. Rev. Stat. Ann. '532.075(3)(c) (Michie 1999); La. Code Crim. Proc. Ann. art. 905.9.1(1)(c) (West 1997); Miss. Code Ann. '99-19-105(3)(c) (1999); Mo. Ann. Stat. '565.035.3(3) (West 1999); Mont. Code Ann. '46-18-310(1)(c) (1999); Neb. Rev. Stat. '29-2521.03 (1995); N.H. Rev. Stat. Ann. '630:5(XI)(c) (1996); N.J. Stat. Ann. '2C:11-3(e) (West 1995); N.M. Stat. Ann. '31-20A-4(C)(4) (Michie 2000); N.Y. Crim. Proc. Law '470.30(3)(b) (McKinney Supp. 2001); N.C. Gen. Stat. ' 15A-2000(d)(2) (1999); Ohio Rev. Code. Ann. '2929.05(A) (Anderson 1999); S.C. Code Ann. '16-3-25(c)(3) (Law. Co-op. 1985); S.D. Codified Laws ' 23A-27A-12(3) (Michie 1998); Tenn. Code Ann. 39-13-206(c)(1)(D) (1997); Va. Code Ann. '17.1-313(c)(2) (Michie 1999); and Wash. Rev. Code '10.95.130(2)(b) (1990).
} 
death-eligible cases. ${ }^{115}$ The issue for the Court is not whether the death sentence is appropriate for the particular individual, but whether any defendant in similar circumstances should be eligible for the death sentence. ${ }^{116}$ Only when the case, taken as a whole, is plainly lacking circumstances consistent with those in similar cases where a death penalty has been imposed will resentencing be ordered by the Supreme Court. ${ }^{117}$ If there are no prior similar cases on record, the Supreme Court will make an independent judgment as to whether the imposition of the death sentence is wanton or freakish under the facts of the case. ${ }^{118}$ Accomplices' plea agreements and convictions for crimes other than first degree murder are not considered in proportionality review of a death sentence. $^{119}$

In theory, the statutory requirement for proportionality review is designed to narrow the class of death-eligible offenses and narrow the scope of prosecutorial discretion. In practice, though, proportionality review does not actually have that effect because the Missouri Supreme Court's review is largely perfunctory. In fact, the Missouri Supreme Court has reversed only one death sentence as "disproportionate." 120 In a second case, the Court exercised its capital sentencing review authority to set aside a death sentence based on a combination of comparative weakness of evidence and favorable evidence of the defendant's background. ${ }^{121}$ Missouri's record of proportionality review is fairly typical. Of the state high court decisions in capital cases

115 State v. Lashley, 667 S.W.2d 712, 716 (Mo.1984); State v. Mercer, 618 S.W.2d 1, 10 B11 (year) (cited in Robert H. Dierker, 32 Mo. PraC., Missouri Criminal LaW $§ 57.10$ (2d ed. 2007) HTTP://WEB2.WESTLAW.COM/SEARCH/DEFAULT.WL?RS=WLW7.02\&FN= TOP\&SV=SPLIT\&DB=MOPRACCRIMLIT\&VR=2.0\&RP=\%2FSEARCH\%2FDEFAULT.WL\&MT=LAWSCHOOLPRACTITIONER. Missouri's approach to proportionality review is followed by seven other states, which also review cases that go to a penalty hearing along with those that result in a capital judgment. Eight states take the narrower approach and only consider death judgments. Finally, three states consider all death-eligible cases.

${ }_{116} \quad$ See State ex rel. Davis v. Shinn, 874 S.W.2d 403 (Mo.App.1994).

117 State v. Nunley, 923 S.W.2d 911 (Mo.1996).

118 State v. Ramsey, 864 S.W.2d 320 (Mo.1993).

119 State v. Edwards, 116 S.W.3d 511 (Mo.2003).

120 State v. McIlvoy, 629 S.W.2d 333 (Mo.1982). In that case, the Court appears to have been strongly influenced by the defendant's conduct in voluntarily surrendering to authorities. DIERKER, supra note _, '57.10.

121 - State v. Chaney, 967 S.W.2d 47 (Mo.1998). The Court concentrated for the first time on the "strength of the evidence" and went beyond its mere sufficiency. DIERKER, supra note 
rendered between 1975 and April 1996, only fifty-five death sentences were vacated on the ground of disproportionality, while 1376 death sentences were affirmed. ${ }^{122}$

\section{IV. Methodology and Research Design}

This study focuses on prosecutorial discretion in the implementation of capital punishment in Missouri. Specifically, the main objectives are: (a) to analyze correlations between prosecutorial discretion and disparate impacts on different racial and geographic groups within Missouri; and (b) to determine the extent to which statutory limitations constrain the exercise of prosecutorial discretion and promote consistent application of capital punishment across counties.

\section{A. Overview of Two Databases}

We began the study by creating a "large database" that includes substantially all of the intentional homicide cases prosecuted in Missouri over a five-year period. Specifically, the large database includes 1046 cases, all of which satisfy the following criteria: (1) the initial indictment or information is dated between Jan. 1, 1997 and Dec. 31, 2001; (2) the defendant was initially charged with either murder or voluntary manslaughter; ${ }^{123}$ and (3) the defendant was ultimately convicted of a homicide offense. For cases in the large database, we collected a very limited set of information that could be obtained from publicly available court documents. For the purposes of analysis, we divided the cases in the large database into two categories: "capital charges" and "noncapital cases." "Capital charges" are cases in which the prosecutor sought the death penalty at some point during the prosecution. For example, cases in which the prosecutor initially charged death, and then later accepted a plea bargain for a lesser sentence, count as capital charges for these purposes. All other cases in the large database are "noncapital cases."

122 Kaufman-Osborn, supra note _ at 792 (citing Donald H. Wallace \& Jonathan R. Sorenson, Comparative Proportionality Review: A Nationwide Examination of Reversed Death Sentences, 22 Am. J. Crim. Just. 13, 35 (1997).

123 Although cases charged as second-degree murder or voluntary manslaughter are not death-eligible under the statute, these cases are included because prosecutorial discretion affects the decision whether to charge a case as first-degree murder (M1), second-degree murder (M2), or voluntary manslaughter (VM). The analysis in Part V, infra, demonstrates that many of the cases charged as M2 or VM satisfy the statutory requirements for an M1 charge, and are death-eligible under the statute. 
After compiling the large database, we selected a "small sample" of cases to study in greater detail. The initial small sample included 129 capital charges, ${ }^{124}$ plus 130 noncapital cases that were selected at random from the large database, for a total initial sample size of 259 cases. Because the goal was to perform detailed analysis of cases in the small sample, we ultimately eliminated 18 defendants from the small sample about whom we were unable to obtain sufficient information, including 8 capital charges and 10 non-capital cases. We also added six more capital charges that we discovered after the initial creation of the small sample. Hence, the final small sample consists of 247 cases, including 127 capital charges and 120 non-capital cases.

\section{B. Creation of the Large Database}

Data in the large database is derived almost exclusively from records contained in county courthouses. There are 115 counties in Missouri, each with its own courthouse, its own records, and its own record-keeping system. Most of the collection of court documents for creation of the large database was completed in 2003. At that time, many county courthouses were not computerized and most of the counties that did maintain electronic records did not have an ability to search their databases electronically to identify all of the homicide cases in a given time period.

We relied primarily on a list provided by the Office of State Courts Administrator (OSCA) to identify cases for inclusion in the large database. ${ }^{125}$ In fall 2002, OSCA provided us a list of all the cases in Missouri with an initial charging date between Jan. 1, 1997 and Dec. 31, 2001 where the defendant was charged with either murder or voluntary manslaughter and the defendant was convicted of a homicide offense. OSCA refused to provide information about cases that were dismissed, or that resulted in non-guilty

124 The final large database includes 133 capital charges. However, data collection for the large database was incomplete at the time the small sample was created. At that time, we had identified only 129 cases as capital charges. All 129 cases that were identified as capital charges at that time were initially included in the small sample.

125 In 1994, the Missouri legislature appropriated funds to develop a statewide court automation system. See V.A.M.S. $\S 476.055$. Missouri Supreme Court Rules provide that the "office of state courts administrator will operate the court automation central computer sites." Rule 1.03. Supreme Court Rules also require all state courts to "report case information to the Office of State Courts Administrator." Rule 4.28. Thus, insofar as state courts comply with their reporting obligations, and insofar as OSCA manages the court automation system effectively, OSCA should have records of all the criminal cases prosecuted in Missouri since about the mid-1990s. 
verdicts, because that information is confidential. ${ }^{126}$ We verified and augmented the OSCA list by asking county clerks to double-check the information provided by OSCA. Most of the clerks said that they had no way of knowing whether the OSCA information was complete. A few clerks identified some cases that met our parameters that had been inadvertently omitted from the OSCA list. Thus, it is likely that the large database excludes a small number of intentional homicide cases within the time frame of this study that were inadvertently omitted from the OSCA list, and that county clerks were unable to identify. Even so, we are confident that the large database contains the vast majority of cases that satisfy our criteria for inclusion in the database. ${ }^{127}$

After obtaining the list of cases from OSCA, we sent law students to county courthouses to review courthouse records. The goal was to obtain a limited set of information about every case in the large database. ${ }^{128}$ To obtain the relevant information, we created a data collection form, a copy of which is reproduced in Annex A. We also

126 OSCA also refused to provide the names of defendants; all cases were identified only by case numbers. Every case that involved a change of venue was double-counted. If venue changed twice, the case was triple-counted. Thus, in the early stages, we devoted substantial effort to eliminating double and triple counting problems.

${ }_{127}$ There are several factors that support this conclusion. First, OSCA has a statutory mandate to collect information about all the criminal cases prosecuted in Missouri. See supra note _. County clerks report relevant information to OSCA on a regular basis. OSCA has established procedures for recording the information obtained from county clerks in its database. Undoubtedly, there are data entry and other errors that affect the accuracy of OSCA's data. However, OSCA's procedures provide safeguards to minimize such errors.

One county that has an exceptionally good computerized case management system is Pulaski County. In the early phases of data collection, we were able to check the accuracy and completeness of the OSCA data for Pulaski County by comparing the OSCA data to Pulaski's own data. (The clerk in Pulaski County had records of about 25 cases, most of which were transferred to Pulaski on change of venue motions. The cases that originated in other counties do not count as "Pulaski cases" in our final tabulation.) This process revealed that cases charged as "capital murder," rather than "first-degree murder," were inadvertently omitted from the data initially provided by OSCA. OSCA then corrected that omission by providing an additional list of cases charged as "capital murder." In the end, we identified only ten cases that were omitted from the final OSCA list, suggesting that the list was substantially complete.

128 For every case in the large database, we collected copies of the following documents: a docket sheet (if available); the initial indictment or information; any amended indictment or information; the sentence and judgment form; the plea agreement (if the case resulted in a guilty plea); the verdict form (if the case went to trial); and the notice of aggravating circumstances (for cases where the prosecutor sought death). For cases initially charged as M2 or VM, students merely reviewed enough of the file to confirm that there was no M1 charge, collect the relevant documents, and complete the data collection form. For cases initially charged as M1, students reviewed the entire file to determine whether there was any evidence that the prosecutor sought the death penalty at any time during the process. In addition to the documents noted above, they collected additional documentation that provided evidence that the prosecutor did, or did not, seek the death penalty (e.g., pre-trial motions opposing capital punishment, jury instructions, etc.) The information recorded on the data collection forms was entered into an electronic database; that is the large database. 
prepared detailed instructions for students about how to complete the data collection form. Ultimately, students visited 83 of the 115 county courthouses in Missouri. There were nine counties that did not have any murder or voluntary manslaughter cases in the time frame under study. There were also 23 counties that had one or two M2 or VM cases, but no M1 cases. County clerks sent us documentation for the cases from those counties, but students did not visit the courthouses to review records. ${ }^{129}$

Problems of Inclusion and Exclusion: We included cases on the basis of initial charging date (rather than, for example, disposition dates or crime dates). Specifically, we included cases where the first indictment or information was filed between January 1, 1997 and December 31, 2001. ${ }^{130}$ Cases charged before Dec. 31, 2001 are included even if there was no final disposition until several years later. ${ }^{131}$ Cases initially charged as murder or voluntary manslaughter are included, even if the defendant was ultimately convicted of a lesser offense, such as involuntary manslaughter. Cases in which charges were dismissed, and those that resulted in not guilty verdicts, are excluded from the database, both because the individuals were not demonstrably guilty, and because the records are not publicly available. ${ }^{132}$

Counting Issues: For the purpose of counting cases, the unit of analysis is a "defendant-crime," except as provided below. Because we focus on the initial charging decisions of prosecutors, a single initial charging decision by a specific prosecutor against a single defendant for a specific crime generally counts as one case. Consistent

129

The primary reason for sending students to visit county courthouses was so that students could review the entire file for every case initially charged as M1 to obtain documentation necessary to determine whether a case should be classified as a "capital charge." For cases initially charged as M2 or VM, there was no need to review the entire file because those cases are all "non-capital cases." Therefore, if a county did not report any M1 cases, there was no need for students to visit the courthouse.

130 There are 15 cases included in the large database where the initial indictment or information was filed before January 1, 1997, the defendant's conviction was reversed on appeal, and prosecutors filed a writ of habeas corpus ad prosequendum to initiate a new prosecution between January 1, 1997 and December 31, 2001. The rationale for including these cases is that we are studying prosecutorial charging decisions in a given time frame. Because the decision to file a writ of habeas corpus ad prosequendum is essentially a new charging decision, we count the filing of such a writ as the initiation of a new case if it is filed within our time frame.

131 In September 2006, we deleted four cases from the large database that had still not reached a final disposition. In one such case, the attorneys were still debating whether the defendant was competent to stand trial. In another case, the defendant absconded and was never found. At the same time, we also deleted two cases where the clerk was never able to locate the file.

132 Because we are investigating the charging decisions of prosecutors, excluding the subset of defendants who are found not guilty could potentially introduce some bias in our estimates. Having been found not guilty suggests that the prosecutor's charging decision was more aggressive in these cases. 
with this counting rubric, if a prosecution was initiated in County $\mathrm{X}$ and there was a change of venue to County Y, we count that as one case (one initial charge), not two cases. ${ }^{133}$ If two or more co-defendants were charged with the same crime, we count the case against each co-defendant as a separate case. If one defendant committed a series of homicides in separate incidents, each incident is counted separately. If one defendant was charged with multiple homicides in a single incident, we count that as one case. There are a few cases in which the defendant was charged with murder in an indictment filed after Jan. 1, 1997, the defendant's conviction was reversed on appeal, and the prosecutor filed a writ of habeas corpus ad prosequendum before Dec. 31, 2001. These cases are counted as two cases because they involve two independent charging decisions by a prosecutor. ${ }^{134}$

Division into Capital Charges and Non-capital Cases: In general, when a prosecutor in Missouri decides to seek the death penalty, he or she files a "notice of aggravating circumstances." For our purposes, every case in which the prosecutor filed a notice of aggravating circumstances counts as a capital charge, even if the prosecutor later agreed to a plea bargain that provided for a lesser sentence. Moreover, a case counts as a capital charge if the defendant pled guilty to first-degree murder and accepted a sentence of life without parole, even if there was no notice of aggravating circumstances in the file. ${ }^{135}$ Additionally, there are a few cases in the database for which there was no notice of aggravating circumstances in the file, but there was other documentation indicating that the prosecutor sought the death penalty. Examples of such other documentation include entries on docket sheets, jury instructions, and defense motions to

133 Under Missouri law, in every criminal case triable by a jury, the defendant is entitled to an automatic change of venue if the initial charges are filed in a county with a population less than 75,000 . Mo. Sup. Ct. Rules of Crim. Proc., Rule 32.03(a). Thus, most of the cases initiated in small counties were transferred to other counties before trial. Overall 161 out of 1046 cases in the large database changed venue at least once.

134 The large database includes 8 cases that are "double-counted" in this way. There is no optimal way to deal with these cases. They are not two truly independent cases. However, if these cases were treated as one case, it would present a problem whether to count the initial decision or a subsequent decision. For example, if the death penalty was originally sought, but not sought in the second trial, did the defendant face a death trial? Our decision to treat the cases as two separate cases is also consistent with our treatment of other cases involving separate trials outside our time period.

135 We assume that a defendant would not plead guilty to first-degree murder and accept a sentence of life without parole unless the prosecution had at least threatened to seek the death penalty. However, in three cases where defendant pled guilty to first-degree murder and accepted a sentence of life without parole, there is affirmative evidence that the prosecution did not seek the death penalty. Those cases are not counted as capital charges. 
preclude the application of capital punishment. A case counts as a capital charge if such other documentation shows clearly that the prosecutor sought capital punishment at some time during the process. ${ }^{136}$

\section{Creation of the Small Sample}

As noted above, the final small sample includes 247 cases. We sought information about these cases from six different sources: 1) the court records that had been collected for creation of the large database; 2) a web-based database called "Case.net", which provides access to the Missouri State Courts Automated Case Management System; ${ }^{137}$ 3) published appellate opinions; 4) newspaper articles; 5) criminal history record information (CHRI) obtained from the FBI; and 6) police reports obtained from the state and local law enforcement agencies that investigated the homicides.

For the vast majority of cases in the small sample, the police reports provide the most detailed factual information about the case. There were two reasons why we decided to rely primarily on police reports, rather than trial transcripts, to obtain detailed factual information about the cases. First, and most importantly, relying solely on those cases that went to trial would introduce significant bias in the sample, since fewer than half of the cases in the small sample actually went to trial. ${ }^{138}$ Second, we were operating on a limited budget, and it was less expensive to collect police reports for all the small sample cases than it would have been to obtain trial transcripts for the sub-set of cases that went to trial.

Collection of police reports was generally a two-step process. First, we contacted county prosecutors to find out which law enforcement agency maintained the investigative file for each case. (Some files are held by county sheriffs, some by city police departments, and some by the Missouri State Highway Patrol.) Second, we contacted the law enforcement agencies directly to obtain copies of the investigative

\footnotetext{
136 The final small sample includes 127 capital charges. Our files contain a notice of aggravating circumstances for 108 of those cases.

137 Case.net data is available at http://www.courts.mo.gov/casenet/base/welcome.do. Case.net does not provide information about the underlying facts of homicide cases, but it does provide basic information about the judicial process, such as charging and sentencing information. To access information on Case.net, one must have a case number or the defendant's name (or both).

${ }_{138}$ The final small sample of 247 cases includes 137 cases resolved by guilty pleas, 17 cases decided by bench trials, and 93 cases decided by jury trials.
} 
reports. ${ }^{139}$ Cooperation from prosecutors and law enforcement officials was uneven. Some were eager to provide the requested information. Others were reluctant to do so, despite the fact that police investigative reports are classified as public records under the Missouri Sunshine Act after a case becomes "inactive." 140

We were unable to collect police reports for some cases that remained "active" as of fall 2006, when we halted data collection efforts. We were also unable to collect police reports for some inactive cases because the relevant public officials refused to provide the requested information. ${ }^{141}$ Ultimately, we eliminated 17 cases from the small sample due to inadequate information, resulting in a final sample of 247 cases. $^{142} \mathrm{We}$ successfully obtained police reports for most of those 247 cases. The final small sample includes 48 defendants for whom we never obtained police reports; we retained those cases because we were able to obtain sufficient information from appellate opinions and other sources to merit inclusion in the small sample.

We created two different data entry forms for the small sample cases. The main data entry form is a 13-page form. We provided a detailed set of written instructions to assist students in completing the form. For each case in the small sample, a law student reviewed the police reports, court documents and appellate opinions, and completed the data entry form on that basis. If the review of those documents left key questions unanswered, students used Case.net to provide supplemental information about the judicial process, and newspaper articles to provide supplemental information about the underlying facts. After students completed the data entry forms, a law professor

139 The level of detail contained in police investigative reports varies widely. Some reports consist of hundreds of pages of documentation. Others include only about a dozen pages. There is no standard format for these reports and there do not appear to be any guidelines specifying the type of information to be included.

140 The Sunshine Act distinguishes among "arrest reports," "incident reports," and "investigative reports." V.A.M.S. § 610.100.1. All incident reports and arrest reports are public records. V.A.M.S. § 610.100.2. However, to obtain detailed factual information about a case, it is necessary to procure the investigative report. Investigative reports are initially closed; they become open records once an investigation is no longer active. Guyer v. City of Kirkwood, 38 S.W.3d 412 (MO banc, 2001). An investigation is active until "the convictions of all persons convicted on the basis of the information contained in the investigative report" are final, either "by exhaustion of or expiration of all rights of appeal of such persons." V.A.M.S. § 610.100.1(3)(c).

141 In other states, where researchers have been given a legislative mandate to conduct similar studies, it appears that public officials have been very forthcoming in providing researchers all available data. Obviously, the refusal of some Missouri officials to provide requested information affects the reliability of conclusions that can be drawn on the basis of the data collected.

$142 \quad$ See supra note _ and accompanying text. 
reviewed the forms and raised questions about issues that were unclear. Students modified the forms on that basis. Then, after the revisions were complete, other research assistants entered the data from those forms into an electronic database. This data was linked with the criminal history records of defendants, provided by the FBI.

We created a separate data entry form for the small sample cases to provide specific information about aggravating circumstances. The Missouri death penalty statute has seventeen aggravating circumstances. ${ }^{143}$ The "aggravator form" lists the seventeen statutory aggravators. Law students reviewed the case files and completed one aggravator form for each case in the small sample. For every case, students provided one of three possible answers for each aggravator: 1) the prosecutor actually charged this aggravator; 2) the prosecutor could have charged this aggravator, but did not; or 3) there is insufficient evidence to support this aggravator. ${ }^{144}$ Before students completed any of the aggravator forms, one student reviewed Missouri Supreme Court decisions interpreting the aggravating factors and provided a summary of relevant case law that served as guidance for the students who completed the aggravator forms. Students completed aggravator forms for the capital charges before they completed forms for the non-capital cases. Once they completed review of the capital charges, we used that information to summarize the actual charging practices of prosecutors in cases where prosecutors charged aggravators. The summary of charging practices provided additional guidance to students in evaluating which aggravators prosecutors "could have charged" in the non-capital cases.

Students provided a narrative summary of each case at the end of the aggravator form. A law professor reviewed every aggravator form for completeness and accuracy by comparing the entries for individual aggravators to the summary at the end of the form. For two of the seventeen statutory aggravators, the process involved one additional step. The "prior record" aggravator relates to the defendant's prior criminal record. A law professor modified the student responses for that aggravator based upon a review of the criminal history record information (CHRI) that we obtained from the FBI. The "wantonly vile" aggravator is the broadest and vaguest statutory aggravating factor; it

$143 \quad$ V.A.M.S. $\S 565.032$.

144 A prosecutor "could have charged" an aggravator if he or she could make a good faith, reasonable argument in support of a decision to charge that aggravator in a particular case. 
applies to any murder that "was outrageously or wantonly vile, horrible or inhuman in that it involved torture, or depravity of mind." 145 For every case in which prosecutors did not charge that aggravator, a law professor reviewed the narrative summary and made an independent determination as to whether the prosecutor could have charged the "wantonly vile" aggravator in that case. Once this analysis was completed, all of the data from the aggravator forms was electronically recorded.

\section{Analytical Methodology}

The analysis in the remainder of this paper is divided into three parts. Part V measures the extent to which statutory constraints limit the exercise of prosecutorial discretion in charging decisions. Part VI provides unadjusted measures of geographic and racial disparities in the decision-making process that determines which defendants are convicted of first-degree murder, and which defendants are convicted of lesser included offenses. (The term "unadjusted measures" means that these measures do not control for the culpability of individual defendants.) Part VII provides unadjusted measures of geographic and racial disparities in the decision-making process that determines which defendants are sentenced to death.

We define the term "M1-eligible" to mean that a reasonably aggressive prosecutor could make a good faith, reasonable argument that the statutory requirements for an M1 charge are satisfied. We define the term "death-eligible" to mean that a reasonably aggressive prosecutor could make a good faith, reasonable argument that the statutory requirements for a capital charge are satisfied. In Part V, we analyze cases that were initially charged as M2 or VM to derive an estimate of the percentage of cases in the large database that are M1-eligible. Similarly, we analyze cases that were not charged as capital cases to derive an estimate of the percentage of cases in the large database that are death-eligible. The estimates of the percentage of cases that are M-1 eligible and deatheligible provide a rough quantitative measure of the extent to which statutory constraints limit the exercise of prosecutorial discretion.

The analysis in Part VI examines racial, geographic, and socioeconomic disparities at different points in the decision tree depicted below. Figure 4.1 provides a

145 V.A.M.S. $\S 565.032 .2(7)$. The Missouri Supreme Court has adopted an expansive interpretation of this aggravator, making it potentially applicable to almost every murder. See infra notes __ and accompanying text. 
simplified schematic of the process for deciding which defendants who commit intentional homicide should be convicted of first-degree murder. There are

FIGURE 4.1

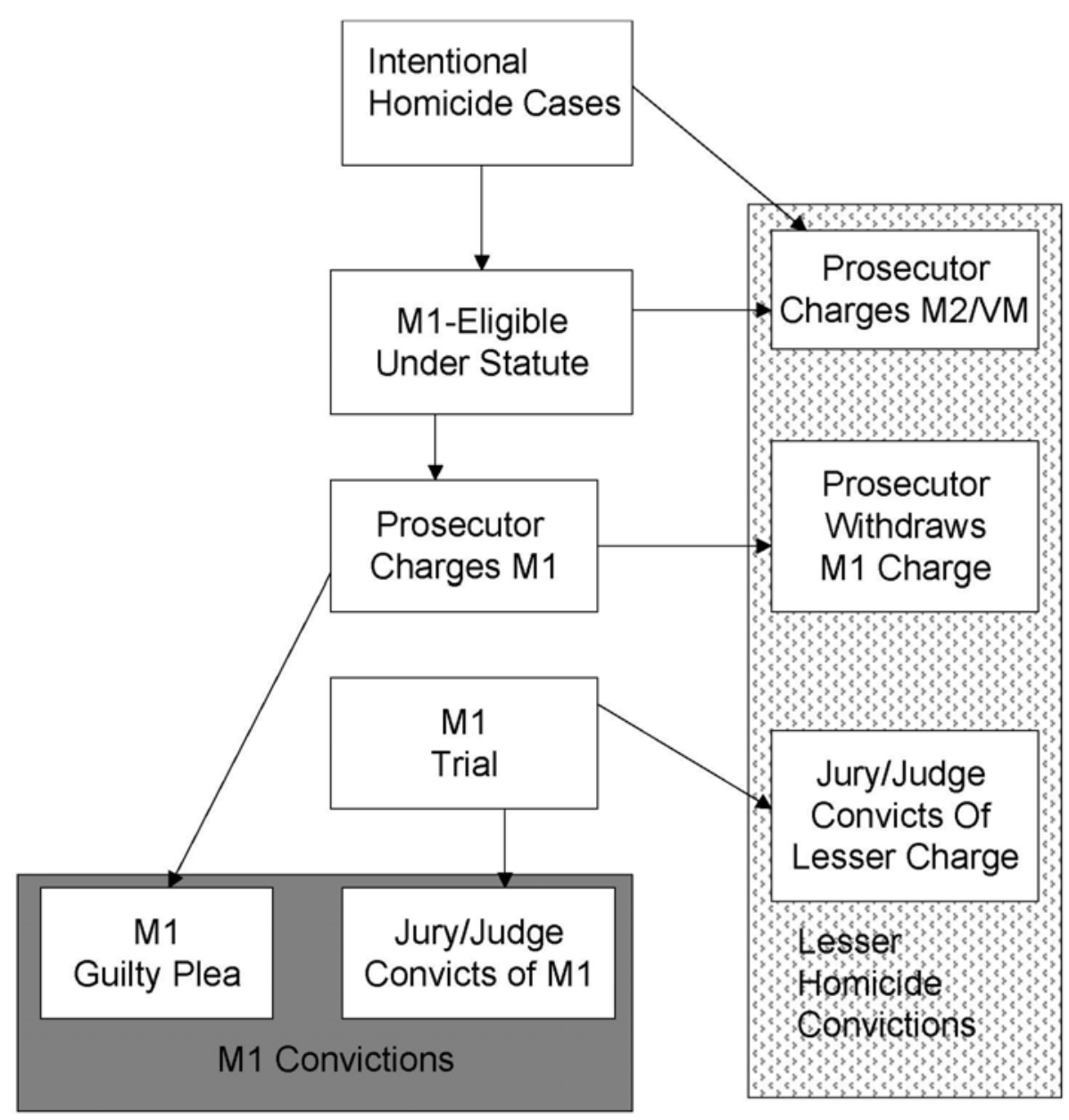

basically four steps in that process. First, the legislature eliminates some cases by deciding that they are not M1-eligible under the statute. Second, the prosecutor eliminates other cases by deciding not to file M1 charges. Third, the prosecutor eliminates more cases by withdrawing the M1 charge in cases initially charged as M1. Fourth, the jury (or judge in a bench trial) further narrows the field by convicting the defendant of a lesser included offense in a case tried as a first-degree murder case. The cases remaining after these four distinct narrowing functions have been performed are the M1 convictions. Part V focuses on the first step in the process: it measures the 
percentage of intentional homicide cases that the statute eliminates from the class of M1eligible offenses. Part VI examines geographic and racial disparities in the implementation of the next three steps: prosecutorial charging decisions, plea bargaining decisions, and trial decisions by the factfinders.

Part VII examines geographic and racial disparities at different points in the decision tree depicted below. Figure 4.2 provides a simplified schematic of the process for deciding which defendants who commit intentional homicide should be sentenced to death. First, the legislature eliminates some cases by deciding that they are not deatheligible under the statute. Second, the prosecutor eliminates other cases by deciding not to file capital charges. Third, the prosecutor eliminates more cases by accepting plea agreements for non-death sentences in cases initially charged as capital cases. Fourth, the jury (or judge in a bench trial) further narrows the field by convicting the defendant of M2 or VM, or by voting for life without parole instead of the death penalty. The cases remaining after these four distinct narrowing functions have been performed are the death sentences. Part V focuses on the first step in the process: it measures the percentage of intentional homicide cases that the statute eliminates from the class of death-eligible offenses. Part VII examines geographic and racial disparities in the implementation of the next three steps: prosecutorial charging decisions, plea bargaining decisions, and decisions at trial by the factfinders. 


\section{FIGURE 4.2}

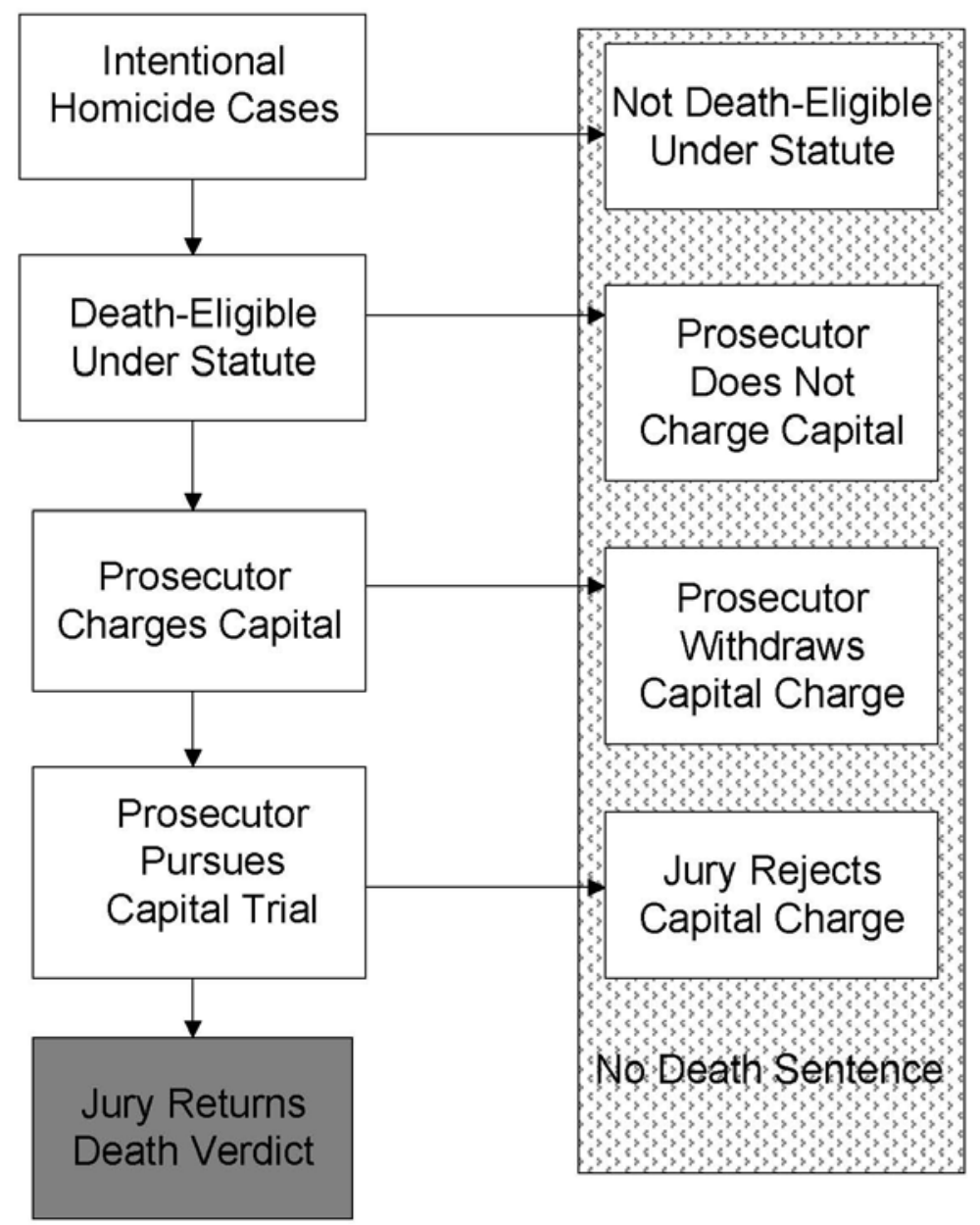

To provide measures of geographic disparities, we analyze the complete universe of cases in the large database because, for every case in the large database, the database contains information about the county of origin and the decisions made in each stage of the decision process depicted above. To provide measures of racial disparities, we derive estimates from the small sample because information about race of victims and race of defendants is available only for cases in the small sample. Those estimates are based on a weighted average that accounts for the sampling method we employed. The small sample includes all capital charges (probability of inclusion $=100 \%$ ) and 130 randomly 
selected non-capital cases (14.2\% of 915 cases). ${ }^{146}$ We weight by the inverse of the probability of inclusion in the small sample (so called "probability weights"), where cases are weighted to represent the equivalent number of cases in the universe of cases. Thus, capital charges are weighted one (each capital charge in the small sample represents one capital charge in the universe of cases) and non-capital cases are weighted 7.09 (each non-capital case in the small sample represents about 7.09 non-capital cases in the universe of cases). We also control for the finite size of the universe of cases in determining standard errors and test statistics. We use the same weighted averaging method in Parts VI and VII.

\section{Statutory Constraints on Prosecutorial Discretion}

This Part measures the extent to which statutory constraints limit the exercise of prosecutorial discretion in charging decisions. Part Five is divided into three sections. The first section analyzes statutory constraints on prosecutorial discretion to charge a crime as M1 versus M2. The second section analyzes constraints on prosecutorial discretion to file capital charges. The third section evaluates the narrowing effects of statutory aggravating factors.

\section{A. First Degree versus Second Degree Murder}

We define the term "M1-eligible" to mean that a reasonably aggressive prosecutor could make a good faith, reasonable argument that the statutory requirements for an M1 charge are satisfied. Using conservative assumptions, we estimate that 62.3 percent of the cases in the large database that were initially charged as M2 or VM satisfy the statutory requirements for an M1 charge. Overall, we estimate that 84.5 percent of the cases in the large database are M1-eligible under the statute. These estimates are derived as follows.

There are 1046 cases in the large database, including 617 cases initially charged as M1, and 429 cases initially charged as M2 or VM. We want to know how many of the 429 cases charged as M2 or VM are M1-eligible. To answer this question, it is necessary

146 As noted above, the final small sample includes only 120 non-capital cases because we eliminated several cases due to inadequate information. See supra notes _ and accompanying text. However, at the time we initially selected the small sample, we randomly selected 130 non-capital cases from a universe of 915 non-capital cases. We used those figures to determine the proper weighting for a weighted average. 
to extrapolate from the cases in the small sample because we do not have sufficient information about all the cases in the large database to answer this question for every case in the large database. There are 247 cases in the small sample, including 61 cases that were initially charged as either M2 or VM. Law students reviewed the files for all 247 cases and prepared a narrative summary for each case. ${ }^{147}$ Once the summaries were finalized, two law professors independently reviewed the summaries for all 61 cases that were initially charged as either M2 or VM to determine which cases were M1-eligible. For each case, each professor answered either "yes" or "no" to the question whether the case was M1-eligible. There were 38 cases that both professors agreed are M-1 eligible, and 53 cases that at least one professor thought was M1-eligible. Conservatively, using only the 38 cases for which both professors agreed, ${ }^{148}$ we estimate that $62.3 \%$ of the small sample cases initially charged as M2 or VM are M1-eligible under the statute. ${ }^{149}$ Assuming that $100 \%$ of the cases in the large database that were initially charged as M1 are M1-eligible under the statute, and assuming that $62.3 \%$ of the cases that were initially charged as M2 or VM are M1-eligible under the statute, we estimate that $84.5 \%$ of the intentional homicide cases prosecuted in Missouri are M1-eligible under the statute. ${ }^{150}$

Figure 5.1 compares the influence of the statute to the influence of prosecutorial discretion in determining which cases yield M1 convictions. Given that $84.5 \%$ of the intentional homicide cases prosecuted in Missouri are M1-eligible under the statute, it follows that the statute eliminates only about $15.5 \%$ of the cases from the class of M1eligible offenses. Prosecutors filed M1 charges in only $69.8 \%$ of the M1-eligible cases.

\footnotetext{
$147 \quad$ See supra Part IV.C.

If one uses the higher figure of 53 cases that at least one professor thought were M1-eligible, this would suggest that $86.9 \%$ of the cases initially charged as M2 or VM are M1-eligible.

149 Because we are extrapolating from a sub-sample of data, there is additional error in this estimate. To be precise, the conservative estimate is that $62 \% \pm 12 \%$ are M1-eligible.

$150 \quad(1.00 \times 617)+(.623 \times 429)=.845 \times 1046$. Incorporating the error in the original $62.3 \%$ estimate, our conservative estimate is that $84.5 \% \pm 5.8 \%$ of the cases in the large database are M1-eligible. If one used the more liberal estimate that 53 out of $61 \mathrm{M} 2 / \mathrm{VM}$ cases in the small sample are M1-eligible, a similar calculation yields the estimate that about 94.6 percent of the cases in the large database are M1-eligible.
} 


\section{FIGURE 5.1}

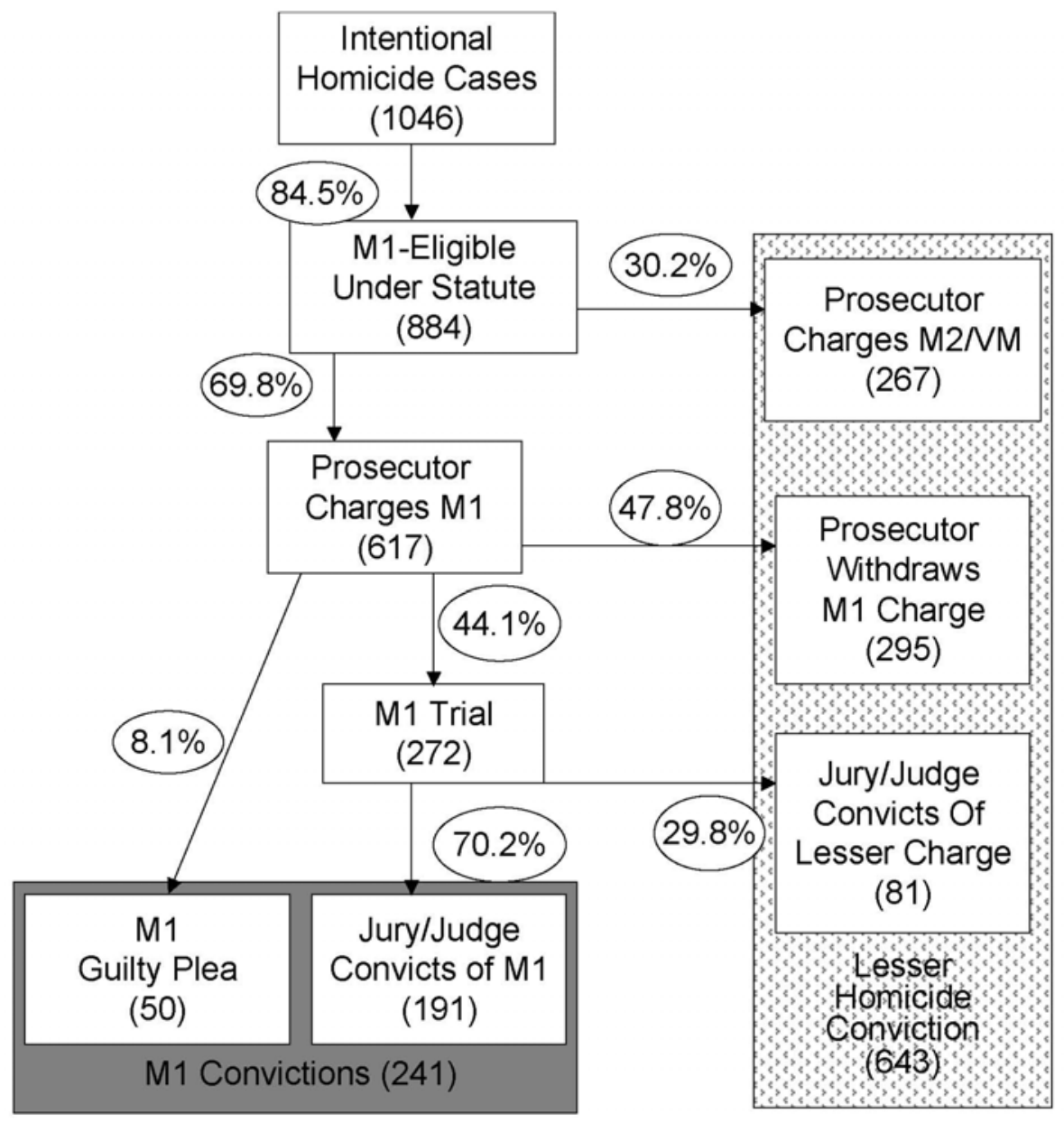

In effect, this means that prosecutors eliminated $30.2 \%$ of the M1-eligible cases by choosing not to file an M1 charge. Moreover, prosecutors eliminated $47.8 \%$ of the cases initially charged as M1 by voluntarily reducing the M1 charge. ${ }^{151}$ Overall, discretionary choices by prosecutors eliminated about $53.7 \%$ of the intentional homicide cases from the M1 category, ${ }^{152}$ whereas the statute eliminated only about $15.5 \%$ of the cases from the M1 category. Thus, prosecutors do about 3.5 times more "work" than the statute in narrowing the class of intentional homicide cases to yield M1 convictions.

151 The vast majority of cases in which prosecutors withdrew M1 charges were resolved by guilty pleas. Indeed, 284 out of 295 cases in this group were resolved by guilty pleas. The other 11 cases in this category are cases where the prosecutor filed an amended information before trial to reduce the charge from M1 to M2.

$152 \quad(267+295) / 1046=.537$ 
It bears emphasis that the minimum penalty for an M1 conviction is harsher than the maximum penalty for an M2 conviction. The statute provides only two possible sentences for a defendant convicted of M1: death, or life without parole (LWOP). ${ }^{153}$ In contrast, the maximum penalty for a defendant convicted of M2 is life with parole, and the minimum penalty is ten years imprisonment. ${ }^{154}$ Of the 1046 cases in the large database, 241 defendants were convicted of M1 and 805 defendants were convicted of lesser included offenses. ${ }^{155}$ The $241 \mathrm{M} 1$ convictions yielded 26 death sentences and 215 LWOP sentences. In contrast, the 805 cases where defendants were convicted of lesser included offenses yielded 151 life sentences and 651 fixed term sentences. ${ }^{156}$ The average sentence for defendants sentenced to a term of years was 15.79 years.

In sum, there is a huge difference in sentencing outcomes between defendants convicted of M1 and defendants convicted of lesser included offenses. But despite that difference, the statute gives prosecutors extremely broad discretion to choose which defendants should be convicted of M1, and which defendants should be convicted of lesser offenses. Thus, the Missouri statute effectively delegates to prosecutors the legislative task of determining which types of homicides merit harsher punishment.

The Missouri legislature could amend the statutory definition of "deliberation" to require evidence of advance planning or a preconceived design; this is the approach adopted by California, Arizona, West Virginia and other states. ${ }^{157}$ We estimate that only $15 \%$ of the cases initially charged as M2 or VM would be M1-eligible under the revised statute (compared to at least $62.3 \%$ under the existing statute), and about $60 \%$ of the cases initially charged as M1 would remain M1 eligible. Overall, we estimate that only $36 \%$ of the cases in the large database, would be M1-eligible under the revised statute (compared to at least $84.5 \%$ under the current statute). ${ }^{158}$ Hence, this type of statutory

\footnotetext{
$153 \quad$ V.A.M.S. $\S 565.020(2)$.

$154 \quad$ See V.A.M.S. $\S \S 565.021(2), 558.011(1)(1)$.

155 This figure includes $542 \mathrm{M} 2$ convictions, 138 voluntary manslaughter convictions, and 125 convictions for other offenses, most of which were involuntary manslaughter.

156 The large database includes three cases where defendants were convicted of M2, but we lack information about sentencing outcomes.

$157 \quad$ See supra notes _ and accompanying text.

158 These estimates are derived as follows. A law professor reviewed the narrative summaries for every case in the small sample. For each case, he answered "yes" or "no" to the question whether a reasonably aggressive prosecutor could make a good faith charge of M1 under a California-type statute. We divided the results into three categories: cases charged as M1 capital charges, cases charged as M1 non-
} 
amendment would significantly constrain prosecutorial discretion in choosing which cases to charge as M1 and which cases to charge as M2.

\section{B. Prosecutorial Discretion and the Choice Between Life and Death}

The small sample contains a total of 247 cases; under the most liberal assumptions, the small sample includes 239 cases that are M1-eligible. ${ }^{159}$ Those 239 cases include 127 capital charges and 112 non-capital cases. Our analysis of aggravating factors shows that one or more statutory aggravating factors are present in 99 of the 112 M1-eligible cases that were not charged as capital cases. (An aggravator is present in a case if the prosecutor actually charged that aggravator, or if the prosecutor could make a good-faith, reasonable decision to charge that aggravator.) Thus, $88.4 \%$ of the M1eligible, non-capital cases in the small sample are death-eligible under the statute. This represents a conservative estimate of the percentage of M1-eligible cases that are deatheligible under the statute.

In Table 5.1, we use this 88.4 percent figure to derive two different estimates of the percentage of death-eligible cases in the large database. In Part V.A above, we provided a conservative estimate that $84.5 \%$ of the cases in the large database are M1eligible. ${ }^{160}$ We also noted the more liberal estimate that as many as $94.6 \%$ of the cases may be M1-eligible. ${ }^{161}$ Using the conservative figure, we estimate that approximately 76.2 percent of the intentional homicide cases prosecuted in Missouri are death-eligible under the statute. If one uses the more liberal figure, this yields an estimate that about 85.2 percent of the intentional homicide cases are death-eligible. ${ }^{162}$

capital cases, and cases charged as M2 or VM. We assumed that, for each of these three categories, the percentage of cases that would be M1-eligible under the revised statute is the same for the large database as it is for the small sample. Based on that assumption, we estimated the number of large database cases in each category that would be M1-eligible under the revised statute, and derived an estimate for the large database as a whole on that basis.

${ }_{159}$ As discussed above, two law professors independently analyzed the 61 small sample cases that were initially charged as M2 or VM to ascertain which ones were not M1-eligible. See supra notes _ and accompanying text. There were only eight cases that both professors agreed were not M1-eligible. For present purposes, we assume that those eight cases are not M1-eligible, and all the others are M1-eligible. Subtracting those eight cases from the total of 247 small sample cases, we assume that the small sample contains 239 M1-eligible cases.

160 See supra notes __ and accompanying text.

161 See supra note

162 These estimates assume that $100 \%$ of the capital charges in the large database are death-eligible under the statute, and $88.4 \%$ of the M1-eligible non-capital cases are death-eligible. 
TABLE 5.1

\begin{tabular}{|l|c|c|}
\hline & Conservative Estimate & Liberal Estimate \\
\hline M1-Eligible Under Statute & $84.5 \%$ & $94.6 \%$ \\
\hline Death Eligible Under Statute & $76.2 \%$ & $85.2 \%$ \\
\hline
\end{tabular}

Figure 5.2 illustrates the process by means of which defendants sentenced to death are selected from the class of death-eligible defendants. Here, we use the conservative estimate that $76.2 \%$ of the intentional homicide cases prosecuted in Missouri are death-eligible under the statute. Figure 5.2 shows that prosecutors filed capital charges in only $16.7 \%$ of the death-eligible cases. Moreover, prosecutors withdrew the capital charge in more than $60 \%$ of the cases that were initially charged as capital cases. ${ }^{163}$ Overall, only 53 cases resulted in capital trials, ${ }^{164}$ and juries returned death verdicts in 26 cases. In sum, in the process of generating 26 death verdicts out of 1046 cases, the statute eliminated about $24 \%$ of the cases from the class of death-eligible offenses, prosecutors eliminated about $71 \%$ of the cases from the pool, ${ }^{165}$ and juries weeded out only $2.6 \%$ of the cases. ${ }^{166}$ Thus, discretionary choice by individual prosecutors is the dominant factor shaping decisions about who will live and who will die. $^{167}$

163 Prosecutors withdrew capital charges in 80 of the 133 cases that were initially charged as capital cases. Those 80 cases include 64 cases resolved by guilty pleas, 11 cases that were tried before a judge (after the capital charge was withdrawn), and 5 cases that were tried before a jury (after the capital charge was withdrawn).

164 The 53 capital trials include 4 bench trials and 49 jury trials. The 49 jury trials include 4 cases where a prosecutor charged death and presented an M1 charge to a jury, but the jury returned a verdict of M2 or VM. Those cases are counted as "capital trials" even though the cases never reached a penalty phase. Similarly, the 4 bench trials include 3 cases where a prosecutor charged death and presented an M1 charge to a judge in a bench trial, but the judge returned a verdict of M2. Those cases are also counted as capital trials even though the cases never reached a penalty phase. Finally, the "capital trial" category includes one case from Jackson County where the parties agreed to conduct penalty phase proceedings before a judge, instead of a jury.

$165 \quad(664+80) / 1046=.711$

$166 \quad 27 / 1046=.258$

167 Of course, prosecutors make decisions partly based upon their understanding of how a jury would react. This fact does not negate the significant amount of discretionary power that prosecutors hold. 


\section{FIGURE 5.2}

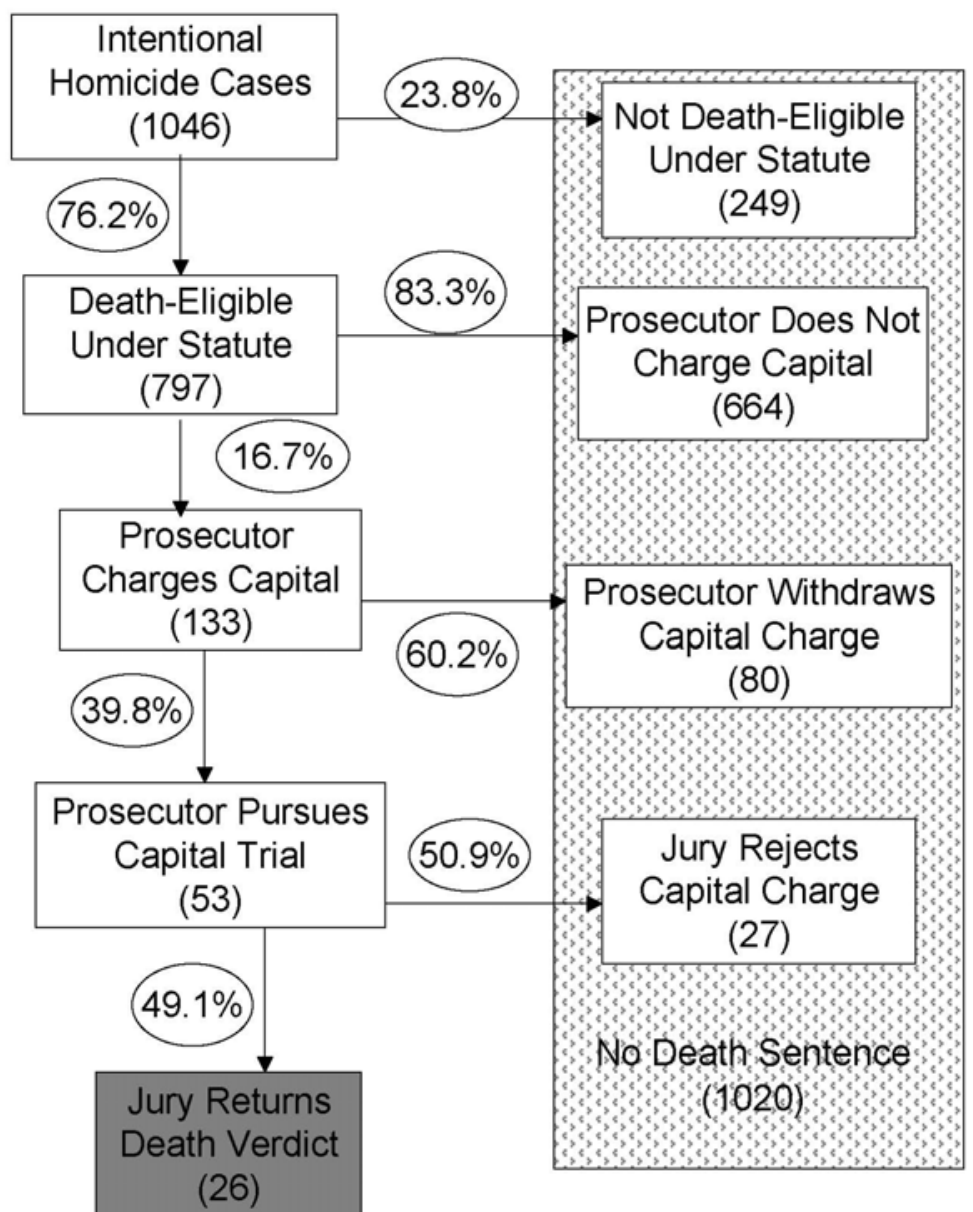




\section{The Narrowing Effects of Statutory Aggravating Factors}

Table 5.2 estimates the percentage of cases in the large database that are M-1 eligible, but not death-eligible. This figure measures the extent to which the statutory aggravators narrow the class of death-eligible offenses. Using the conservative estimate that $84.5 \%$ of intentional homicide cases are M1-eligible under the statute, we estimate that the requirement to prove one or more statutory aggravators eliminates only 8.3 percent of the total cases from the class of death-eligible offenses. If we use the more liberal estimate that $94.6 \%$ of intentional homicide cases are M1-eligible under the statute, it follows that the requirement to prove a statutory aggravator eliminates about 9.5 percent of the total cases from the class of death-eligible offenses. ${ }^{168}$ In light of these figures, it is doubtful whether the Missouri statute satisfies the constitutional requirement, articulated in Zant v. Stephens, that aggravating circumstances "must genuinely narrow the class of persons eligible for the death penalty." 169

TABLE 5.2

\begin{tabular}{|l|c|c|}
\hline & Conservative Estimate & Liberal Estimate \\
\hline M1-Eligible Under Statute & $84.5 \%$ & $94.6 \%$ \\
\hline $\begin{array}{l}\text { M1-Eligible, but Not } \\
\text { Death Eligible }\end{array}$ & $8.3 \%$ & $9.5 \%$ \\
\hline
\end{tabular}

The failure of Missouri's statutory aggravators to narrow the class of deatheligible offenses is primarily attributable to two factors. First, seventeen statutory aggravating factors is a large number of aggravators. The sheer number of statutory aggravators tends to broaden the class of death-eligible offenses. Second, there are six aggravating factors, in particular, that exacerbate this broadening effect: wantonly vile, felony murder, killing witness, avoiding arrest, for money, and agent/employee. ${ }^{170}$ Table 5.3 summarizes the application of Missouri's statutory aggravating factors.

\footnotetext{
168 The derivation of the percentages in the first row of Table 5.2 is explained in Part V.A above. See supra notes and accompanying text. In Part V.B, we estimated that $88.4 \%$ of the M1-eligible cases are death eligible. See supra notes _ and accompanying text. The percentages in the bottom row of Table 5.2 are derived by using the percentages in the top row to estimate the number of M1-eligible cases, and then using the $88.4 \%$ figure to estimate the number of death-eligible cases.

169462 U.S. 862, 877 (1983).

170 See supra Part III.B for statutory definitions of these aggravators.
} 
The left-hand column lists the seventeen aggravating factors, ranking them in terms of the number of cases in which a particular aggravator is present. The next column shows the number of cases in which prosecutors actually charged a particular aggravator. Although there are 127 capital charges in the small sample, there are only 108 cases for which we obtained information about the actual charging of aggravators. The figures in the PAC column reflect the actual usage of aggravators in those 108 cases. In contrast, the two right-hand columns are based upon our analysis of all 239 M1eligible cases in the small sample. The column labeled "could have charged" indicates the number of cases in which the prosecutor could make a good faith, reasonable argument in support of a decision to charge that aggravator, but did not; it therefore does not include the cases in which the prosecutor actually charged that aggravator. The righthand column shows the percentage of M1-eligible cases in which particular aggravating factors are present.

TABLE 5.3

APPLICATION OF STATUTORY AGGRAVATING FACTORS

\begin{tabular}{|l|c|c|c|}
\hline Aggravator & $\begin{array}{c}\text { Prosecutor } \\
\text { Actually Charged } \\
\text { (PAC) }(\mathrm{n}=108)\end{array}$ & $\begin{array}{c}\text { Prosecutor Could } \\
\text { Have, But Did Not } \\
\text { Charge (CHC) } \\
(\mathrm{n}=239)\end{array}$ & $\begin{array}{c}\text { Aggravator Present } \\
\text { (PAC + CHC) } \\
(\mathrm{n}=239)\end{array}$ \\
\hline Wantonly Vile & 94 & 125 & $219(91.6 \%)$ \\
\hline Felony Murder & 67 & 58 & $125(52.3 \%)$ \\
\hline Killing Witness & 33 & 86 & $119(49.8 \%)$ \\
\hline Avoiding Arrest & 28 & 88 & $116(48.5 \%)$ \\
\hline For Money & 51 & 56 & $107(44.8 \%)$ \\
\hline Agent/Employee & 22 & 76 & $98(41.0 \%)$ \\
\hline Multiple Homicide & 34 & 21 & $55(23.0 \%)$ \\
\hline Prior Record & 30 & 22 & $52(21.8 \%)$ \\
\hline Hazardous Device & 12 & 21 & $33(13.8 \%)$ \\
\hline Conceal Drug Crime & 3 & 5 & $8(3.3 \%)$ \\
\hline Escape Custody & 5 & 2 & $7(2.9 \%)$ \\
\hline Gang Activity & 1 & 5 & $6(2.5 \%)$ \\
\hline Peace Officer & 6 & 0 & $6(2.5 \%)$ \\
\hline Public Official & 3 & 3 & $6(2.5 \%)$ \\
\hline Other Drug Crime & 1 & 4 & $5(2.1 \%)$ \\
\hline Corrections Officer & 1 & 4 & $5(2.1 \%)$ \\
\hline Hijacking & 0 & 0 & 0 \\
\hline
\end{tabular}


The single broadest aggravating factor is the "wantonly vile" aggravator. The Missouri Supreme Court has construed this factor very broadly. The court has approved the application of this aggravator in cases involving: multiple injuries to the victim; ${ }^{171} \mathrm{a}$ series of attacks directed at the victim; ${ }^{172}$ a period of time in which the victim is aware of his/her impending death; ${ }^{173}$ and where a victim was bound prior to the killing. ${ }^{174}$ The court has also approved the application of this aggravator in cases where: the defendant was motivated by pecuniary gain; ${ }^{175}$ the defendant manifested a lack of remorse; ${ }^{176}$ the victim was chosen at random; ${ }^{177}$ and the murder was one of a series of murders. ${ }^{178}$ Given the broad range of circumstances in which the Missouri Supreme Court has approved the application of this aggravator, there are very few M1-eligible murders that do not satisfy the "wantonly vile" aggravator.

Apart from the "wantonly vile" aggravator, the two most frequently charged aggravators are the "felony murder" and "for money" aggravators, charged in 67 and 51 cases, respectively. Prosecutors often charge both aggravators in cases where the defendant commits robbery and/or burglary in conjunction with the murder. ${ }^{179}$ The felony murder aggravator also applies to cases involving rape, sodomy, kidnapping and certain drug crimes. ${ }^{180}$ The "for money" aggravator also applies in murder-for-hire cases, and in cases where the defendant kills the victim to obtain an inheritance. ${ }^{181}$ These two aggravators tend to broaden the class of death-eligible offenses, not because the

\footnotetext{
171 See, e.g., State v. Strong, 142 S.W.3d 702 (Mo. 2004).

172 See, e.g., State v. Mercer, 618 S.W.2d 1 (Mo. 1981).

173 See, e.g., State v. Tisius, 92 S.W.3d 751 (Mo. 2002); State v. Brown, 902 S.W.2d. 278 (Mo. 1995); State v. McMillin, 783 S.W.2d 82 (Mo. 1990).

174 See, e.g., State v. Brown, 902 S.W.2d. 278 (Mo. 1995); State v. McMillin, 783 S.W.2d 82 (Mo. 1990).

175 See, e.g., State v. Gill, 167 S.W.3d 184 (Mo. 2005).

176 See, e.g., State v. Griffin, 756 S.W.2d 475, 490 (Mo. 1988); State v. Preston, 673 S.W.2d 1, 11 (Mo. 1984).

177 See, e.g., State v. Clayton, 995 S.W.2d 468 (Mo. 1999); State v. Leisure, 749 S.W.2d 366 (Mo. 1988).

178 See, e.g., State v. Anderson, 79 S.W.3d 420 (Mo. 2002).

179 Prosecutors charged the "felony murder" aggravator in 40 out of 51 cases where they charged the "for money" aggravator.

180 V.A.M.S. § 565.032.2(11) ("The murder in the first degree was committed while the defendant was engaged in the perpetration or was aiding or encouraging another person to perpetrate or attempt to perpetrate a felony of any degree of rape, sodomy, burglary, robbery, kidnapping, or any felony offense in chapter 195, RSMo.").

181 See, e.g., State v. Bannister, 680 S.W.2d 141 (Mo. 1984) (murder for hire); State v. Davis, 814 S.W.2d 593 (Mo. 1991) (inheritance).
} 
Supreme Court has construed them broadly, but because the statutory provisions, on their face, apply to most of the M1-eligible homicides committed in Missouri. In fact, at least one of the two factors is present in about 60 percent of the M1-eligible cases. ${ }^{182}$

Two other statutory aggravating factors - the "killing witness" and "avoiding arrest" aggravators - are both present in almost fifty percent of the M1-eligible cases. ${ }^{183}$ If one examines the statutory language for these two aggravators, it appears that they address two different types of situations. The "killing witness" aggravator applies to any case where "the murdered individual was a witness or potential witness in any past or pending investigation . . .."184 The "avoiding arrest" aggravator applies where the murder "was committed for the purpose of avoiding, interfering with, or preventing a lawful arrest." 185 In practice, though, both aggravators apply in virtually the same set of cases. ${ }^{186}$ This is because the Missouri Supreme Court has construed both aggravators to apply in any case where a defendant kills a victim after the victim has seen the defendant commit some other crime. Thus, for example, if a defendant robs a victim, and then kills the victim one minute later, the court says that both aggravators are present because the victim was a witness to his own robbery, and the defendant killed the victim to avoid arrest for the robbery. ${ }^{187}$

Rounding out the list of the six broadest aggravators, the "agent or employee" aggravator is present in about $41 \%$ of the M1-eligible cases. The Missouri Supreme Court has upheld the application of this aggravator in murder-for-hire situations, ${ }^{188}$ and in

182 The "felony murder" aggravator is present in $52.3 \%$ of the cases. The "for money" aggravator is present in $44.8 \%$ of the cases. See Table 5.3. However, there is not a perfect overlap between the two aggravators. There are a total of 89 cases in which both factors are present. Additionally, there are 54 other cases in which one of the two factors is present. Thus, at least one of the two factors is present in $143 / 239$ cases, or about $59.8 \%$ of the M1-eligible cases.

183 The "killing witness" aggravator is present in $49.8 \%$ of the cases. The avoiding arrest aggravator is present in $48.5 \%$ of the cases. See Table 5.3 .

$184 \quad$ V.A.M.S. $§ 565.032 .2(12)$.

$185 \quad$ V.A.M.S. $\$ 565.032 .2(10)$.

186 The "avoiding arrest" aggravator is present in 115 out of 119 cases where the "killing witness" aggravator is present. Similarly, the "killing witness" aggravator is present in 115 out of 116 cases where the "avoiding arrest" aggravator is present.

187 See e.g., State v. Simmons, 955 S.W.2d 752 (Mo. 1997) (upholding application of "killing witness" aggravator in a robbery/murder case); State v. Brown, 902 S.W.2d 278 (Mo. 1995) (upholding application of both "killing witness" and "avoiding arrest" aggravators in kidnapping/murder case); State v. Kilgore, 771 S.W.2d 57 (Mo. 1989) (upholding application of "avoiding arrest" aggravator in a robbery/murder case).

$188 \quad$ See, e.g., State v. Basile, 942 S.W.2d 342 (Mo. 1997). 
cases where the defendant killed the victim in response to the verbal encouragement of a co-defendant. ${ }^{189}$ Prosecutors have charged this aggravator in cases where there is a conspiracy to commit murder, including cases that do not involve a typical agency or employment relationship between co-defendants. ${ }^{190}$ Prosecutors also charged this aggravator in a case where two co-defendants jointly committed a non-homicide offense, and one of the co-defendants subsequently killed the victim, contrary to the express wishes of the other co-defendant. ${ }^{191}$ Thus, in practice, this aggravator applies to any case where two co-defendants jointly commit a crime that results in death, even if they did not conspire to commit murder.

Under the current statute, $100 \%$ of the capital charges in the large database are death-eligible. In Part V.B above, we estimated that $88.4 \%$ of the M1-eligible, noncapital cases are death-eligible under the current statute. Overall, about $76.2 \%$ of intentional homicides are death eligible. If the legislature amended the statute by eliminating the six broadest statutory aggravating factors, the percentage of death-eligible cases would decline dramatically. Under the revised statute, we estimate that only $58 \%$ of the capital charges in the large database would be death-eligible, and only $37 \%$ of the M1-eligible, non-capital cases would be death-eligible. ${ }^{192}$ Overall, we estimate that only $40 \%$ of the M1-eligible cases in the large database would be death-eligible under the revised statute.

189 See, e.g., State v. Ringo, 30 S.W.3d 811 (Mo. 2000) (after two co-defendants robbed a restaurant and forced victim to hand over money from a safe, one co-defendant shot victim in response to verbal encouragement from the other co-defendant).

$190 \quad$ For example, in small sample case numbers 5002 and 5003 the two co-defendants conspired to kill and rob the victim. They lured the victim to defendant's place and beat the victim to death with a bat. The prosecutor sought death and charged the "agent/employee" aggravator against both defendants.

191 In small sample case numbers 1702 and 1705, two co-defendants conspired to assault a victim. After beating the victim until he was probably unconscious, defendant 1702 set the victim's house on fire, contrary to the express wishes of defendant 1705. The victim was alive when the fire started but died from carbon monoxide poisoning caused by the fire. The prosecutor brought capital charges and charged the "agent/employee" aggravator against both defendants.

192 These figures are derived from aggravator data coded into our small sample. See supra notes and accompanying text (explaining the aggravator form). For each case in the small sample, the file records one of three possible entries for each of the seventeen statutory aggravators: the prosecutor actually charged that aggravator (PAC), the prosecutor could have charged that aggravator, but did not (CHC), or there is no evidence to support that aggravator (NE). We determine whether a case is death-eligible under this alternative scenario by deleting the six aggravators and then determining whether a prosecutor did or could have charged at least one of the remaining aggravators. 
In sum, under the current statute, statutory aggravating factors eliminate only about 8-10 percent of the cases from the class of death-eligible offenses. ${ }^{193}$ Consequently, approximately $88.4 \%$ percent of the M1-eligible, non-capital cases are death-eligible under the statute, and about 76.2 percent of the total cases are deatheligible under the statute. ${ }^{194}$ Under this statutory scheme, the Missouri legislature has arguably abdicated its responsibility to "make the law" governing capital punishment and delegated that responsibility to individual prosecutors. A revised statute, with a smaller number of narrowly drawn aggravating factors, would shift the locus of decision-making from prosecutors to legislators and would help satisfy the constitutional requirement that aggravating circumstances "must genuinely narrow the class of persons eligible for the death penalty." 195

\section{VI}

\section{Disparate Impact in Homicide Cases}

As noted above, the Missouri homicide statute gives prosecutors extremely broad discretion to choose which defendants should be convicted of M1, and which defendants should be convicted of lesser included offenses. At the same time, there are substantial differences in sentencing outcomes between defendants convicted of M1 and defendants

convicted of lesser included offenses. ${ }^{196}$ This combination of factors - broad discretion and substantial differences in sentencing outcomes - raises questions about whether the exercise of discretion by different prosecutors affects different groups of people in significantly different ways.

\footnotetext{
$193 \quad$ See supra Table 5.2.

194 See supra Part V.B.

$195 \quad$ Zant v. Stephens, 462 U.S. 862, 877 (1983).

196 See supra notes _ and accompanying text.
} 


\section{FIGURE 6.1}

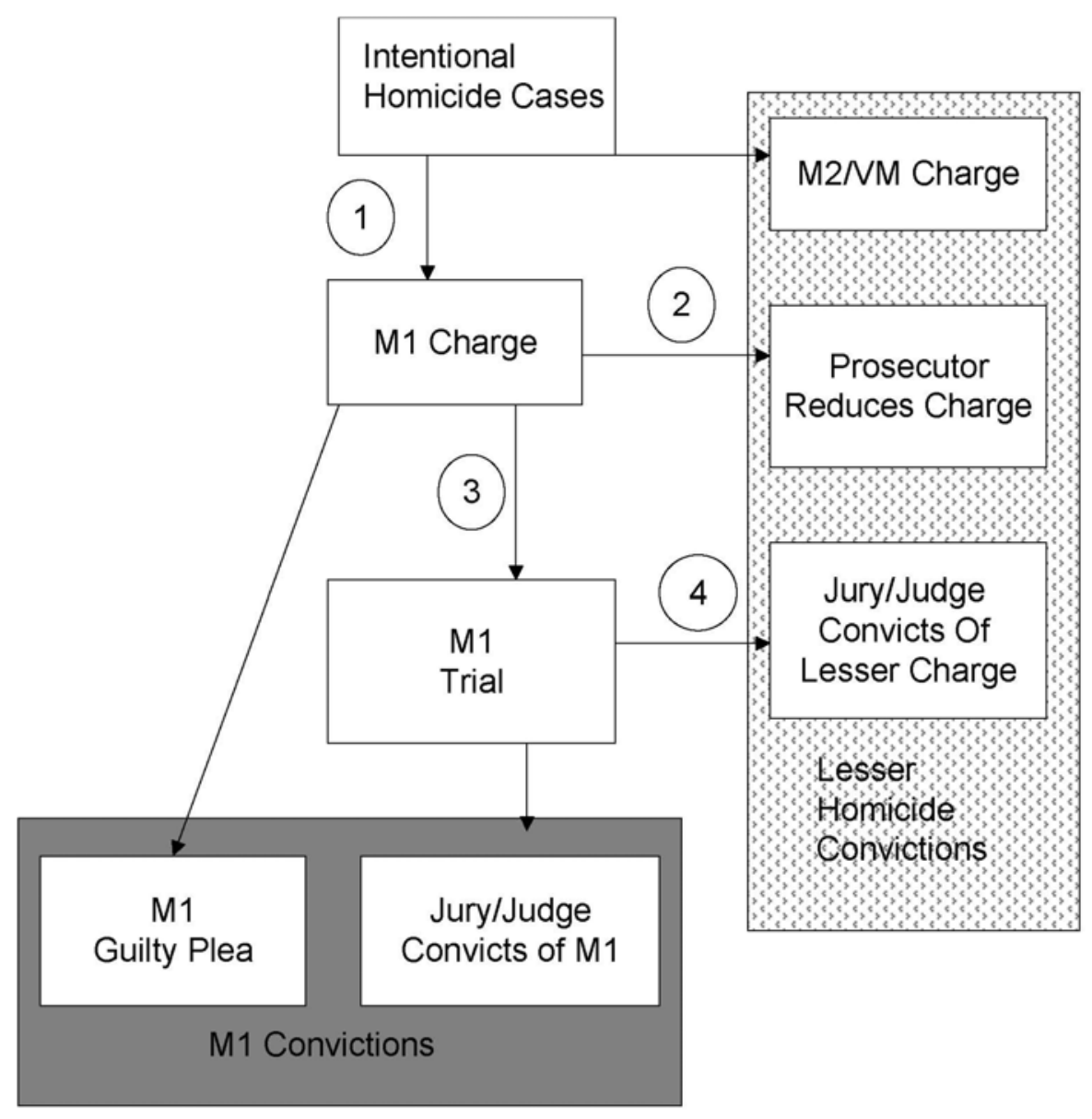

Figure 6.1 depicts the process that produces decisions about which defendants are convicted of M1 and which defendants are convicted of lesser included offenses. Part VI examines racial and geographic disparities at different points in that decision-making process, focusing on the four decision points identified in Figure 6.1, as well as the M1 outcomes at the bottom of the picture. The first section examines geographic disparities and the second section analyzes racial disparities. The final section presents the results of a regression analysis that examines the interactions among these two sets of variables.

Throughout Part VI, the data tables have column headings identical to the headings in Table 6.1 below. The headings of columns 1-4 correspond to the points labeled 1, 2, 3, and 4 in Figure 6.1. The percentages in the top row are unweighted. The percentages in the bottom row are based on weighted averages, as explained in Part IV.D 
above. The number in parentheses in each cell is the number of cases upon which the percentage in that cell is based.

The percentages in columns 1-4 are calculated on the basis of the previous node in the decision tree. Thus, the percentage in the top row of column 1 means that prosecutors filed an M1 charge in 59 percent of all intentional homicide cases. The percentage in the top row of column 2 means that prosecutors withdrew the M1 charge in 47.8 percent of the cases that were charged as M1. Because column 3 corresponds to the number 3 in Figure 6.1, the denominator of the fraction in column 3 is the number of cases charged as M1. Similarly, the denominator of the fraction in column 4 is the number of cases in which prosecutors pursued an M1 charge at trial.

\section{TABLE 6.1}

\begin{tabular}{|c|c|c|c|c|c|c|}
\hline & $\begin{array}{c}\text { Prosecutor } \\
\text { Charged } \\
\text { M1 } \\
\text { (1) }\end{array}$ & $\begin{array}{c}\text { Prosecutor } \\
\text { Withdrew } \\
\text { M1 Charge } \\
\text { (2) }\end{array}$ & $\begin{array}{c}\text { Pros. Took } \\
\text { M1 Charge } \\
\text { to Trial } \\
\text { (3) }\end{array}$ & $\begin{array}{c}\text { Jury/Judge } \\
\text { Convicted of } \\
\text { Lesser } \\
\text { Charge } \\
(4) \\
\end{array}$ & $\begin{array}{c}\text { M1 } \\
\text { Convictions } \\
\text { after M1 } \\
\text { Charge } \\
(5) \\
\end{array}$ & $\begin{array}{c}\text { Total M1 } \\
\text { Convictions } \\
\\
(6) \\
\end{array}$ \\
\hline $\begin{array}{l}\text { Large D- } \\
\text { base } \\
(1046 \\
\text { Cases) }\end{array}$ & $\begin{array}{l}59.0 \% \\
(1046)\end{array}$ & $\begin{array}{c}47.8 \% \\
(617)\end{array}$ & $\begin{array}{c}44.1 \% \\
(617)\end{array}$ & $\begin{array}{c}29.8 \% \\
(272)\end{array}$ & $\begin{array}{l}39.1 \% \\
(617)\end{array}$ & $\begin{array}{l}23.0 \% \\
(1046)\end{array}$ \\
\hline $\begin{array}{l}\text { Small } \\
\text { Sample } \\
(247 \\
\text { Cases) }\end{array}$ & $\begin{array}{c}55.8 \% \\
(247)\end{array}$ & $\begin{array}{c}43.6 \% \\
(186)\end{array}$ & $\begin{array}{c}46.8 \% \\
(186)\end{array}$ & $\begin{array}{c}33.3 \% \\
(91)\end{array}$ & $\begin{array}{l}40.8 \% \\
(186)\end{array}$ & $\begin{array}{c}22.8 \% \\
(247)\end{array}$ \\
\hline
\end{tabular}

Columns 5 and 6 display two different percentages. For both percentages, the numerator is the sum of all M1 convictions, including M1 guilty pleas and M1 jury verdicts, which is the shaded area in Figure 6.1. The denominator for the percentage in column 5 is the number of cases in which the prosecutor filed an M1 charge. The denominator for the percentage in column 6 is the universe of all intentional homicide cases. We utilize the same format for all the remaining tables in Part VI to analyze geographic, racial and socioeconomic disparities. Table 6.1 also demonstrates that our small sample reasonably represents the large sample, as one would expect from our sampling methodology. 


\section{A. Geographic Disparity}

Tables 6.2(A) to 6.2(C) present data on geographic disparity in the process for deciding which defendants are convicted of first-degree murder. In all three tables, St. Louis City and Jackson County (Kansas City) ${ }^{197}$ are treated as separate geographic units. Table 6.2(A) divides the other Missouri counties into two groups: MSA and rural. ${ }^{198}$ Table 6.2(B) divides the other Missouri counties into three groups according to the percentage of the non-white people included in the jury pool. ${ }^{199}$ Table 6.2(C) combines these measures by dividing the other Missouri counties in both ways: rural vs. MSA and high vs. low percentage of non-whites in the jury pool, thus presenting the results from the interaction of jury pool demographics and rural vs. MSA. In each column, we also note the statistical significance of the pattern of percentages across that column. ${ }^{200}$

Several features of the data presented in Table 6.2 are noteworthy. First, prosecutors in Jackson County charged M1 at a much lower rate than prosecutors in the rest of the state. Jackson County prosecutors charged M1 in only $28.9 \%$ of the intentional homicide cases they prosecuted. The difference across statistical regions is highly statistically significant. In contrast, prosecutors in St. Louis City charged M1 in $85.5 \%$ of their intentional homicide cases. Apart from Jackson County, prosecutors in every other geographic category had an M1 charging rate above 50 percent, with a statewide average of $59.0 \%$. Given the low M1 charging rate in Jackson County, it is not surprising that prosecutors in that county secured M1 convictions at a much lower rate than the rest of the state. Only $10.5 \%$ of the Jackson County cases yielded M1 convictions, compared to a statewide average of $23.0 \%$.

197 Jackson County includes some areas that are outside the geographic limits of Kansas City, but Kansas City accounts for the bulk of the population and land area of Jackson County.

$198 \quad$ MSA stands for "metropolitan statistical area." As defined by the U.S. census bureau, any county with a population density of at least 1000 people per square mile is part of an MSA. Aside from St. Louis City and Jackson County, there are twenty counties in Missouri that are within an MSA.

199 We use census 2000 data to determine the percentage of nonwhite adults in each county. Unfortunately, we cannot limit the sample to citizens, as these data are not available, and so our estimate of the percentage of nonwhite jurors may be biased if immigrants are more likely to be nonwhite than the general public. Missouri does not have a large immigrant population, so this bias is likely to be small.

200 Consistent with standard statistical practice, "NS" signifies "Not Significant"; "+" signifies a pvalue of 0.10 or less; "**" indicates a p-value of 0.05 or less; “**” indicates a p-value of 0.01 or less; and “***” indicates a p-value of 0.001 or less. A p-value is a measure of how likely it is that one would obtain results at least as skewed as those shown even if the differences were, in fact, simply random variation. A p-value of 0.05 or less is generally considered to be statistically significant, and evidence of a relationship between the two variables at issue (for example, the relationship between geographic region and M1 charging decisions found in Table 6.3(A), column 1). 
Table 6.2(A) shows that, after separating St. Louis City and Jackson County from other urban counties, there are no significant differences between rural and urban/suburban (MSA) counties. Prosecutors in rural and MSA counties charged M1 at approximately the same rate $(58.5 \%$ and $59.1 \%$, respectively), and secured M1 convictions at approximately the same rate $(25.9 \%$ and $27.4 \%$, respectively). While it appears that prosecutors in MSA counties were more likely than their rural counterparts to withdraw an M1 charge, this result was not statistically significant. In contrast, jurors in rural counties were more likely than their MSA counterparts to reject an M1 charge proferred by a prosecutor, and this difference is statistically significant.

Table 6.2(A)

M1 Charging and Sentencing, Rural vs. Urban

\begin{tabular}{|c|c|c|c|c|c|c|}
\hline & $\begin{array}{c}\text { Prosecutor } \\
\text { Charged } \\
\text { M1 } \\
\text { (1) } \\
* * *\end{array}$ & $\begin{array}{c}\text { Prosecutor } \\
\text { Withdrew } \\
\text { M1 Charge } \\
\text { (2) } \\
\text { (NS) }\end{array}$ & $\begin{array}{c}\text { Pros. Took } \\
\text { M1 Charge } \\
\text { to Trial } \\
\text { (3) } \\
\text { (NS) }\end{array}$ & $\begin{array}{l}\text { Jury/Judge } \\
\text { Convicted of } \\
\text { Lesser } \\
\text { Charge } \\
\text { (4) } \\
* * *\end{array}$ & $\begin{array}{c}\text { M1 } \\
\text { Convictions } \\
\text { After M1 } \\
\text { Charge } \\
\text { (5) } \\
* * *\end{array}$ & $\begin{array}{c}\text { Total M1 } \\
\text { Convictions } \\
* * *(5)\end{array}$ \\
\hline $\begin{array}{l}\text { SL City } \\
\text { (262 Cases) }\end{array}$ & $\begin{array}{l}85.5 \% \\
(262)\end{array}$ & $\begin{array}{l}50.9 \% \\
(224)\end{array}$ & $\begin{array}{c}46.4 \% \\
(224)\end{array}$ & $\begin{array}{c}39.4 \% \\
(104)\end{array}$ & $\begin{array}{l}30.8 \% \\
(224)\end{array}$ & $\begin{array}{l}26.3 \% \\
(262)\end{array}$ \\
\hline $\begin{array}{l}\text { Jackson } \\
\text { (228 Cases) }\end{array}$ & $\begin{array}{l}28.9 \% \\
(228)\end{array}$ & $\begin{array}{c}53.0 \% \\
(66)\end{array}$ & $\begin{array}{c}45.5 \% \\
(66)\end{array}$ & $\begin{array}{c}23.3 \% \\
(30)\end{array}$ & $\begin{array}{c}36.4 \% \\
(66)\end{array}$ & $\begin{array}{l}10.5 \% \\
(228)\end{array}$ \\
\hline $\begin{array}{l}\text { MSA } \\
\text { Counties } \\
(274 \text { Cases })\end{array}$ & $\begin{array}{l}59.1 \% \\
(274)\end{array}$ & $\begin{array}{c}47.5 \% \\
(162)\end{array}$ & $\begin{array}{c}40.7 \% \\
(162)\end{array}$ & $\begin{array}{c}15.2 \% \\
(66)\end{array}$ & $\begin{array}{l}46.3 \% \\
(162)\end{array}$ & $\begin{array}{c}27.4 \% \\
(274)\end{array}$ \\
\hline $\begin{array}{l}\text { Rural } \\
\text { Counties } \\
\text { (282 Cases) }\end{array}$ & $\begin{array}{l}58.5 \% \\
(282)\end{array}$ & $\begin{array}{r}41.8 \% \\
(165)\end{array}$ & $\begin{array}{l}43.6 \% \\
(165)\end{array}$ & $\begin{array}{c}31.9 \% \\
(72)\end{array}$ & $\begin{array}{l}44.2 \% \\
(165)\end{array}$ & $\begin{array}{c}25.9 \% \\
(282)\end{array}$ \\
\hline $\begin{array}{l}\text { Total } \\
(1046 \\
\text { Cases) }\end{array}$ & $\begin{array}{l}59.0 \% \\
(1046)\end{array}$ & $\begin{array}{l}47.8 \% \\
(617)\end{array}$ & $\begin{array}{c}44.1 \% \\
(617)\end{array}$ & $\begin{array}{l}29.8 \% \\
(272)\end{array}$ & $\begin{array}{l}39.1 \% \\
(617)\end{array}$ & $\begin{array}{l}23.0 \% \\
(1046)\end{array}$ \\
\hline
\end{tabular}


Table 6.2(B)

\section{M1 Charging and Sentencing, Demographics of Jury Pool}

\begin{tabular}{|c|c|c|c|c|c|c|}
\hline & $\begin{array}{c}\text { Prosecutor } \\
\text { Charged } \\
\text { M1 } \\
(1) \\
* * *\end{array}$ & $\begin{array}{c}\text { Prosecutor } \\
\text { Withdrew } \\
\text { M1 Charge } \\
\text { (2) } \\
\text { (NS) }\end{array}$ & $\begin{array}{l}\text { Pros. Took } \\
\text { M1 Charge } \\
\text { to Trial } \\
\text { (3) } \\
\text { (NS) }\end{array}$ & $\begin{array}{c}\text { Jury/Judge } \\
\text { Convicted } \\
\text { of Lesser } \\
\text { Charge } \\
(4) \\
* *\end{array}$ & $\begin{array}{c}\text { M1 } \\
\text { Convictions } \\
\text { After M1 } \\
\text { Charge } \\
(5) \\
* *\end{array}$ & $\begin{array}{c}\text { Total M1 } \\
\text { Convictions } \\
* * *\end{array}$ \\
\hline $\begin{array}{l}\text { SL City } \\
(57 \% \text { non- } \\
\text { white) } \\
\text { ( } 262 \text { Cases) }\end{array}$ & $\begin{array}{l}85.5 \% \\
(262)\end{array}$ & $\begin{array}{l}50.9 \% \\
(224)\end{array}$ & $\begin{array}{l}46.4 \% \\
(224)\end{array}$ & $\begin{array}{l}39.4 \% \\
(104)\end{array}$ & $\begin{array}{l}30.8 \% \\
(224)\end{array}$ & $\begin{array}{l}26.3 \% \\
(262)\end{array}$ \\
\hline $\begin{array}{l}\text { Jackson } \\
(32 \% \text { non- } \\
\text { white }) \\
(228 \text { Cases) } \\
\end{array}$ & $\begin{array}{l}28.9 \% \\
(228)\end{array}$ & $\begin{array}{c}53.0 \% \\
(66)\end{array}$ & $\begin{array}{c}45.5 \% \\
(66)\end{array}$ & $\begin{array}{c}23.3 \% \\
(30)\end{array}$ & $\begin{array}{c}36.4 \% \\
(66)\end{array}$ & $\begin{array}{l}10.5 \% \\
(228)\end{array}$ \\
\hline $\begin{array}{l}\text { J Pool 10- } \\
30 \% \text { Non- } \\
\text { white } \\
(204 \text { Cases) }\end{array}$ & $\begin{array}{l}59.3 \% \\
(204)\end{array}$ & $\begin{array}{l}44.6 \% \\
(121)\end{array}$ & $\begin{array}{c}43.8 \% \\
(121)\end{array}$ & $\begin{array}{c}17.0 \% \\
(53)\end{array}$ & $\begin{array}{l}47.9 \% \\
(121)\end{array}$ & $\begin{array}{l}28.4 \% \\
(204)\end{array}$ \\
\hline $\begin{array}{l}\text { J Pool 5- } \\
10 \% \text { Non- } \\
\text { white } \\
\text { (169 Cases) }\end{array}$ & $\begin{array}{l}55.0 \% \\
(169)\end{array}$ & $\begin{array}{c}40.9 \% \\
(93)\end{array}$ & $\begin{array}{c}44.1 \% \\
(93)\end{array}$ & $\begin{array}{c}17.1 \% \\
(41)\end{array}$ & $\begin{array}{l}51.6 \% \\
(93)\end{array}$ & $\begin{array}{c}28.4 \% \\
(169)\end{array}$ \\
\hline $\begin{array}{l}\text { J Pool 0-5\% } \\
\text { Non-white } \\
\text { (183 Cases) }\end{array}$ & $\begin{array}{l}61.7 \% \\
(183)\end{array}$ & $\begin{array}{c}47.8 \% \\
(113)\end{array}$ & $\begin{array}{l}38.9 \% \\
(113)\end{array}$ & $\begin{array}{c}38.6 \% \\
(44)\end{array}$ & $\begin{array}{l}37.2 \% \\
(113)\end{array}$ & $\begin{array}{l}23.0 \% \\
(183)\end{array}$ \\
\hline $\begin{array}{l}\text { Total } \\
\text { (1046 Cases) }\end{array}$ & $\begin{array}{l}59.0 \% \\
(1046) \\
\end{array}$ & $\begin{array}{c}47.8 \% \\
(617) \\
\end{array}$ & $\begin{array}{c}44.1 \% \\
(617) \\
\end{array}$ & $\begin{array}{l}29.8 \% \\
(272) \\
\end{array}$ & $\begin{array}{l}39.1 \% \\
(617) \\
\end{array}$ & $\begin{array}{l}23.0 \% \\
(1046) \\
\end{array}$ \\
\hline
\end{tabular}

Table 6.2(B) presents results based upon jury pool demographics. As noted in the Table, the jury pool in St. Louis City is $57.0 \%$ non-white, and the jury pool in Jackson County is $32.3 \%$ non-white. Thus, one could divide the five geographic categories in Table 6.2(B) into three groups: those with a high percentage of non-whites in the jury pool (St. Louis City and Jackson County), those with a medium percentage (5-30\%), and those with a low percentage $(0-5 \%){ }^{201}$ Viewed in this way, it is evident that counties with a medium percentage of non-whites in the jury pool have the highest M1 conviction rate, measured as a percentage of the M1 charges. ${ }^{202}$ Counties in the $5-10 \%$ range have

201

Aside from St. Louis City and Jackson County, there are only four counties in the state with jury pools that are more than twenty percent non-white. They are: Pemiscot County (29.4\%), Pulaski County (24.3\%), Saint Louis County (24.0\%), and Mississippi County (22.7\%). Of these four, Saint Louis County is an MSA county and the others are rural counties.

${ }_{202}$ If one measures the M1 conviction rate as a percentage of the total cases, Jackson is an outlier, as noted above. Here, though, we focus on the M1 conviction rate as a percentage of the M1 charges, which is the percentage in column 5 . 
an M1 conviction rate of $51.6 \%$, and those in the $10-30 \%$ range have an M1 conviction rate of $47.9 \%$. In contrast, counties with a low percentage of non-whites in the jury pool $(0-5 \%)$, and those with a high percentage of non-whites (St. Louis and Jackson), all have M1 conviction rates between 30 and 38 percent. Interestingly, the high M1 conviction rate for counties with a medium non-white population appears to be largely a function of jury decision-making, rather than aggressive charging by prosecutors. The jurors in these counties were much more likely than their counterparts in other counties to return an M1 conviction instead of convicting the defendant of a lesser included offense. This is further bolstered by the result that there are no statistically significant differences across geographics regions in the prosecutor's decision to withdraw M1 charges or in the rate at which prosecutors took M1 charges to trial. The two primary decision points that demonstrate geographic disparities are the initial M1 charging decision and the jury's decision to reject the M1 charge at trial.

Table 6.2(C) shows that the higher M1 conviction rate for counties with a moderate percentage of non-whites in the jury pool applies to both rural and MSA counties. Using a 5\% cut-off to divide the rural counties into two groups, ${ }^{203}$ Table $6.2(\mathrm{C})$ shows that rural counties with a non-white population in the $5-30 \%$ range have an M1 conviction rate of $51.9 \%$. In contrast, rural counties with a non-white population below five percent have an M1 conviction rate of only 37.2\%. For MSA counties (other than St. Louis and Jackson), the difference is less pronounced, but not unimportant. MSA counties with a non-white population in the 10-30\% range have an M1 conviction rate of $50.0 \%$, compared to a $42.5 \%$ rate for MSA counties with a non-white population below ten percent. ${ }^{204}$

203 We use a 5\% cut-off to divide rural counties, and a 10\% cut-off to divide MSA counties, primarily to ensure an adequate number of cases in each group. If we used a 5\% cut-off for MSA counties, the total number of cases in the 0-5 category would be very small. Similarly, if we used a $10 \%$ cut-off to divide rural counties, the total number of cases in the 10-30 category would be quite small.

204 This pattern of differences is highly statistically significant. 
Table 6.2(C)

M1 vs. M2, Combine Rural/Urban and Jury Pool Demographics

\begin{tabular}{|c|c|c|c|c|c|c|}
\hline & $\begin{array}{c}\text { Prosecutor } \\
\text { Charged } \\
\text { M1 } \\
(1) \\
* * *\end{array}$ & $\begin{array}{l}\text { Prosecutor } \\
\text { Withdrew } \\
\text { M1 Charge } \\
\text { (2) } \\
\text { (NS) }\end{array}$ & $\begin{array}{l}\text { Pros. Took } \\
\text { M1 Charge } \\
\text { to Trial } \\
\text { (3) } \\
\text { (NS) }\end{array}$ & $\begin{array}{c}\text { Jury/Judge } \\
\text { Convicted } \\
\text { of Lesser } \\
\text { Charge } \\
(4) \\
* * *\end{array}$ & $\begin{array}{c}\text { M1 } \\
\text { Convictions } \\
\text { After M1 } \\
\text { Charge } \\
(5) \\
* * *\end{array}$ & $\begin{array}{c}\text { Total M1 } \\
\text { Convictions } \\
* * *\end{array}$ \\
\hline $\begin{array}{l}\text { SL City } \\
\text { (57\% non- } \\
\text { white) } \\
(262 \text { Cases) }\end{array}$ & $\begin{array}{l}85.5 \% \\
(262)\end{array}$ & $\begin{array}{l}50.9 \% \\
(224)\end{array}$ & $\begin{array}{l}46.4 \% \\
(224)\end{array}$ & $\begin{array}{c}39.4 \% \\
(104)\end{array}$ & $\begin{array}{l}30.8 \% \\
(224)\end{array}$ & $\begin{array}{l}26.3 \% \\
(262)\end{array}$ \\
\hline $\begin{array}{l}\text { Jackson } \\
\text { ( } 32 \% \text { non- } \\
\text { white) } \\
\text { ( } 228 \text { Cases) }\end{array}$ & $\begin{array}{l}28.9 \% \\
(228)\end{array}$ & $\begin{array}{c}53.0 \% \\
(66)\end{array}$ & $\begin{array}{c}45.5 \% \\
(66)\end{array}$ & $\begin{array}{c}23.3 \% \\
(30)\end{array}$ & $\begin{array}{l}36.4 \% \\
(66)\end{array}$ & $\begin{array}{l}10.5 \% \\
(228)\end{array}$ \\
\hline $\begin{array}{l}\text { MSA, } 10-30 \% \\
\text { Non-white } \\
\text { (128 Cases) }\end{array}$ & $\begin{array}{c}64.1 \% \\
(128)\end{array}$ & $\begin{array}{c}43.9 \% \\
(82)\end{array}$ & $\begin{array}{c}43.9 \% \\
(82)\end{array}$ & $\begin{array}{c}13.9 \% \\
(36)\end{array}$ & $\begin{array}{l}50.0 \% \\
(82)\end{array}$ & $\begin{array}{c}32.0 \% \\
(128)\end{array}$ \\
\hline $\begin{array}{l}\text { MSA, } 0-10 \% \\
\text { Non-white } \\
\text { (146 Cases) }\end{array}$ & $\begin{array}{l}54.8 \% \\
(146)\end{array}$ & $\begin{array}{c}51.2 \% \\
(80)\end{array}$ & $\begin{array}{c}37.5 \% \\
(80)\end{array}$ & $\begin{array}{c}16.7 \% \\
(30)\end{array}$ & $\begin{array}{l}42.5 \% \\
(80)\end{array}$ & $\begin{array}{c}23.3 \% \\
(146)\end{array}$ \\
\hline $\begin{array}{l}\text { Rural, 5-30\% } \\
\text { Non-white } \\
\text { (146 Cases) }\end{array}$ & $\begin{array}{l}54.1 \% \\
(146)\end{array}$ & $\begin{array}{c}38.0 \% \\
(79)\end{array}$ & $\begin{array}{c}46.8 \% \\
(79)\end{array}$ & $\begin{array}{c}21.6 \% \\
(37)\end{array}$ & $\begin{array}{l}51.9 \% \\
(79)\end{array}$ & $\begin{array}{c}28.1 \% \\
(146)\end{array}$ \\
\hline $\begin{array}{l}\text { Rural, } 0-5 \% \\
\text { Non-white } \\
\text { (136 Cases) }\end{array}$ & $\begin{array}{l}63.2 \% \\
(136)\end{array}$ & $\begin{array}{c}45.3 \% \\
(86)\end{array}$ & $\begin{array}{c}40.7 \% \\
(86)\end{array}$ & $\begin{array}{l}42.9 \% \\
(35)\end{array}$ & $\begin{array}{c}37.2 \% \\
(86)\end{array}$ & $\begin{array}{c}23.5 \% \\
(136)\end{array}$ \\
\hline $\begin{array}{l}\text { Total } \\
\text { (1046 Cases) }\end{array}$ & $\begin{array}{l}59.0 \% \\
(1046)\end{array}$ & $\begin{array}{c}47.8 \% \\
(617)\end{array}$ & $\begin{array}{c}44.1 \% \\
(617)\end{array}$ & $\begin{array}{c}29.8 \% \\
(272)\end{array}$ & $\begin{array}{l}39.1 \% \\
(617)\end{array}$ & $\begin{array}{l}23.0 \% \\
(1046)\end{array}$ \\
\hline
\end{tabular}

One possible explanation for the data is that M1 conviction rates are highest in areas that have the greatest racial tension. It is plausible to suggest that racial tension is low in counties where the population is virtually all white $(0-5 \%)$, and in counties where non-whites constitute a majority, or a substantial minority, of the population (St. Louis and Jackson). In contrast, racial tension may be greatest in counties with an intermediate level of non-white population. ${ }^{205}$ While this Article cannot answer this question directly, Section $\mathrm{C}$ investigates the interaction of geography with race-of-defendant and race-ofvictim. First, however, Section B describes the results of the analysis of race-of-victim and race-of-defendant effects.

205 The combined lack of interracial homicides and the small number of venue changes (both of which are ways to try to answer this question) make testing this hypothesis directly quite difficult. 


\section{B. Racial Disparities}

Traditionally, empirical investigations of racial disparities in murder convictions have broken down disparities by both race of the defendant, race of the victim, and their interaction. This Section follows this framework; Tables 6.3(A) through 6.3(C) detail the results. Because the racial identities of defendants and victims are only known in our small sample, we use this smaller dataset to explore the potential racial disparities in M1 outcomes. Relying on the smaller sample implies that some large absolute differences in outcomes will not be statistically significant; that is, they may have resulted from our random sampling rather than from the decisions made in individual cases. Thus, these tables also indicate the statistical significance of the differences: the top row of each table notes whether the disparities in outcomes are statistically significant across races. ${ }^{206}$ In addition, because of our sampling plan, where we oversampled death-noticed cases relative to other homicide cases, each cell contains the weighted average of the appropriate case outcome. This is an unbiased estimate of the true percentage in the larger database.

The disparities in processing M1 charges based upon race of the defendant are not generally statistically significant. Table 6.3(A) provides the details. Focusing first on the initial decision to charge M1, Table 6.3(A) demonstrates that there is no evidence of a racial disparity based upon the race of the defendant. Prosecutors charge M1 about 55\% to $60 \%$ of the time. Prosecutors charging other-race defendants charge M1 less often (28.1\% of the time), but with a small number of other-race defendants, overall, this could be due to chance variation in our small sample; there is no evidence of a statistically significant difference between the charging rates. There is also no evidence of a race-ofdefendant disparity in the percentage of cases in which the prosecutor withdraws an M1 charge; for white and black defendants, this happens about $40.4 \%$ and $46.5 \%$ of the time,

206 The significance level is, in some sense, a measure of the likelihood that the observed difference in percentages was too extreme to be caused by chance. More exactly, it is the probability that a deviation from the null hypothesis as at least large as the observed deviation would be observed. In this case, the null hypothesis is that race is independent from charging practices. The significance level is calculated based on a Pearson Chi-squared test of independence. See Alan Agresti, Categorical Data Analysis (2002) for details. Pearson Chi-Squared tests are a good approximation of an exact test when the expected number of cases within each cell is greater than 5; there are some cases where the expected number of cases is less than 5 . We mention this in the text when relevant, and perform exact tests, which do not suffer from this problem, whenever possible. 
respectively. Prosecutors withdrew M1 charges against other-race defendants less often (18\%), but, again, with only 5 other-race defendants charged with M1, this difference is not statistically significant. And, despite differences in the percentage of other-race defendants who go to trial facing M1 charges, these differences are also statistically insignificant.

Table 6.3(A): M1 vs. M2, Race of Defendant

\begin{tabular}{|c|c|c|c|c|c|c|}
\hline & $\begin{array}{c}\text { Prosecutor } \\
\text { Charged } \\
\text { M1 } \\
\text { (1) } \\
\text { NS }\end{array}$ & $\begin{array}{c}\text { Prosecutor } \\
\text { Withdrew } \\
\text { M1 Charge } \\
\text { (2) } \\
\text { NS }\end{array}$ & $\begin{array}{c}\text { Pros. Took } \\
\text { M1 Charge } \\
\text { to Trial } \\
\text { (3) } \\
\text { NS }\end{array}$ & $\begin{array}{c}\text { Jury/Judge } \\
\text { Convicted } \\
\text { of Lesser } \\
\text { Charge } \\
\text { (4) } \\
+\end{array}$ & $\begin{array}{c}\text { M1 } \\
\text { Convictions } \\
\text { After M1 } \\
\text { Charge } \\
\text { (5) } \\
\text { NS }\end{array}$ & $\begin{array}{c}\text { Total M1 } \\
\text { Convictions } \\
\text { NS }\end{array}$ \\
\hline $\begin{array}{l}\text { White } \\
\text { Defendant } \\
\text { (122 Cases) }\end{array}$ & $\begin{array}{l}55.0 \% \\
(122)\end{array}$ & $\begin{array}{c}40.4 \% \\
(98)\end{array}$ & $\begin{array}{c}44.2 \% \\
(98)\end{array}$ & $\begin{array}{c}43.0 \% \\
(43)\end{array}$ & $\begin{array}{c}40.7 \% \\
(98)\end{array}$ & $\begin{array}{c}22.3 \% \\
(122)\end{array}$ \\
\hline $\begin{array}{l}\text { Black } \\
\text { Defendant } \\
\text { (116 Cases) }\end{array}$ & $\begin{array}{c}58.3 \% \\
(116)\end{array}$ & $\begin{array}{c}46.5 \% \\
(83)\end{array}$ & $\begin{array}{c}47.3 \% \\
(83)\end{array}$ & $\begin{array}{c}24.9 \% \\
(45)\end{array}$ & $\begin{array}{c}41.7 \% \\
(83)\end{array}$ & $\begin{array}{c}24.3 \% \\
(116)\end{array}$ \\
\hline $\begin{array}{l}\text { Other-race } \\
\text { Defendant }{ }^{207} \\
(9 \text { Cases })\end{array}$ & $\begin{array}{c}28.1 \% \\
(9)\end{array}$ & $\begin{array}{c}18.0 \% \\
(5)\end{array}$ & $\begin{array}{c}82.0 \% \\
(5)\end{array}$ & $\begin{array}{c}78.0 \% \\
\text { (3) }\end{array}$ & $\begin{array}{c}18.0 \% \\
(5)\end{array}$ & $\begin{array}{c}5.1 \% \\
(9)\end{array}$ \\
\hline $\begin{array}{l}\text { Total } \\
\text { (247 Cases) }\end{array}$ & $\begin{array}{l}55.8 \% \\
(247)\end{array}$ & $\begin{array}{c}43.6 \% \\
(186)\end{array}$ & $\begin{array}{c}46.8 \% \\
(186)\end{array}$ & $\begin{array}{c}33.3 \% \\
(91)\end{array}$ & $\begin{array}{l}40.8 \% \\
(186)\end{array}$ & $\begin{array}{c}22.8 \% \\
(247)\end{array}$ \\
\hline
\end{tabular}

There is some evidence of racial differences in the rate at which the factfinder convicts a defendant of a lesser charge in an M1 trial. White defendants are almost twice as likely to be convicted of a lesser charge than black defendants (43.0\% versus $24.9 \%$ lesser charge conviction rates). In the final analysis, however, there is no statistically significant race-of-defendant disparity in the proportion of M1 convictions. Thus, throughout the homicide case decision tree, there is little evidence that the decisions of the prosecutor or the judge/jury create disparities between defendants based on their race.

Table 6.3(B) provides estimates of outcome probabilities by race-of-victim. Here, there are no statistically significant disparities based upon race-of-victim. Prosecutors initially charged M1 about 55\% of the time and withdrew those charges about $40-50 \%$ of the time. While there is slight variation across race-of-victim in these

207 "Other-race" defendants are Hispanic or Asian. There were no individuals in the small sample identified as Native American either as defendants or as victims. 
percentages, the differences are not statistically significant. ${ }^{208}$ Finally, there is no evidence of a disparity in the rate at which cases yielded M1 convictions, either in the subset of cases that went to trial or in all homicide cases. Overall, there is no evidence of race-of-victim disparities in homicide decisions regarding M1 charging.

Table 6.3(B): M1 vs. M2, Race of Victim

\begin{tabular}{|c|c|c|c|c|c|c|}
\hline & $\begin{array}{c}\text { Prosecutor } \\
\text { Charged } \\
\text { M1 } \\
(1) \\
\text { NS } \\
\end{array}$ & $\begin{array}{c}\text { Prosecutor } \\
\text { Withdrew } \\
\text { M1 Charge } \\
\text { (2) } \\
\text { NS }\end{array}$ & $\begin{array}{c}\text { Pros. Took } \\
\text { M1 Charge } \\
\text { to Trial } \\
\text { (3) } \\
\text { NS }\end{array}$ & $\begin{array}{c}\text { Jury/Judge } \\
\text { Convicted of } \\
\text { Lesser } \\
\text { Charge } \\
(4) \\
\text { NS } \\
\end{array}$ & $\begin{array}{c}\text { M1 } \\
\text { Convictions } \\
\text { After M1 } \\
\text { Charge } \\
\text { (5) } \\
\text { NS } \\
\end{array}$ & $\begin{array}{c}\text { Total M1 } \\
\text { Convictions } \\
\text { NS }\end{array}$ \\
\hline $\begin{array}{l}\text { White } \\
\text { Victim(s) } \\
\text { (149 Cases) }\end{array}$ & $\begin{array}{c}52.3 \% \\
(141)\end{array}$ & $\begin{array}{c}40.5 \% \\
(116)\end{array}$ & $\begin{array}{c}45.8 \% \\
(116)\end{array}$ & $\begin{array}{c}27.8 \% \\
(53)\end{array}$ & $\begin{array}{c}46.8 \% \\
(116)\end{array}$ & $\begin{array}{c}24.7 \% \\
(141)\end{array}$ \\
\hline $\begin{array}{l}\text { Black } \\
\text { Victim(s) } \\
\text { (87 Cases) }\end{array}$ & $\begin{array}{c}59.9 \% \\
(82)\end{array}$ & $\begin{array}{c}49.1 \% \\
(64)\end{array}$ & $\begin{array}{c}45.0 \% \\
(64)\end{array}$ & $\begin{array}{c}31.4 \% \\
(34)\end{array}$ & $\begin{array}{c}36.6 \% \\
(64)\end{array}$ & $\begin{array}{c}21.9 \% \\
(82)\end{array}$ \\
\hline $\begin{array}{l}\text { Other-race } \\
\text { Victim(s) } \\
\text { (9 Cases) }\end{array}$ & $\begin{array}{l}46.1 \% \\
(9)\end{array}$ & $\begin{array}{c}5.5 \% \\
(6)\end{array}$ & $\begin{array}{c}89.0 \% \\
(6)\end{array}$ & $\begin{array}{c}87.6 \% \\
\text { (4) }\end{array}$ & $\begin{array}{c}16.5 \% \\
(6)\end{array}$ & $\begin{array}{l}7.6 \% \\
(9)\end{array}$ \\
\hline $\begin{array}{l}\text { Total } \\
\text { (247 Cases) }\end{array}$ & $\begin{array}{l}55.8 \% \\
(247)\end{array}$ & $\begin{array}{c}43.6 \% \\
(186)\end{array}$ & $\begin{array}{c}46.8 \% \\
(186)\end{array}$ & $\begin{array}{c}33.3 \% \\
(91)\end{array}$ & $\begin{array}{l}40.8 \% \\
(186)\end{array}$ & $\begin{array}{c}22.8 \% \\
(247)\end{array}$ \\
\hline
\end{tabular}

To investigate potential racial disparities further, Table 6.3(C) presents the data broken out by both race-of-defendant and race-of-victim. Because most homicides in Missouri involve defendants and victims of the same race, investigating the disparities based on these two variables separately sometimes masks which variable is more important. Put another way, because of the strong correlation between defendant's race and victim's race, a disparity across race-of-defendant may secondarily cause a disparity across race-of-victim, and vice versa. Investigating the interaction between defendant race and victim race can parse which of these two variables is more important. In addition, studies of death penalty disparities have often found that the interaction of raceof-defendant and race-of-victim is more than the sum of its parts; that is, that the disparities seen in one variable (race-of-defendant) depend on the other (race-of-victim). Table 6.3(C) demonstrates that this is true to some extent in M1 prosecution as well.

208 Cases involving other-race victims have lower rates of M1 charges and the withdrawal of M1 charges, but with only 8 such cases, the differences are not statistically significant. 
Table 6.3(C): M1 vs. M2, Combined Race of Defendant / Race of Victim

\begin{tabular}{|c|c|c|c|c|c|c|}
\hline & $\begin{array}{c}\text { Prosecutor } \\
\text { Charged } \\
\text { M1 } \\
(1) \\
\text { NS }\end{array}$ & $\begin{array}{c}\text { Prosecutor } \\
\text { Withdrew } \\
\text { M1 Charge } \\
\text { (2) } \\
\text { NS }\end{array}$ & $\begin{array}{c}\text { Pros. Took } \\
\text { M1 Charge } \\
\text { to Trial } \\
\text { (3) } \\
\text { NS }\end{array}$ & $\begin{array}{c}\text { Jury/Judge } \\
\text { Convicted } \\
\text { of Lesser } \\
\text { Charge } \\
\text { (4) } \\
+\end{array}$ & $\begin{array}{c}\text { M1 } \\
\text { Convictions } \\
\text { After Charge } \\
\text { (5) } \\
\text { NS }\end{array}$ & $\begin{array}{c}\text { Total M1 } \\
\text { Convictions } \\
\text { (6) } \\
\text { NS }\end{array}$ \\
\hline $\begin{array}{l}\text { White } \\
\text { Defendant } \\
\text { White Victim } \\
\text { (115 Cases) }\end{array}$ & $\begin{array}{l}53.7 \% \\
(115)\end{array}$ & $\begin{array}{c}40.0 \% \\
(92)\end{array}$ & $\begin{array}{c}43.6 \% \\
(92)\end{array}$ & $\begin{array}{c}39.2 \% \\
(40)\end{array}$ & $\begin{array}{l}42.9 \% \\
(92)\end{array}$ & $\begin{array}{l}23.1 \% \\
(115)\end{array}$ \\
\hline $\begin{array}{l}\text { White } \\
\text { Defendant } \\
\text { Black Victim } \\
\text { (4 Cases) }\end{array}$ & $\begin{array}{c}100 \% \\
(4)\end{array}$ & $\begin{array}{c}50.0 \% \\
(4)\end{array}$ & $\begin{array}{l}50 \% \\
(4)\end{array}$ & $\begin{array}{l}87.6 \% \\
(2)\end{array}$ & $\begin{array}{l}6.2 \% \\
(4)\end{array}$ & $\begin{array}{l}6.2 \% \\
(4)\end{array}$ \\
\hline $\begin{array}{l}\text { Black } \\
\text { Defendant } \\
\text { White Victim } \\
\text { (31 Cases) }\end{array}$ & $\begin{array}{c}52.7 \% \\
(31)\end{array}$ & $\begin{array}{c}41.5 \% \\
(22)\end{array}$ & $\begin{array}{c}51.4 \% \\
(22)\end{array}$ & $\begin{array}{l}2.7 \% \\
(12)\end{array}$ & $\begin{array}{l}57.1 \% \\
(22)\end{array}$ & $\begin{array}{c}30.0 \% \\
(31)\end{array}$ \\
\hline $\begin{array}{l}\text { Black } \\
\text { Defendant } \\
\text { Black Victim } \\
\text { (84 Cases) }\end{array}$ & $\begin{array}{c}59.4 \% \\
(84)\end{array}$ & $\begin{array}{c}49.3 \% \\
(60)\end{array}$ & $\begin{array}{c}44.7 \% \\
(60)\end{array}$ & $\begin{array}{c}27.3 \% \\
(32)\end{array}$ & $\begin{array}{c}38.5 \% \\
(60)\end{array}$ & $\begin{array}{c}22.9 \% \\
(84)\end{array}$ \\
\hline $\begin{array}{l}\text { Other } \\
\text { Combinations } \\
\text { (13 Cases) }\end{array}$ & $\begin{array}{c}36.3 \% \\
(13)\end{array}$ & $\begin{array}{l}9.9 \% \\
(8)\end{array}$ & $\begin{array}{c}85.1 \% \\
(8)\end{array}$ & $\begin{array}{c}85.5 \% \\
(5)\end{array}$ & $\begin{array}{c}19.8 \% \\
(8)\end{array}$ & $\begin{array}{l}7.2 \% \\
(13)\end{array}$ \\
\hline $\begin{array}{l}\text { Total } \\
\text { ( } 247 \text { Cases) }\end{array}$ & $\begin{array}{l}55.8 \% \\
(247)\end{array}$ & $\begin{array}{c}43.6 \% \\
(186)\end{array}$ & $\begin{array}{c}46.8 \% \\
(186)\end{array}$ & $\begin{array}{c}33.3 \% \\
(91)\end{array}$ & $\begin{array}{l}40.8 \% \\
(186)\end{array}$ & $\begin{array}{c}22.8 \% \\
(247)\end{array}$ \\
\hline
\end{tabular}

Consistent with Tables 6.3(A) and (B), there is no statistically significant disparity based on the combination of race-of-defendant and race-of-victim in the initial charging decision, the decision to withdraw an M1 charge, or the decision to pursue a trial on M1 charges. Focusing on the next decision point, however, demonstrates a marginally statistically significant racial disparity in the percentage of cases in which the factfinder convicts the defendant of a lesser homicide charge. Factfinders convicted white defendants who killed white victims of a lesser charge $39.2 \%$ of the time, compared to $27.3 \%$ of the time for black defendants who killed black victims. While the number of cases for interracial homicides taken to M1 trial was quite small, they also tell an interesting story. White defendants who killed black victims had only a $12.4 \%$ chance of being convicted of M1 at trial, whereas black defendants who killed white victims had a $97.3 \%$ chance of being convicted of M1 at trial. 
Overall, the primary racial disparity in the homicide prosecution decision tree appears during the trial, in the factfinder's decision to convict on M1 or on a lesser homicide charge. This disparity does not remain when looking at the entire process as a whole; there is no statistically significant disparity in M1 convictions by race. While this disparity is only marginally statistically significant, the clear trend in the data, which demonstrates more leniency toward white defendants and those who kill black victims, is worrisome overall.

\section{Interaction Effects}

To conclude this analysis of M1 charging and conviction patterns in Missouri, Table 6.4 presents logistic regressions of each decision on multiple variables at once, rather than separating the variables to investigate individual disparities. As a descriptive matter, a logistic regression of several variables at once demonstrates which variables have larger disparities, and which disparities are more likely to be a by-product of another disparity (for example, the disparity in race-of-victim as a by-product of a disparity in race-of-defendant). For these reasons, it is important to investigate the interaction among variables. Documenting disparities based upon individual variables, as the earlier tables do, is also important because it demonstrates what disparities the system creates across these critical fault lines in our society. For example, geographic disparities in charging and sentencing practices are troublesome in general, and should therefore be investigated. However, geographic disparities that lead to racial disparities are, perhaps, even more worrisome, because of the historical legacy of discrimination in the criminal justice system. The fact that one can control for racial disparities by including geography as a variable does not negate the overall impact of racial differences; it simply suggests that geographic differences may be causing racial disparities. 
Table 6.4: M1 vs. M2, Interaction of Racial and Geographic Differences

\begin{tabular}{|c|c|c|c|c|c|c|}
\hline & $\begin{array}{c}\text { Prosecutor } \\
\text { Charged } \\
\text { M1 } \\
(\mathbf{1}) \\
\mathbf{R}^{2}=\mathbf{0 . 0 9}\end{array}$ & $\begin{array}{c}\text { Prosecutor } \\
\text { Withdrew } \\
\text { M1 Charge } \\
(2) \\
\mathbf{R}^{2}=\mathbf{0 . 1 0}\end{array}$ & $\begin{array}{c}\text { Pros. } \\
\text { Took M1 } \\
\text { Charge to } \\
\text { Trial } \\
(3) \\
\mathbf{R}^{2}=\mathbf{0 . 0 9} \\
\end{array}$ & $\begin{array}{c}\text { Jury/Judge } \\
\text { Convicted of } \\
\text { Lesser } \\
\text { Charge } \\
(4) \\
\mathbf{R}^{2}=0.31 \\
\end{array}$ & $\begin{array}{c}\text { M1 } \\
\text { Convictions } \\
\text { After M1 } \\
\text { Charge } \\
(5) \\
\mathbf{R}^{2}=0.09 \\
\end{array}$ & $\begin{array}{c}\text { Total M1 } \\
\text { Convictions } \\
\quad(6) \\
\\
\mathbf{R}^{2}=0.06 \\
\end{array}$ \\
\hline $\begin{array}{l}\text { Baseline: } \\
\text { MSA with 10- } \\
30 \% \text { non- } \\
\text { white jury } \\
\text { pool; White } \\
\text { Defendant, } \\
\text { White Victim }\end{array}$ & 1 & 1 & 1 & 1 & 1 & 1 \\
\hline $\begin{array}{l}\text { White } \\
\text { Defendant } \\
\text { Black Victim } \\
\text { (4 Cases) }\end{array}$ & $\begin{array}{l}\infty \\
(4)\end{array}$ & $\begin{array}{l}1.7 \\
(4)\end{array}$ & $\begin{array}{l}1.1 \\
(4)\end{array}$ & $\begin{array}{l}\infty^{209} \\
(2)\end{array}$ & $\begin{array}{l}0.3^{*} \\
(4)\end{array}$ & $\begin{array}{l}0.4 \\
(4)\end{array}$ \\
\hline $\begin{array}{l}\text { Black } \\
\text { Defendant } \\
\text { White Victim } \\
\text { (31 Cases) }\end{array}$ & $\begin{array}{c}1.1 \\
(31)\end{array}$ & $\begin{array}{c}1.2 \\
(22)\end{array}$ & $\begin{array}{c}1.1 \\
(22)\end{array}$ & $\begin{array}{c}0.01 * * \\
(12)\end{array}$ & $\begin{array}{l}2.8 \\
(22)\end{array}$ & $\begin{array}{c}2.0 \\
(31)\end{array}$ \\
\hline $\begin{array}{l}\text { Black } \\
\text { Defendant } \\
\text { Black Victim } \\
\text { (84 Cases) }\end{array}$ & $\begin{array}{l}1.0 \\
(84)\end{array}$ & $\begin{array}{l}2.2+ \\
(60)\end{array}$ & $\begin{array}{c}0.6 \\
(60)\end{array}$ & $\begin{array}{c}0.08^{* *} \\
(32)\end{array}$ & $\begin{array}{r}1.5 \\
(60)\end{array}$ & $\begin{array}{c}1.2 \\
(84)\end{array}$ \\
\hline $\begin{array}{l}\text { Other Racial } \\
\text { Combinations } \\
\text { (13 cases) }\end{array}$ & $\begin{array}{c}0.5 \\
(13)\end{array}$ & $\begin{array}{c}0.2+ \\
(8)\end{array}$ & $\begin{array}{c}8.0+ \\
(8)\end{array}$ & $\begin{array}{l}2.7 \\
(5)\end{array}$ & $\begin{array}{l}0.5 \\
(8)\end{array}$ & $\begin{array}{c}0.3 \\
(13)\end{array}$ \\
\hline $\begin{array}{l}\text { SL City } \\
\text { (46 Cases) }\end{array}$ & $\begin{array}{l}2.0 \\
(46)\end{array}$ & $\begin{array}{l}7.1^{*} \\
(39)\end{array}$ & $\begin{array}{l}0.2^{*} \\
(39)\end{array}$ & $\begin{array}{c}1.9 \\
(18)\end{array}$ & $\begin{array}{l}0.2^{*} \\
(39)\end{array}$ & $\begin{array}{l}0.4+ \\
(46)\end{array}$ \\
\hline $\begin{array}{l}\text { Jackson } \\
\text { (39 Cases) }\end{array}$ & $\begin{array}{l}0.3^{*} \\
(39)\end{array}$ & $\begin{array}{c}3.5 \\
(15) \\
\end{array}$ & $\begin{array}{c}0.4 \\
(15) \\
\end{array}$ & $\begin{array}{l}0.3 \\
(8)\end{array}$ & $\begin{array}{r}0.5 \\
(15) \\
\end{array}$ & $\begin{array}{l}0.3^{*} \\
(39) \\
\end{array}$ \\
\hline $\begin{array}{l}\text { MSA, 0-10\% } \\
\text { Non-white } \\
\text { (45 Cases) }\end{array}$ & $\begin{array}{c}0.6 \\
(45)\end{array}$ & $\begin{array}{c}14.6^{*} \\
(34)\end{array}$ & $\begin{array}{l}0.1^{*} \\
(34)\end{array}$ & $\begin{array}{c}0 \\
(12)\end{array}$ & $\begin{array}{r}0.6 \\
(34)\end{array}$ & $\begin{array}{c}0.4 \\
(45)\end{array}$ \\
\hline $\begin{array}{l}\text { Rural, 5-30\% } \\
\text { Non-white } \\
\text { (45 Cases) }\end{array}$ & $\begin{array}{c}0.9 \\
(45)\end{array}$ & $\begin{array}{c}4.4 \\
(38)\end{array}$ & $\begin{array}{c}0.2 \\
(38)\end{array}$ & $\begin{array}{l}0.3 \\
(20)\end{array}$ & $\begin{array}{r}0.7 \\
(38)\end{array}$ & $\begin{array}{c}0.7 \\
(45)\end{array}$ \\
\hline $\begin{array}{l}\text { Rural, } 0-5 \% \\
\text { Non-white } \\
\text { (35 Cases) }\end{array}$ & $\begin{array}{c}1 \\
(35)\end{array}$ & $\begin{array}{c}5.1 \\
(30)\end{array}$ & $\begin{array}{c}0.2 \\
(30)\end{array}$ & $\begin{array}{c}0.02 * * \\
(13)\end{array}$ & $\begin{array}{c}1.2 \\
(30)\end{array}$ & $\begin{array}{c}1.1 \\
(35)\end{array}$ \\
\hline
\end{tabular}

Table 6.4 presents logistic regressions of critical decision points. Logistic regressions estimate the "odds ratio" of a case with the given attributes (for example, a case from Saint Louis City) compared with a baseline case. The odds ratio is defined as

209 Because all cases in this category were treated the same way, the model cannot estimate an odds ratio. As the odds are $100 \%$ to $0 \%$, they are infinite. Similarly, for cases in which the odds are $0 \%$ to $100 \%$, the odds ratio is 0 , which is also indeterminate (because logistic regressions actually estimate natural logartihm of odds ratios, and the logarithm of zero is indeterminate). 
the odds of an outcome for a case with given attributes divided by the odds of an outcome for the baseline cases. For Table 6.4, the baseline case is a case from a county in an MSA with $10-30 \%$ non-white jury pool, with a white defendant and a white victim. Thus, the odds ratio of 2.0 for Saint Louis City in M1 charging means that the odds were 2.0 times higher that a white defendant with a white victim from Saint Louis City was charged with M1 as compared to the odds that a white defendant with a white victim from a county in an MSA with 10-30\% minority jury pool was charged with M1. Similarly, with an odds ratio of 1, the odds that a black defendant who killed a black victim was charged with M1 are the same as the odds that a white defendant who killed a white victim was charged with M1. In general, the closer the odds ratio is to one, the smaller the disparity in outcomes between the baseline and the variable at issue. One final note: in order to estimate accurately, logistic regression must have some variation in outcomes. If all cases of one type have the same outcome, logistic regression estimates that all potential cases of the same type would have that outcome - i.e., that one could predict perfectly what would happen in these cases. Thus, the logistic regression for the M1 charging decision cannot estimate the odds ratio of white defendants with black victims, because that value is infinite. In situations with a small number of cases (such as here, with only four such cases), one cannot rely on this estimate; it simply means that out of the four cases which had white defendants with black victims, all four defendants were charged with M1. It does not determine whether that fact is statistically significant. ${ }^{210}$

The results presented in Table 6.4 demonstrate that geography is the strongest predictor of M1 charging and conviction patterns; most of the statistically significant variables are geographic. First, in the decision to charge M1, Jackson County has odds of 0.3 to 1 compared to the baseline. Thus, the Jackson County disparity in M1 charging practice does not disappear when controlling for race; it is also of about the same magnitude as Table 6.2(C) suggests. Jackson County is the only factor listed in Table 6.4 that presents a statistically significant disparity in M1 charging patterns. With respect to the next decision point, whether the prosecutor withdrew the M1 charge, the primary disparity is between MSA counties with small minority jury pools and the baseline (of

210 Operationally, these four cases are dropped from the analysis, because they provide no information to help estimate other parameters, and because the model cannot estimate an infinite odds ratio. 
MSA counties with larger minority jury pools). Cases from MSA counties with $0-10 \%$ non-white jury pools had odds 14.6 times greater that the prosecutor withdrew the M1 charge. In addition, cases from Saint Louis City and cases with black defendants and black victims are more likely to be those in which the prosecutor withdrew the initial M1 charge. In Saint Louis City, the odds are 7 times greater than the baseline; for black defendants who kill black victims, the odds are 2.2 times as large as the baseline.

The final two columns of Table 6.4 present the odds ratios for M1 convictions. Geographic disparities, once again, are more significant than racial disparities. With respect to the odds of an M1 conviction after an initial M1 charge, cases from Saint Louis City had an odds ratio five times smaller than the baseline. This accentuates the disparity between St Louis City and other counties that exists without controlling for race: different distributions of racial groups hide a larger geographic disparity for Saint Louis City. This contrasts with Jackson County, where controlling for race does not change the geographic pattern much. While the odds ratio for cases with white defendants who kill black victims is also statistically significant, with only four cases of this type, the result is not terribly robust. The odds of an M1 conviction in Jackson County, based on the entire universe of cases, are 3.3 times smaller than the odds for the baseline case. For Saint Louis City, the odds of an M1 conviction, based on the universe of cases, are 2.5 times smaller than the baseline odds, although this result is only marginally statistically significant.

Overall, disparities across different counties are significant and enduring. Saint Louis City and Jackson County have significantly different charging and conviction patterns than other counties, even after controlling for race. With respect to racial disparities, there are large disparities in the rate at which judges and juries convict defendants of M1, rather than a lesser homicide charge. Focusing on race alone, white defendants and those defendants who kill black victims are less likely to be convicted of M1. 


\section{VII. \\ Life Versus Death}

As noted above, the Missouri homicide statute gives prosecutors extremely broad discretion to make charging decisions that largely determine which defendants should be sentenced to death, and which defendants should receive milder sentences. ${ }^{211}$ This broad discretion raises questions about whether the exercise of discretion by different prosecutors affects different groups of people in significantly disparate ways. Figure 7.1 depicts the process that produces decisions about which defendants live and which ones are sentenced to death. Part VII examines racial and geographic disparities at different points in this decision-making process, focusing on the four decision points identified in Figure 7.1. The first section examines geographic disparities and the second section analyzes racial disparities. The final section presents the results of a regression analysis that examines the interactions among these two sets of variables.

211 See supra notes__ and accompanying text. 


\section{FIGURE 7.1}

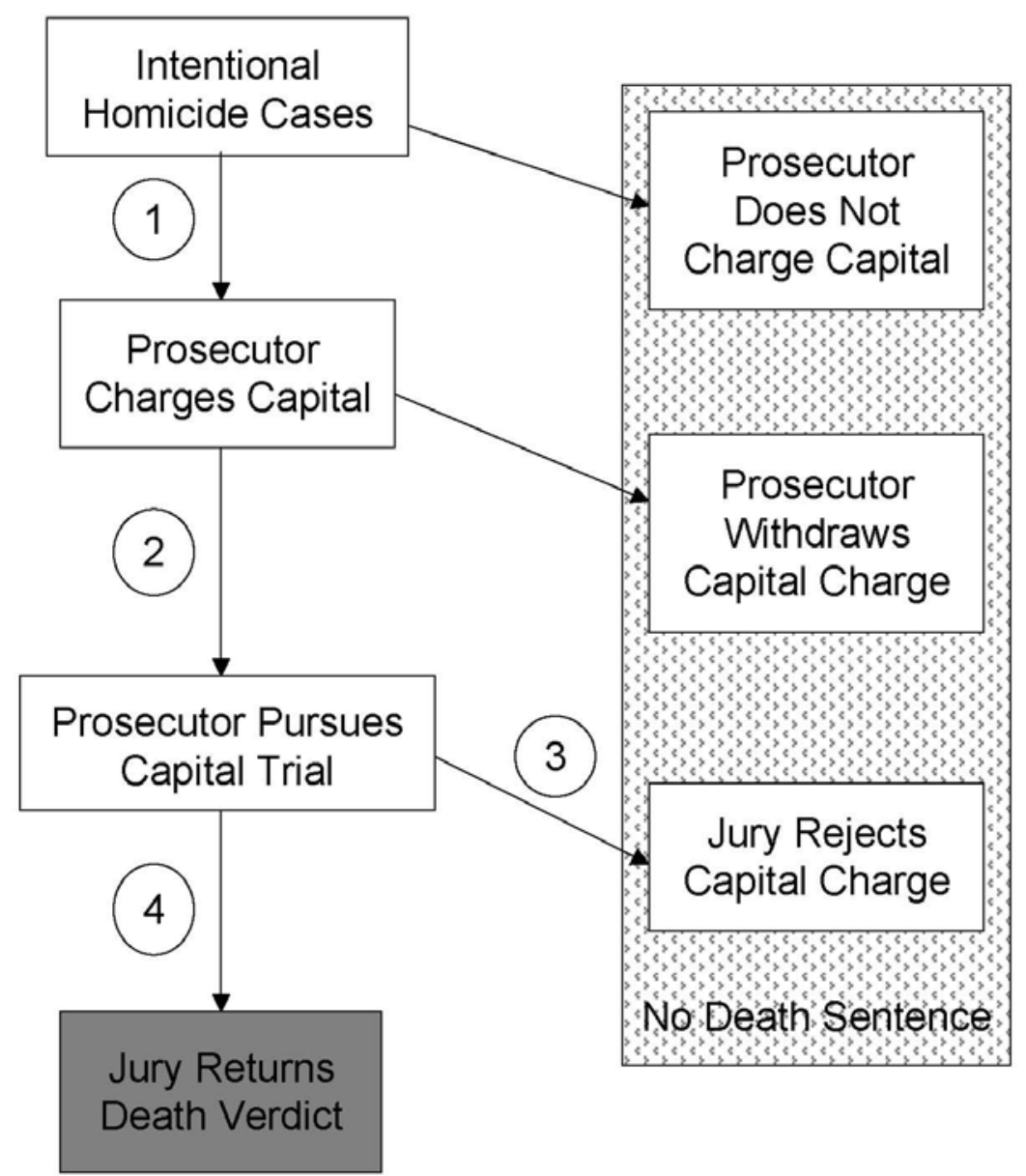

Following the convention in Part VI, the data tables throughout Part VII have column headings identical to the headings in Table 7.1 below. The headings of columns 1-4 correspond to the points labeled 1, 2, 3, and 4 in Figure 7.1. The percentages for the large database in the top row of table 7.1 are unweighted. The percentages for the small sample in the bottom row are based on weighted averages. The number in parentheses in each cell is the unweighted denominator; that is, the number of cases that the percentage in that cell is based upon. The percentages in columns 1-3 are calculated on the basis of the previous node in the decision tree. Thus, the percentage in the top row of column 1 means that prosecutors filed a capital charge in $12.7 \%$ of all intentional homicide cases. Similarly, the percentage in the top row of column 2 means that prosecutors pursued a capital trial in 39.8 percent of the cases that were charged as capital cases. Columns 4 and 5 display two different measurements for the frequency of death sentences. The 
denominator for the percentage in column 4 is the number of cases in which the prosecutor took a capital charge to trial. The denominator for the percentage in column 5 is the universe of all intentional homicide cases. We utilize the same format for all the remaining tables in Part VII to analyze geographic and racial disparities.

TABLE 7.1

\begin{tabular}{|l|c|c|c|c|c|}
\hline & $\begin{array}{c}\text { Prosecutor } \\
\text { Filed Capital } \\
\text { Charge } \\
\mathbf{( 1 )}\end{array}$ & $\begin{array}{c}\text { Prosecutor } \\
\text { Pursued } \\
\text { Capital Trial } \\
\mathbf{( 2 )}\end{array}$ & $\begin{array}{c}\text { Jury Rejected } \\
\text { Capital Charge } \\
\text { at Trial } \\
\mathbf{( 3 )}\end{array}$ & $\begin{array}{c}\text { Death } \\
\text { Sentences } \\
\text { After Capital } \\
\text { Trial } \\
\mathbf{( 4 )}\end{array}$ & $\begin{array}{c}\text { Total Death } \\
\text { Sentences } \\
\mathbf{( 5 )}\end{array}$ \\
\hline Large & $12.7 \%$ & $39.8 \%$ & $50.9 \%$ & $49.1 \%$ & $2.5 \%$ \\
Database & $(1046)$ & $(133)$ & $(53)$ & $(53)$ & $(1046)$ \\
(1046 Cases) & $13.0 \%$ & $39.4 \%$ & $48.0 \%$ & $52.0 \%$ & $2.7 \%$ \\
\hline Small & $(247)$ & $(127)$ & $(50)$ & $(50)$ & $(247)$ \\
Sample & & & & & \\
(247 Cases) & & & & & \\
\hline
\end{tabular}

\section{A. Geographic Disparity}

Tables 7.2(A) to 7.2(C) present data on geographic disparity in the process for deciding which defendants are convicted of first-degree murder. These tables follow the same rubric as in Part VI.A above.

Several aspects of the data in Table 7.2 are noteworthy. First, prosecutors in St. Louis City and Jackson County filed capital charges much less frequently than prosecutors in the rest of the state. In St. Louis, prosecutors charged capital in $6.5 \%$ of the intentional homicide cases; in Jackson, the comparable figure was $1.3 \%$. But in the rest of the state, prosecutors charged capital in roughly $20 \%$ of the intentional homicide cases. This pattern of differences is highly statistically significant. Prosecutors in St. Louis and Jackson also obtained capital convictions far less frequently than their counterparts in the rest of the state. St. Louis prosecutors obtained capital convictions in fewer than one-half of one percent of intentional homicide cases. Jackson prosecutors produced no capital convictions in more than 200 cases. In contrast, prosecutors in the rest of Missouri obtained capital convictions in about $4.5 \%$ of all intentional homicide cases. This pattern is highly statistically significant.

If one sets aside St. Louis City and Jackson County, and focuses on the rest of the state, other interesting points emerge. Table 7.2(A) shows that rural counties and MSA 
counties have fairly similar capital charging and sentencing rates. In contrast, Table 7.2(B) shows that there is greater variability across groups of counties if one utilizes the racial composition of the jury pool to divide counties into groups. Defendants in counties where the jury pool is $10-30 \%$ non-white were more than twice as likely to be sentenced to death as defendants in counties where the jury pool is $5-10 \%$ non-white. This difference does not correlate to differences in capital charging rates between the two groups: indeed, the charging rate in the $5-10 \%$ group was slightly higher. Rather, the difference in sentencing outcomes is primarily attributable to the fact that juries in the 5$10 \%$ counties were twice as likely to reject capital charges at trial as juries in the $10-30 \%$ counties.

Table 7.2(A)

Capital Charging and Death Sentences, Rural vs. Urban ${ }^{212}$

\begin{tabular}{|c|c|c|c|c|c|}
\hline & $\begin{array}{c}\text { Prosecutor } \\
\text { Filed Capital } \\
\text { Charge } \\
(1) \\
* * *\end{array}$ & $\begin{array}{c}\text { Prosecutor } \\
\text { Pursued } \\
\text { Capital Trial } \\
\text { (2) } \\
\text { NS }\end{array}$ & $\begin{array}{c}\text { Jury Rejected } \\
\text { Capital Charge } \\
\text { at Trial } \\
\text { (3) } \\
*\end{array}$ & $\begin{array}{c}\text { Death } \\
\text { Sentences } \\
\text { After Capital } \\
\text { Trial } \\
\text { (4) } \\
*\end{array}$ & $\begin{array}{c}\text { Total Death } \\
\text { Sentences } \\
(5) \\
* * *\end{array}$ \\
\hline $\begin{array}{l}\text { SL City } \\
\text { (262 Cases) }\end{array}$ & $\begin{array}{l}6.5 \% \\
(262) \\
\end{array}$ & $\begin{array}{c}47.1 \% \\
(17) \\
\end{array}$ & $\begin{array}{c}87.5 \% \\
(8) \\
\end{array}$ & $\begin{array}{c}12.5 \% \\
(8)\end{array}$ & $\begin{array}{l}0.4 \% \\
(262) \\
\end{array}$ \\
\hline $\begin{array}{l}\text { Jackson } \\
\text { (228 Cases) }\end{array}$ & $\begin{array}{l}1.3 \% \\
(228)\end{array}$ & $\begin{array}{c}66.7 \% \\
(3)\end{array}$ & $\begin{array}{c}100.0 \% \\
(2)\end{array}$ & $\begin{array}{c}0 \\
(2)\end{array}$ & $\begin{array}{c}0 \\
(228)\end{array}$ \\
\hline $\begin{array}{l}\text { MSA } \\
\text { Counties } \\
\text { (274 Cases) }\end{array}$ & $\begin{array}{l}17.9 \% \\
(274)\end{array}$ & $\begin{array}{c}36.7 \% \\
(49)\end{array}$ & $\begin{array}{c}44.4 \% \\
(18)\end{array}$ & $\begin{array}{l}55.6 \% \\
(18)\end{array}$ & $\begin{array}{l}3.6 \% \\
(274)\end{array}$ \\
\hline $\begin{array}{l}\text { Rural } \\
\text { Counties } \\
\text { (282 Cases) }\end{array}$ & $\begin{array}{l}22.7 \% \\
(282)\end{array}$ & $\begin{array}{c}39.1 \% \\
(64)\end{array}$ & $\begin{array}{c}40.0 \% \\
(25)\end{array}$ & $\begin{array}{l}60.0 \% \\
(25)\end{array}$ & $\begin{array}{l}5.3 \% \\
(282)\end{array}$ \\
\hline $\begin{array}{l}\text { Total } \\
\text { (1046 Cases) }\end{array}$ & $\begin{array}{l}12.7 \% \\
(1046 \\
\end{array}$ & $\begin{array}{c}39.8 \% \\
(133) \\
\end{array}$ & $\begin{array}{c}50.9 \% \\
(53)\end{array}$ & $\begin{array}{c}49.1 \% \\
(53)\end{array}$ & $\begin{array}{c}2.5 \% \\
(1046) \\
\end{array}$ \\
\hline
\end{tabular}

212 The statistical test used in Tables 7.2(A)-7.2(C) was Fisher's Exact test, which does not rely on large samples, but instead proves an exact estimate of the p-value. Throughout this Article, Fisher's Exact test was used whenever possible (because of some small cell counts); although because of the sampling scheme, the more general Pearson Chi-Squared Test was used for much of the small sample testing. 
Table 7.2(B)

Capital Charging and Death Sentences, Demographics of Jury Pool

\begin{tabular}{|c|c|c|c|c|c|}
\hline & $\begin{array}{c}\text { Prosecutor } \\
\text { Filed Capital } \\
\text { Charge } \\
(1) \\
* * *\end{array}$ & $\begin{array}{c}\text { Prosecutor } \\
\text { Pursued } \\
\text { Capital Trial } \\
\text { (2) } \\
\text { NS }\end{array}$ & $\begin{array}{c}\text { Jury Rejected } \\
\text { Capital Charge } \\
\text { at Trial } \\
\text { (3) } \\
*\end{array}$ & $\begin{array}{c}\text { Death } \\
\text { Sentences } \\
\text { After Capital } \\
\text { Trial } \\
\text { (4) } \\
*\end{array}$ & $\begin{array}{c}\text { Total Death } \\
\text { Sentences } \\
(5) \\
* * *\end{array}$ \\
\hline $\begin{array}{l}\text { SL City } \\
\text { (262 Cases) }\end{array}$ & $\begin{array}{l}6.5 \% \\
(262) \\
\end{array}$ & $\begin{array}{c}47.1 \% \\
(17)\end{array}$ & $\begin{array}{c}87.5 \% \\
(8)\end{array}$ & $\begin{array}{c}12.5 \% \\
(8)\end{array}$ & $\begin{array}{l}0.4 \% \\
(262)\end{array}$ \\
\hline $\begin{array}{l}\text { Jackson } \\
\text { (228 Cases) }\end{array}$ & $\begin{array}{l}1.3 \% \\
(228)\end{array}$ & $\begin{array}{c}66.7 \% \\
\text { (3) }\end{array}$ & $\begin{array}{l}100.0 \% \\
\text { (2) }\end{array}$ & $\begin{array}{c}0 \\
(2)\end{array}$ & $\begin{array}{c}0 \\
(228)\end{array}$ \\
\hline $\begin{array}{l}\text { Pop } 10-30 \% \\
\text { Non-white } \\
\text { (204 Cases) }\end{array}$ & $\begin{array}{l}19.1 \% \\
(204)\end{array}$ & $\begin{array}{c}48.7 \% \\
(39)\end{array}$ & $\begin{array}{c}31.6 \% \\
(19)\end{array}$ & $\begin{array}{c}68.4 \% \\
(19)\end{array}$ & $\begin{array}{l}6.4 \% \\
(204)\end{array}$ \\
\hline $\begin{array}{l}\text { Pop } 5-10 \% \\
\text { Non-white } \\
\text { (169 Cases) }\end{array}$ & $\begin{array}{l}21.3 \% \\
(169)\end{array}$ & $\begin{array}{c}38.9 \% \\
(36)\end{array}$ & $\begin{array}{c}64.3 \% \\
(14)\end{array}$ & $\begin{array}{c}35.7 \% \\
(14)\end{array}$ & $\begin{array}{l}3.0 \% \\
(169)\end{array}$ \\
\hline $\begin{array}{l}\text { Pop 0-5\% } \\
\text { Non-white } \\
\text { (183 Cases) }\end{array}$ & $\begin{array}{l}20.8 \% \\
(183)\end{array}$ & $\begin{array}{c}26.3 \% \\
(38)\end{array}$ & $\begin{array}{l}30 \% \\
(10)\end{array}$ & $\begin{array}{l}70.0 \% \\
(10)\end{array}$ & $\begin{array}{l}3.8 \% \\
(183)\end{array}$ \\
\hline $\begin{array}{l}\text { Total } \\
\text { (1046 Cases) }\end{array}$ & $\begin{array}{l}12.7 \% \\
(1046) \\
\end{array}$ & $\begin{array}{c}39.8 \% \\
(133) \\
\end{array}$ & $\begin{array}{c}50.9 \% \\
(53) \\
\end{array}$ & $\begin{array}{c}49.1 \% \\
(53) \\
\end{array}$ & $\begin{array}{c}2.5 \% \\
(1046) \\
\end{array}$ \\
\hline
\end{tabular}


Table 7.2(C)

Capital Charging and Death Sentences

Combine Rural/Urban and Jury Pool Demographics

\begin{tabular}{|c|c|c|c|c|c|}
\hline & $\begin{array}{c}\text { Prosecutor } \\
\text { Filed Capital } \\
\text { Charge } \\
\text { (1) } \\
* * *\end{array}$ & $\begin{array}{c}\text { Prosecutor } \\
\text { Pursued } \\
\text { Capital Trial } \\
\text { (2) } \\
\text { NS }\end{array}$ & $\begin{array}{c}\text { Jury Rejected } \\
\text { Capital Charge } \\
\text { at Trial } \\
\text { (3) } \\
*\end{array}$ & $\begin{array}{c}\text { Death } \\
\text { Sentences } \\
\text { After Capital } \\
\text { Trial } \\
\text { (4) } \\
*\end{array}$ & $\begin{array}{c}\text { Total Death } \\
\text { Sentences } \\
(5) \\
* * *\end{array}$ \\
\hline $\begin{array}{l}\text { SL City } \\
\text { (262 Cases) }\end{array}$ & $\begin{array}{l}6.5 \% \\
(262) \\
\end{array}$ & $\begin{array}{c}47.1 \% \\
(17)\end{array}$ & $\begin{array}{c}87.5 \% \\
(8)\end{array}$ & $\begin{array}{l}(12.5 \%) \\
(8 / 262)\end{array}$ & $\begin{array}{l}0.4 \% \\
(262) \\
\end{array}$ \\
\hline $\begin{array}{l}\text { Jackson } \\
\text { (228 Cases) }\end{array}$ & $\begin{array}{l}1.3 \% \\
(228)\end{array}$ & $\begin{array}{l}66.7 \% \\
(3)\end{array}$ & $\begin{array}{l}100.0 \% \\
(2)\end{array}$ & $\begin{array}{l}0 \\
(2)\end{array}$ & $\begin{array}{c}0 \\
(228)\end{array}$ \\
\hline $\begin{array}{l}\text { MSA, Pop } \\
10-30 \% \\
\text { Non-white } \\
\text { (128 Cases) }\end{array}$ & $\begin{array}{l}16.4 \% \\
(128)\end{array}$ & $\begin{array}{l}52.4 \% \\
(21)\end{array}$ & $\begin{array}{c}27.3 \% \\
(11)\end{array}$ & $\begin{array}{l}72.7 \% \\
(11)\end{array}$ & $\begin{array}{l}6.2 \% \\
(128)\end{array}$ \\
\hline $\begin{array}{l}\text { MSA, Pop 0- } \\
10 \% \text { Non- } \\
\text { white } \\
\text { (146 Cases) }\end{array}$ & $\begin{array}{l}19.2 \% \\
(146)\end{array}$ & $\begin{array}{c}25.0 \% \\
(28)\end{array}$ & $\begin{array}{l}71.4 \% \\
(7)\end{array}$ & $\begin{array}{l}28.6 \% \\
(7)\end{array}$ & $\begin{array}{l}1.4 \% \\
(146)\end{array}$ \\
\hline $\begin{array}{l}\text { Rural, Pop 5- } \\
30 \% \text { Non- } \\
\text { white } \\
\text { (146 Cases) }\end{array}$ & $\begin{array}{l}24.0 \% \\
(146)\end{array}$ & $\begin{array}{c}45.7 \% \\
(35)\end{array}$ & $\begin{array}{c}3.7 \% \\
(16)\end{array}$ & $\begin{array}{l}56.2 \% \\
(16)\end{array}$ & $\begin{array}{l}6.2 \% \\
(146)\end{array}$ \\
\hline $\begin{array}{l}\text { Rural, Pop 0- } \\
5 \% \text { Non- } \\
\text { white } \\
\text { (136 Cases) }\end{array}$ & $\begin{array}{l}21.3 \% \\
(136)\end{array}$ & $\begin{array}{l}31.0 \% \\
(29)\end{array}$ & $\begin{array}{l}33.3 \% \\
(9)\end{array}$ & $\begin{array}{l}66.7 \% \\
(9)\end{array}$ & $\begin{array}{l}4.4 \% \\
(136)\end{array}$ \\
\hline $\begin{array}{l}\text { Total } \\
\text { (1046 Cases) }\end{array}$ & $\begin{array}{l}12.7 \% \\
(1046)\end{array}$ & $\begin{array}{l}39.8 \% \\
(133)\end{array}$ & $\begin{array}{c}50.9 \% \\
(53)\end{array}$ & $\begin{array}{l}49.1 \% \\
(53)\end{array}$ & $\begin{array}{l}2.5 \% \\
(1046)\end{array}$ \\
\hline
\end{tabular}

Table 7.2(C) displays significant variability across groups of counties other than Jackson and St. Louis City. The initial capital charging rates, while ranging only from a low of $16.4 \%$ (MSA, 10-30) to a high of $24.0 \%$ (rural, 5-30), demonstrate a statistically significant relationship between geographic region and capital charging. In contrast, while there is much more variability in the rate at which prosecutors took capital charges to trial (column 2), this pattern is not statistically significant, and there is no evidence to suggest that the variability across geographic regions is systematic. The differences in the rates at which juries rejected capital charges at trial (column 3), however, are also statistically significant. Excluding Jackson and SL City, these range from a high of 71.4\% (MSA 0-10) to just 27.3\% (MSA 10-30). Overall, MSA counties with a jury pool that is $0-10 \%$ non-white had the lowest capital trial rate $(25.0 \%)$ and the highest jury rejection 
rate $(71.4 \%)$, which resulted in the lowest capital conviction rate $(1.4 \%)$. In contrast, MSA counties with a jury pool that is $10-30 \%$ non-white had the highest capital trial rate $(52.4 \%)$ and the lowest jury rejection rate $(27.3 \%)$, resulting in a $6.2 \%$ capital conviction rate. As the statistical significance demonstrates, this final pattern in death sentences is not a product of random variation; these differences are due to geography.

In sum, if one compares St. Louis City and Jackson County to the rest of the state, it appears that their very low capital conviction rates can be attributed to low initial capital charging rates. In contrast, if one leaves aside St. Louis City and Jackson County and compares the remaining groups of counties to each other, it appears that differences in sentencing outcomes have more to do with jury behavior and downstream prosecutorial decisions, rather than the initial decision to charge a case as capital or noncapital.

\section{B. Racial Disparity}

Tables 7.3(A) through 7.3(C) present data on the racial disparities associated with the process of deciding which defendants are sentenced to death. Table 7.3(A) focuses on defendant's race as a fault line for disparities. Several noteworthy facts emerge from the results. First, all four decision points exhibit statistically significant disparities when comparing black versus white defendants, although adding other-race defendants decreases the power of the test sufficiently that overall, the differences across all races are not necessarily statistically significant. With $7.7 \%$ of black defendants facing a capital charge, they are about a third as likely to do so as white defendants, $21.2 \%$ of whom face a capital charge at some point during the prosecution. The rates at which prosecutors took capital charges to trial also vary significantly, in the opposite direction: white defendants are two-thirds as likely to face a capital trial after capital charges are filed than black defendants. Thus, many more white defendants face death penalty charges, but charges for these white defendants are more likely to be dropped, resulting in a statistically significant difference of $6.6 \%$ capital trial rate for white defendants versus $4.1 \%$ capital trial rate for black defendants. Exacerbating the impact of this disparity on death sentences is the fact that juries rejected capital charges more often for black defendants $(52.2 \%$ versus $40 \%)$. Overall, because of the higher original filing rate and the slightly 
higher jury sentencing rate, white defendants are twice as likely to be sentenced to death as black defendants.

\section{Table 7.3(A): Capital Charging and Death Sentences Race of Defendant}

\begin{tabular}{|c|c|c|c|c|c|}
\hline & $\begin{array}{c}\text { Prosecutor } \\
\text { Filed Capital } \\
\text { Charge } \\
(1) \\
* * *\end{array}$ & $\begin{array}{c}\text { Prosecutor } \\
\text { Pursued } \\
\text { Capital Trial } \\
(2) \\
* \\
\end{array}$ & $\begin{array}{c}\text { Jury Rejected } \\
\text { Capital Charge } \\
\text { at Trial } \\
\text { (3) } \\
\text { NS } \dagger \\
\end{array}$ & $\begin{array}{c}\text { Death } \\
\text { Sentences After } \\
\text { Capital Trial } \\
\text { (4) } \\
\text { NS } \dagger \\
\end{array}$ & $\begin{array}{c}\text { Total Death } \\
\text { Sentences } \\
(5) \\
\text { NS } \dagger \\
\end{array}$ \\
\hline $\begin{array}{l}\text { White } \\
\text { Defendant } \\
\text { (122 Cases) }\end{array}$ & $\begin{array}{c}21.2 \% \\
(122)\end{array}$ & $\begin{array}{c}31.2 \% \\
(80)\end{array}$ & $\begin{array}{c}40.0 \% \\
(25)\end{array}$ & $\begin{array}{l}60.0 \% \\
(25)\end{array}$ & $\begin{array}{l}4.0 \% \\
(122)\end{array}$ \\
\hline $\begin{array}{l}\text { Black } \\
\text { Defendant } \\
\text { (116 Cases) }\end{array}$ & $\begin{array}{l}7.7 \% \\
(116)\end{array}$ & $\begin{array}{c}53.5 \% \\
(43)\end{array}$ & $\begin{array}{c}52.2 \% \\
(23)\end{array}$ & $\begin{array}{l}47.8 \% \\
(23)\end{array}$ & $\begin{array}{l}2.0 \% \\
(116)\end{array}$ \\
\hline $\begin{array}{l}\text { Other-race } \\
\text { Defendant } \\
\text { (9 Cases) }\end{array}$ & $\begin{array}{c}10.1 \% \\
(9)\end{array}$ & $\begin{array}{c}50.0 \% \\
\text { (4) }\end{array}$ & $\begin{array}{c}100 \% \\
(2)\end{array}$ & $\begin{array}{l}0 \% \\
(2)\end{array}$ & $\begin{array}{c}0 \\
(9)\end{array}$ \\
\hline $\begin{array}{l}\text { Total } \\
\text { (247 Cases) }\end{array}$ & $\begin{array}{l}13.0 \% \\
(247)\end{array}$ & $\begin{array}{c}39.4 \% \\
(127)\end{array}$ & $\begin{array}{l}48 \% \\
(50) \\
\end{array}$ & $\begin{array}{l}52 \% \\
(50)\end{array}$ & $\begin{array}{l}2.7 \% \\
(247) \\
\end{array}$ \\
\hline
\end{tabular}

$\dagger$ Note that while the overall racial pattern is not statistically significant the difference between white victims and black victims is highly statistically significant (p-value $<0.001$ ); the inclusion of other-race defendants significantly lowers the power of the test.

Table 7.3(B) presents the data for the capital charging process broken out by race of victim. Similar to the race-of-defendant results, differences between cases with white victims and cases with black victims are statistically significant, even though overall, race-of-victim is not a statistically significant predictor of capital trial rates or death sentences after a capital trial. Starting with the initial decision to file a capital charge, however, significant disparities emerge. Prosecutors are less than half as likely to file a capital charge in cases that involve black victims ( $7.0 \%$ of the time) compared to cases that involve white victims (18.5\% of the time). Again, prosecutors are less likely to pursue a capital trial initially in cases with white victims, but jurors are more likely to sentence the defendant to death in these cases. These two effects counter-balance each other, leaving the relative percentage of death sentences about the same as the relative percentage of capital charges: just over two to one, with cases involving white victims imposing a death sentence $4.0 \%$ of the time, while cases involving black victims have a death sentence imposed $1.4 \%$ of the time. 
Table 7.3(B): Capital Charging and Death Sentences

Race of Victim(s)

\begin{tabular}{|c|c|c|c|c|c|}
\hline & $\begin{array}{c}\text { Prosecutor } \\
\text { Filed Capital } \\
\text { Charge } \\
\text { (1) } \\
* * *\end{array}$ & $\begin{array}{c}\text { Prosecutor } \\
\text { Pursued } \\
\text { Capital Trial } \\
\text { (2) } \\
\text { NS } \dagger\end{array}$ & $\begin{array}{c}\text { Jury Rejected } \\
\text { Capital Charge } \\
\text { at Trial } \\
\text { (3) } \\
+\dagger\end{array}$ & $\begin{array}{c}\text { Death } \\
\text { Sentences After } \\
\text { Capital Trial } \\
\text { (4) } \\
+\dagger\end{array}$ & $\begin{array}{c}\text { Total Death } \\
\text { Sentences } \\
\text { (5) } \\
\\
+†\end{array}$ \\
\hline $\begin{array}{l}\text { White } \\
\text { Victim(s) } \\
\text { (149 Cases) }\end{array}$ & $\begin{array}{l}18.5 \% \\
(149)\end{array}$ & $\begin{array}{c}34.7 \% \\
(92)\end{array}$ & $\begin{array}{c}37.5 \% \\
(32)\end{array}$ & $\begin{array}{l}62.5 \% \\
(32)\end{array}$ & $\begin{array}{l}4.0 \% \\
(149)\end{array}$ \\
\hline $\begin{array}{l}\text { Black } \\
\text { Victim(s) } \\
\text { (89 Cases) }\end{array}$ & $\begin{array}{l}7.0 \% \\
(89)\end{array}$ & $\begin{array}{c}51.6 \% \\
(31)\end{array}$ & $\begin{array}{c}62.5 \% \\
(16)\end{array}$ & $\begin{array}{c}37.5 \% \\
(16)\end{array}$ & $\begin{array}{l}1.4 \% \\
(89)\end{array}$ \\
\hline $\begin{array}{l}\text { Other-race } \\
\text { Victim(s) } \\
\text { (9 Cases) }\end{array}$ & $\begin{array}{c}10.1 \% \\
(9)\end{array}$ & $\begin{array}{c}50.0 \% \\
(4)\end{array}$ & $\begin{array}{c}100 \% \\
(2)\end{array}$ & $\begin{array}{l}0 \% \\
(2)\end{array}$ & $\begin{array}{c}0 \\
(9)\end{array}$ \\
\hline $\begin{array}{l}\text { Total } \\
\text { (247 Cases) }\end{array}$ & $\begin{array}{l}13.0 \% \\
(247) \\
\end{array}$ & $\begin{array}{c}39.4 \% \\
(127) \\
\end{array}$ & $\begin{array}{l}48 \% \\
(50)\end{array}$ & $\begin{array}{l}52 \% \\
(50) \\
\end{array}$ & $\begin{array}{l}2.7 \% \\
(247) \\
\end{array}$ \\
\hline
\end{tabular}

$\dagger$ Note that while the overall racial pattern is not statistically significant - or only marginally so - the difference between white victims and black victims is highly statistically significant (p-value $<0.001$ ); the inclusion of other-race defendants significantly lowers the power of the test.

As with homicide prosecution in general, defendant race and victim race disparities are strongly correlated because most homicides are intra-racial. Our study is no exception, with at least $80.6 \%$ of homicides involving defendants and victims of the same race. Table 7.3(C) presents the interaction of these two variables. Here, all of the decision points except the decision to pursue a capital trial after filing a capital charge demonstrate statistically significant racial disparities. First, with respect to the prosecutor's decision to file a capital charge, white defendants who kill white victims have the highest chance of facing a capital charge (21.6\%). The risk of facing a capital charge is only about $60 \%$ as high if the victim of a white defendant is black. Black defendants have an even lower risk. Following the pattern for white defendants, for cases with black defendants, the risk of a capital charge is almost $50 \%$ higher for those defendants who killed white victims.

Variations in the rates at which prosecutors decide to pursue a capital trial are not statistically significant. The rate at which juries imposed death sentences at trial, however, demonstrates significant racial disparities. If one disregards the one case where a white defendant killed a black victim, it is clear that black defendants who kill white victims are treated the most harshly, with a $75 \%$ chance of a death sentence after capital trial. This is more than twice as large as the $33.3 \%$ chance of a death sentence for black 
defendants with black victims. White defendants face a $60.9 \%$ chance of a death sentence after capital trial if their victim was white. Overall, the difference in death sentence rates is more than four-fold from the lowest probability of receiving a death sentence $(1.2 \%$ for black defendants with black victims) to the highest probability $(6.2 \%$, for white defendants with black victims). Interestingly, cross-race cases are treated more harshly than intra-race cases; defendants in cross-race cases receive death sentences in $4.9 \%$ of the cases, while defendants in intra-race cases receive a death sentence in only $2.8 \%$ of the cases. This result is only marginally significant, perhaps because of the small number of cross-race cases (31 total). Unfortunately, it is impossible to tell whether this finding would persist with a larger number of cross-race cases.

Table 7.3(C): Capital Charging and Death Sentences Race of Defendant and Race of Victim Combined

\begin{tabular}{|c|c|c|c|c|c|}
\hline & $\begin{array}{c}\text { Prosecutor } \\
\text { Filed Capital } \\
\text { Charge } \\
(1) \\
* * *\end{array}$ & $\begin{array}{c}\text { Prosecutor } \\
\text { Pursued } \\
\text { Capital Trial } \\
\text { (2) } \\
\text { NS }\end{array}$ & $\begin{array}{c}\text { Jury Rejected } \\
\text { Capital } \\
\text { Charge at } \\
\text { Trial } \\
\text { (3) } \\
* * *\end{array}$ & $\begin{array}{c}\text { Death } \\
\text { Sentences } \\
\text { After Capital } \\
\text { Trial } \\
(4) \\
* * *\end{array}$ & $\begin{array}{c}\text { Total Death } \\
\text { Sentences } \\
\text { (5) } \\
\\
*\end{array}$ \\
\hline $\begin{array}{l}\text { White } \\
\text { Defendant } \\
\text { White Victim } \\
\text { (115 Cases) }\end{array}$ & $\begin{array}{l}21.6 \% \\
(115)\end{array}$ & $\begin{array}{c}30.3 \% \\
(76)\end{array}$ & $\begin{array}{c}39.1 \% \\
(23)\end{array}$ & $\begin{array}{c}60.9 \% \\
(23)\end{array}$ & $\begin{array}{l}4.0 \% \\
(115)\end{array}$ \\
\hline $\begin{array}{l}\text { White } \\
\text { Defendant } \\
\text { Black Victim } \\
\text { (4 Cases) }\end{array}$ & $\begin{array}{c}12.4 \% \\
(4)\end{array}$ & $\begin{array}{l}50 \% \\
(2)\end{array}$ & $\begin{array}{l}0 \% \\
(1)\end{array}$ & $\begin{array}{l}100 \% \\
(1)\end{array}$ & $\begin{array}{l}6.2 \% \\
(4)\end{array}$ \\
\hline $\begin{array}{l}\text { Black } \\
\text { Defendant } \\
\text { White Victim } \\
\text { (31 Cases) }\end{array}$ & $\begin{array}{c}10.4 \% \\
(31)\end{array}$ & $\begin{array}{c}57.1 \% \\
(14)\end{array}$ & $\begin{array}{c}25.0 \% \\
(8)\end{array}$ & $\begin{array}{c}75.0 \% \\
(8)\end{array}$ & $\begin{array}{l}4.5 \% \\
(31)\end{array}$ \\
\hline $\begin{array}{l}\text { Black } \\
\text { Defendant } \\
\text { Black Victim } \\
\text { (84 Cases) }\end{array}$ & $\begin{array}{l}6.9 \% \\
(84)\end{array}$ & $\begin{array}{c}51.7 \% \\
(29)\end{array}$ & $\begin{array}{c}66.7 \% \\
(15)\end{array}$ & $\begin{array}{l}33.3 \% \\
(15)\end{array}$ & $\begin{array}{l}1.2 \% \\
(84)\end{array}$ \\
\hline $\begin{array}{l}\text { Other } \\
\text { Combinations } \\
\text { (13 Cases) }\end{array}$ & $\begin{array}{c}10.8 \% \\
(13)\end{array}$ & $\begin{array}{l}50 \% \\
(6)\end{array}$ & $\begin{array}{c}100 \% \\
(3)\end{array}$ & $\begin{array}{l}0 \% \\
(3)\end{array}$ & $\begin{array}{c}0 \% \\
(13)\end{array}$ \\
\hline $\begin{array}{l}\text { Total } \\
\text { (247 Cases) }\end{array}$ & $\begin{array}{l}13.0 \% \\
(247)\end{array}$ & $\begin{array}{c}39.4 \% \\
(127)\end{array}$ & $\begin{array}{l}48 \% \\
(50)\end{array}$ & $\begin{array}{l}52 \% \\
(50)\end{array}$ & $\begin{array}{l}2.7 \% \\
(247)\end{array}$ \\
\hline
\end{tabular}

Overall, the primary racial difference in capital charging is the difference across racial lines in intra-race cases. Homicides with white defendants and white victims are 
treated significantly more harshly than homicides with black defendants and black victims. This could be the product of geography -prosecutors in areas with large black populations are less likely to seek the death penalty, and juries from these locations are less likely to impose the death penalty. The next section turns to this question, investigating the interplay between race and geography.

\section{Interactions Between Variables}

As a final description of the disparities in treatment across cases, Table 7.4 presents the results of several logistic regressions, with the dependent variable of each regression being a decision point in Figure 7.1, and the independent variables being geography (as measured by both MSA and jury pool) and race (including both race-ofdefendant and race-of-victim). As with Table 6.4, the values presented in Table 7.4 are the odds ratio of the variable listed, as compared with the baseline.

Once again, geography trumps race as a relative explanation for the disparities seen; all of the racial disparities are statistically insignificant when controlling for geography. There is an apparent disparity in cases involving white defendants with black victims: all of the defendants who went to trial received a death sentence. However, with only four such cases in the sample, and only one that went to trial, there is not statistically significant evidence of a disparity between these cases and others; the same is true for the result that no cases received a death sentence if either the defendant or the victim was other-race. 
Table 7.4: Capital Charging and Death Sentences Interaction between Geography and Race

\begin{tabular}{|c|c|c|c|c|c|}
\hline & $\begin{array}{c}\text { Prosecutor } \\
\text { Filed Capital } \\
\text { Charge } \\
(\mathbf{1}) \\
\mathbf{R}^{2}=\mathbf{0 . 1 3} \\
\end{array}$ & $\begin{array}{c}\text { Prosecutor } \\
\text { Pursued } \\
\text { Capital Trial } \\
(2) \\
\mathbf{R}^{2}=\mathbf{0 . 0 5} \\
\end{array}$ & $\begin{array}{c}\text { Jury Rejected } \\
\text { Capital Charge } \\
\text { at Trial } \\
(3) \\
\mathbf{R}^{2}=0.28 \\
\end{array}$ & $\begin{array}{c}\text { Death } \\
\text { Sentences After } \\
\text { Capital Charge } \\
(\mathbf{4}) \\
\mathbf{R}^{2}=\mathbf{0 . 2 8} \\
\end{array}$ & $\begin{array}{c}\begin{array}{c}\text { Total Death } \\
\text { Sentences }\end{array} \\
\begin{array}{c}(5) \\
\mathbf{R}^{2}=0.14\end{array} \\
\end{array}$ \\
\hline $\begin{array}{l}\text { Baseline: } \\
\text { MSA with } \\
\text { 10-30\% non- } \\
\text { white jury } \\
\text { pool; White } \\
\text { Defendant; } \\
\text { White Victim }\end{array}$ & 1 & 1 & 1 & 1 & 1 \\
\hline $\begin{array}{l}\text { White } \\
\text { Defendant } \\
\text { Black Victim } \\
\text { (4 Cases) }\end{array}$ & 1.5 & 2.7 & 0 & $\infty$ & 17.4 \\
\hline $\begin{array}{l}\text { Black } \\
\text { Defendant } \\
\text { White Victim } \\
\text { (27 Cases) }\end{array}$ & 0.9 & 2.7 & 0.8 & 1.2 & 3.7 \\
\hline $\begin{array}{l}\text { Black } \\
\text { Defendant } \\
\text { Black Victim } \\
\text { (76 Cases) }\end{array}$ & 0.6 & 2.2 & 4.6 & 0.2 & 0.6 \\
\hline $\begin{array}{l}\text { Other-race } \\
\text { victim or } \\
\text { defendant } \\
\text { ( Cases) }\end{array}$ & 0.5 & 2.6 & $\infty$ & 0 & 0 \\
\hline $\begin{array}{l}\text { SL City } \\
\text { (262 Cases) }\end{array}$ & 0.5 & 0.7 & $28.5^{*}$ & $0.04 *$ & $0.04^{*}$ \\
\hline $\begin{array}{l}\text { Jackson } \\
\text { (228 Cases) }\end{array}$ & $0.06^{* * *}$ & 2.7 & $\infty$ & 0 & 0 \\
\hline $\begin{array}{l}\text { MSA, } 0-10 \% \\
\text { Non-white } \\
\text { (146 Cases) }\end{array}$ & 0.9 & 0.4 & $28.4+$ & $0.04+$ & $0.1^{*}$ \\
\hline $\begin{array}{l}\text { Rural, } 5-30 \% \\
\text { Non-white } \\
\text { (146 Cases) }\end{array}$ & 2.0 & 0.7 & 1.1 & 0.9 & 1.3 \\
\hline $\begin{array}{l}\text { Rural, } 0-5 \% \\
\text { Non-white } \\
\text { (136 Cases) }\end{array}$ & 1.4 & 0.9 & 2.4 & 0.4 & 0.8 \\
\hline
\end{tabular}

Most of the disparities that are statistically significant are based upon geography. The decision-making in Jackson County and Saint Louis City creates disparities in outcomes and process. The odds that a defendant in Jackson County faces a capital charge are sixteen times less ( 0.06 times more) than the odds for a baseline case. No death sentences were imposed in Jackson County during the period of the study. 
Prosecutors in St. Louis City are slightly less likely to file capital charges and pursue capital trials than prosecutors in the baseline case. However, juries reject capital charges in St. Louis City at very high rates, after controlling for race. A defendant from St. Louis City facing a capital trial has odds 28.5 times higher than the baseline of receiving a sentence less than death at trial. Overall, this translates into a much smaller risk of a death sentence in St Louis City - the odds of receiving a death sentence (out of all intentional homicides) are 25 times smaller than the odds of receiving a death sentence in a baseline county. Cases from MSA counties with small minority jury pools (0-10\%) also have this pattern: charging and trial practices are similar to other counties, but juries reject capital charges at a rate 28.4 times greater than the baseline rate. This is consistent with the findings in Table 7.2(C), which suggest that MSA counties with small minority jury pools, or very large minority jury pools (Jackson and St. Louis City) impose death sentences less frequently than other counties in Missouri.

In summary, geographic disparities endure after controlling for race-ofdefendant and race-of-victim, while race effects are no longer present, meaning that geography is better at explaining the capital decision-making process than race. With the important exception of Jackson County, the results suggest that differences in jury decision-making explain a significant portion of the final geographic disparities in death sentencing rates. 


\section{VIII \\ Conclusions and Recommendations}

Over the past few decades, numerous countries throughout the world have abolished capital punishment. Despite this global trend, there is broad public support for continued use of capital punishment in the United States. In light of that public support, we assume that Missouri, like other states in the U.S., will retain the death penalty as the ultimate criminal sanction for the foreseeable future. ${ }^{213}$ However, as the U.S. Supreme Court has stated, the Eighth Amendment requires that "capital punishment must be limited to those offenders who commit 'a narrow category of the most serious crimes' and whose extreme culpability makes them 'the most deserving of execution.",214 The preceding analysis suggests that the defendants who are sentenced to death in Missouri are not necessarily the most culpable, or those who commit the most serious crimes. Instead, the defendants who are sentenced to death are disproportionately those who commit their crimes in counties where prosecutors make aggressive use of capital punishment.

The underlying problem is the breadth of prosecutorial discretion. As the preceding analysis demonstrates, prosecutors in Missouri prosecuted about 800 deatheligible homicides between January 1997 and December 2001. Only about 50 of those cases led to capital trials. The current statute does not provide any criteria to guide prosecutors in selecting the 50 capital trials from the 800 death-eligible cases. Without clear statutory criteria to guide them, prosecutors in different counties exercise their discretion in very different ways. In Jackson County, prosecutors held capital trials in fewer than one-half of one percent of the intentional homicide cases they prosecuted. In Boone, Jasper and Pemiscot counties, though, prosecutors took capital charges to trial in more than fifteen percent of their cases.

The following recommendations are designed primarily to reduce disparities across counties in the implementation of capital punishment by limiting the class of death-eligible offenses. The recommendations are divided into two groups. The second

213 New Jersey recently became the first state to abolish the death penalty in over 50 years.

214 Roper v. Simmons, 543 U.S. 551, 568 (2005) (quoting Atkins v. Virginia, 536 U.S. 304, 319 (2002)). 
group of recommendations focuses exclusively on the statutory aggravating factors. The first group of recommendations addresses other issues.

\section{A. Recommendations That Do Not Relate to Statutory Aggravators}

1. Moratorium and Further Study: We assume that there is broad consensus that the death penalty should be reserved for the most serious crimes and the most culpable offenders. This study raises doubts about whether, in practice, capital punishment in Missouri actually conforms to that standard. Given the limitations we faced in collecting data about the implementation of capital punishment in Missouri, ${ }^{215}$ we recognize that the Missouri legislature may be hesitant to adopt statutory reforms without first commissioning a state-sponsored study to obtain more comprehensive data. We support the idea that there should be a state-sponsored study of capital punishment in Missouri. However, the present study has exposed problems that are sufficiently serious to warrant a legislatively imposed moratorium while a further study is being conducted.

2. Introduce a district attorney system in Missouri: For administrative purposes, Missouri is divided into 115 counties, each with its own chief prosecutor. This means that there are 115 independent decision-makers in Missouri, each of whom may have somewhat different views about capital punishment. This is a relatively large number compared to other important death penalty states. ${ }^{216}$ Other things being equal, a larger number of independent decision-makers increases the risk of geographic disparities across prosecutorial districts. Although Missouri has 115 counties, Missouri's judicial system is divided into 45 judicial districts, most of which encompass two or more counties. We recommend that the legislature consider adopting a district attorney system wherein the state would be divided into 45 prosecutorial districts with the same boundaries as the 45 judicial districts. By reducing the number of independent decisionmakers, this proposal would reduce the risk of geographic disparities across districts in the implementation of capital punishment.

\footnotetext{
215 See supra notes _ and accompanying text.

216 Two of the other leading death penalty states have a larger number of independent decision makers: Texas has 155 and Virginia has 120. However, most of the other leading death penalty states have fewer independent prosecutors. There are 88 in Ohio, 67 in Pennsylvania, 58 in California (the most populous state), 48 in Georgia, 41 in Alabama, 39 in North Carolina, 27 in Oklahoma and only 20 in Florida (the $4^{\text {th }}$ most populous state). Information from Steven M. Perry, Statistician, Bureau of Justice Statistics. www.oip.usdoj.gov/bjs.
} 
3. Amend the statutory definition of deliberation: Missouri defines the term "deliberation" to mean "cool reflection for any length of time no matter how brief.,"217 Under this definition, there is no meaningful distinction between first degree murder, which is death-eligible, and "knowing" second degree murder, which is not deatheligible. ${ }^{218}$ We recommend that the Missouri legislature revise the statutory definition of "deliberation" to require evidence of advance planning or a preconceived design before the killing occurs. We estimate that at least 84 percent of all cases in the large database are M1-eligible under the current statute. In contrast, we estimate that approximately 36 percent of those cases would be M1-eligible under the revised definition of "deliberation." 219

4. Proportionality Review: For every case that results in a death verdict, Missouri law requires the Supreme Court to consider "whether the sentence of death is excessive or disproportionate to the penalty imposed in similar cases." ${ }^{220}$ In practice, the Court conducts this proportionality review by comparing death cases to other death cases. ${ }^{221}$ This study suggests that proportionality review would be more meaningful if the Court compared death cases to non-death cases. We recommend that the Missouri Supreme Court should modify its practice in this regard, or that the legislature should amend the statute to require comparison of death cases to non-death cases.

\section{B. Recommendations Related to Statutory Aggravating Factors}

Section 565.032 of the Missouri Code lists seventeen different aggravating factors. Due to the sheer number of aggravators, and the breadth of certain aggravators, one or more statutory aggravating factors is present in approximately 90 percent of all M1-eligible cases. ${ }^{222}$ We recommend the following specific statutory changes to limit the number of cases that are death-eligible under the statute.

1. Eliminate or limit the "wantonly vile" aggravator. This aggravator is present in more than ninety percent of the M1-eligible small sample cases. It does not

V.A.M.S. 565.002(3).

See supra notes _ and accompanying text. See supra notes _ and accompanying text. V.A.M.S. $\S 565.035 .3(3)$.

See supra notes _ and accompanying text.

See supra Tables 5.4 and 5.7. 
satisfy the Zant $v$. Stephens requirement that aggravators must genuinely narrow the class of death-eligible offenses. The recommended solution is to eliminate this aggravator. An alternative approach would be to limit the aggravator so that it applies only to cases involving torture. For these purposes, the Missouri legislature could adopt the federal definition of "torture," which is codified in 18 U.S.C. $§ 2340 .{ }^{223}$

2. Limit the scope of the "felony murder" aggravator. As currently drafted, this aggravator is present in more than 50 percent of the small sample cases. The breadth of the aggravator is primarily attributable to the fact that it covers all murders committed in conjunction with a robbery, burglary, or drug crime. The legislature should narrow the scope of this aggravator to restrict its application to rape-murder cases. A slightly broader version would cover murders committed in conjunction with kidnapping and/or sodomy.

3. Limit the scope of the "for money" aggravator. As currently drafted, this aggravator is present in about 45 percent of the small sample cases. The breadth of this aggravator is primarily attributable to the fact that it covers all murders committed in conjunction with a theft offense. The legislature should narrow the scope of this aggravator so that it applies only to murder-for-hire cases; it should apply both to the person who pays and to the person who receives money for the commission of a murder. A slightly broader version would include cases where defendant kills a relative to obtain an inheritance, or to obtain insurance benefits.

4. Limit the scope of the "killing witness" aggravator. As currently drafted, this aggravator is present in about 48 percent of the small sample cases. The breadth of application stems from the fact that the statute applies whenever "the murdered individual was a witness or potential witness in any past or pending investigation or past or pending

223 Under the federal definition, an act does not qualify as "torture" unless it is "committed by a person acting under the color of law." 18 U.S.C. $§ 2340(1)$. We recommend that Missouri adopt the federal definition without the "color of law" requirement. 
prosecution." The legislature should narrow the scope of this aggravator so that it applies only in cases where the victim was a subpoenaed or potential witness in a criminal case where charges had already been filed.

5. Eliminate the "avoiding arrest" aggravator. As currently drafted, this aggravator is present in about 48 percent of the small sample cases. Because there is virtually a complete overlap between the cases covered by this aggravator, and the cases covered by the "killing witness" aggravator, there is no need to retain this as a separate aggravator. ${ }^{224}$ Moreover, the cases of greatest concern are covered by either the "escaped custody" or "concealing drug crime" aggravator.

6. Eliminate the "agent or employee" aggravator. As currently applied, this aggravator is present in about 41 percent of the small sample cases. The cases of greatest concern covered by this aggravator are the murder-for-hire cases, which are also covered by the "for money" aggravator. This aggravator also applies to other cases that involve concerted action among two or more co-defendants, but the fact of concerted action, without more, does not justify imposition of capital punishment.

7. Limit the scope of the "prior record" aggravator. As currently drafted, this aggravator applies not only to a person who has been convicted of M1; it also applies to anyone "who has one or more serious assaultive criminal convictions." 225 The Supreme Court has construed this factor broadly to apply even to a defendant with a prior conviction for second degree assault. ${ }^{226}$ The legislature should amend the statute to limit this aggravator to defendants with prior murder convictions.

224 See supra notes _ and accompanying text (discussing overlap between the "avoiding arrest" and "killing witness" aggravators).

$225 \quad$ V.A.M.S. 565.032.2(1).

226 See State v. Kinder, 942 S.W.2d 313 (Mo. 1997). 
Name of Student (Research Assistant)

I. Summary Information (Get copy of docket sheet in every case)

Name of Defendant

County

If Change of Venue, from which County? Attorney
Case Number

Circuit

Prosecuting

II. Charging/Disposition (Get copies of documents, as indicated on the instructions.)

Date of Indictment/Information

Defense Counsel (Pvt or PD)

Date of Disposition

Charge for Which D
Initial Charge (M1, M2, or VM)

Convicted/Pled

Jury Trial, Bench Trial, or Guilty Plea?

Sentence 
- If change of venue, to which county?

- If initially charged as murder first, and jury convicted on a lesser charge, did the prosecutor

present the first degree murder charge to the jury? 
III. Death Penalty Info: (Get copies of documents, as indicated on the instructions.)

Did Prosecutor seek death penalty at any time during prosecution?

How do we know that?

Did capital charge go to jury?

If not, why not?

If so, did jury return pro-death verdict?

IV. Additional Comments: 


\section{Instructions for Completing Form}

$\underline{\text { Part One }}$

Fill out part one completely, if possible. Please make a copy of the docket sheet in every case (if we don't already have the docket sheet.) Please check the case number against the OSCA print-out to make sure that the two numbers correspond. If the court files use one number, and the OSCA print-out has a different number, please list both numbers on the form.

In many cases, there will be more than one judge, prosecutor, and/or defense attorney. In each case, identify the presiding judge at the time of disposition, as well as the lead prosecutor and lead defense attorney at the time of disposition. If you are uncertain which person to list, then you may list more than one judge, prosecutor, etc. For defense attorneys, indicate whether the attorney is a private attorney or a public defender.

$\underline{\text { Part Two }}$

Under "initial charge," please write either "first degree murder," "second degree murder" or "voluntary manslaughter." Please do the same for the entry "charge for which D convicted/pled." If the defendant was convicted of or pled guilty to a lesser charge, include that information. Under "sentence," put either "death," "life without parole," or the number of years imprisonment for which defendant was sentenced. Please be sure to make copies of the indictment/information, any amendments to the indictment/information, any documents evidencing final conviction/sentence, and any documents evidencing a change of venue.

If a case is reversed on appeal and the defendant gets a new trial (or a new plea bargain), please complete a separate form for the new trial, staple the two forms together, and include a brief explanation in the "comments" section.

\section{Part Three}

The first question in part three - whether the prosecutor sought the death penalty at any time during the prosecution - may not be easy to answer. There are four possibilities:

- if the initial charge was second degree murder or lower, and the charge was never amended to first degree murder, then the answer is "no"

- if there is documentary evidence that the prosecutor did seek the death penalty at any time during the prosecution, then the answer is "yes," regardless of whether the prosecutor later withdrew the capital charge

- in some cases, you may find a document indicating that the prosecution waived the death penalty; in such cases the answer is "no" (unless the prosecution had previously formally requested the death penalty, in which case the answer is "yes")

- there may be some first degree murder cases where there is no documentary evidence one way or the other; in such cases, the answer is "no," unless the defendant pled guilty to first degree murder, in which case we will assume that the answer is "yes."

For the third and fifth questions in part three - "did capital charge go to jury?" and "did jury return pro-death verdict" -- the answer should be either, "yes," "no," or "not applicable." The second and fourth 
questions call for longer answers. If you need additional space, write "see comments" in the space provided and put your answer in the "comments" section.

Please be sure to get copies of documents, if possible, to show: (1) whether the prosecutor sought the death penalty, (2) whether a capital charge went to the jury, and (3) whether the jury returned a death verdict. In all cases where the prosecutor did seek the death penalty, there is a statutory requirement to provide the defense attorney a list of all aggravating circumstances the prosecution intends to prove at trial. Please make a copy of any documents that show the aggravating circumstances the prosecution charged.

\section{Part Four}

Include in part four any comments about unusual or interesting aspects of the case. 